NATALIA JOELSAS TIMERMAN

\title{
A LIBERDADE SEGUNDO SUA PRIVAÇÃO: \\ (IM)POSSIBILIDADES DO HOMEM NUM HOSPITAL PENITENCIÁRIO
}

(VERSÃO ORIGINAL)

\author{
Dissertação apresentada ao Instituto de Psicologia da Universidade \\ de São Paulo para obtenção do título de Mestre em Psicologia \\ Área de concentração: Psicologia Clínica \\ Orientador: Professor Doutor Andrés Eduardo Aguirre Antúnez
}

São Paulo, SP

2014 
AUTORIZO A REPRODUÇÃO E DIVULGAÇÃO TOTAL OU PARCIAL DESTE TRABALHO, POR QUALQUER MEIO CONVENCIONAL OU ELETRÔNICO, PARA FINS DE ESTUDO E PESQUISA, DESDE QUE CITADA A FONTE.

Catalogação na publicação

Biblioteca Dante Moreira Leite

Instituto de Psicologia da Universidade de São Paulo

Timerman, Natalia Joelsas.

A liberdade segundo sua privação: (im)possibilidades do homem num hospital penitenciário / Natalia Joelsas Timerman; orientador Andrés Eduardo Aguirre Antúnez. -- São Paulo, 2014.

$110 \mathrm{f}$.

Dissertação (Mestrado - Programa de Pós-Graduação em Psicologia. Área de Concentração: Psicologia Clinica) - Instituto de Psicologia da Universidade de São Paulo.

1. Liberdade 2. Prisões 3. Hospitalização 4. Fenomenologia I. Título.

BF621 
Nome: TIMERMAN, Natalia Joelsas

Título: A liberdade segundo sua privação: (im)possibilidades do homem num hospital penitenciário

Dissertação apresentada ao Instituto de Psicologia da Universidade de São Paulo para a obtenção do título de Mestre em Psicologia Clínica

Aprovado em:

Banca Examinadora

Prof. Dr. Instituição:

Julgamento: Assinatura:

Prof. Dr. Instituição:

Julgamento: Assinatura:

Prof. Dr. Instituição:

Julgamento: Assinatura: 
Ao meu filho, Benjamín. Meu começo. 


\section{AGRADECIMENTOS}

A Artur Timerman, meu pai. Pela paixão pelos livros e filmes, e por me oferecer o chão a partir do qual eu pudesse voar. A Martha Penna, pela conversa de vinho, de domingo, e por me ensinar a gostar de correr.

A Clarice Joelsas Haberkorn, minha mãe. Pela presença, e por ter me ensinado desde cedo a abraçar. A René Haberkorn, pela paciência, pela constância.

A Gabriela Joelsas Timerman, irmã e mais antiga amiga, sempre perto esteja em que canto do mundo estiver. A Vladimir Joelsas Timerman, pela semelhança, pela diferença.

Ao Demis Menéndez Sánchez: família.

Aos pacientes presos, que estão em todas as palavras e tanto me ensinam dos homens.

Ao Centro Hospitalar do Sistema Penitenciário, palco de tudo. A toda equipe de segurança e de enfermagem, por fazerem parte. À equipe do SAME, pelo bom humor diário.

A Lilian Ribeiro Caldas Ratto, pela oportunidade sempre renovada e pela constante compreensão.

A Tatiana Malavasi Sales, pelos olhos de ver o humano, mesmo quando tudo pede que não.

A Marcia Rodrigues Setubal, que chegou a tempo de me emprestar seu olhar que tanto já viu sobre detrás das grades - muito obrigada pela leitura e pelas preciosas sugestões.

A Jaqueline Hatsuko Tamashiro, Edneia Zanuto, Anne Maia e Camille Chianca, pela parceria, pelas trocas, por estarem sempre ali.

A Meire Florentin, pelo cuidado que nunca falta.

A Teresa Leopoldo e Silva, pelo convite primeiro e pelo aprendizado desde os corredores do Hospital São Paulo.

A Sandra Rodrigues, pela escuta amiga que acolchoa a dureza.

A Priscilla Spinola, pelas palavras que insistem quando o sentido escapa.

A Viviane Iziquiel, pela troca, pela dedicação.

A Ariana Zocaratto, a Cristiane Orsetti, a Alessandra Cursino de Oliveira, pelo sorriso, pela gargalhada, pelo olhar. 
Ao João Rafael Vieira de Moraes, pela escuta cheia de carinho. A Maíra Mendes Clini, pela irmandade de caminho. Ao Luis Jardim, pela chegada, pela eterna ajuda. A Marina Cecchini, pela amizade sempre cuidadosa. A Sheila de Marchi, por me mostrar os passos. A Alexandre Valverde, pelo início. A Cristiano Barreira, pelas palavras de liberdade.

A Ana Claudia Melcop, por estar tão perto, por me acompanhar os passos, por me ensinar a dançar a vida. A Patrícia Ottoni, pelo brilho, pela companhia, ladeira abaixo, ladeira acima. A Julia Teixeira Sperry Cezar, por tudo, tanto, sempre obrigada, amiga.

A Mariana Simas Magalhães, por me ler sempre de tantos jeitos. A Maria Laura Barretto, por atravessar comigo a vida. A Letícia Warde Borges, pelas viagens, pelas histórias, pelo tempo que foi e pelo que virá. A Mariana Cattel, porque tanto me conhece e me devolve a mim. A Thaís Cattel, por ser tão docemente ela. A Ana Carolina Chun Li, pela braveza mais querida do mundo. A Marina Colonelli, por nunca ter deixado de estar perto. Ao Renato Rosenberg, amigo de infância depois de adulto.

À Graça, ou Eulinda de Jesus: sem você me ajudando a cuidar do Benja e de mim, nem uma palavra teria sido escrita.

Ao Guto Pompeia, pela sabedoria sorridente e com brilho nos olhos.

Ao David Cytrynowicz, pela escuta infinita.

A meu orientador, Professor Doutor Andrés Eduardo Aguirre Antúnez, pela confiança, pelo apoio, pela ajuda e por me ensinar sempre outros jeitos de ver.

Aos membros da banca de qualificação, Professor Doutor Zeca Moura e Professor Doutor Gilberto Safra, pela leitura atenta, pelas sugestões tão enriquecedoras, por confiaram nas palavras que sejam minhas, por aguçarem meu olhar. Sua contribuição ultrapassa esta dissertação e abarca meus dias. Ao Zeca Moura, agradeço imensamente também pela oportunidade de conversa que despontou em reflexão profunda e ajudou a desfazer tantos nós. 


\section{RESUMO}

TIMERMAN, N. J. A liberdade segundo sua privação: (im)possibilidades do homem num hospital penitenciário. 2014. 110 f. Dissertação (Mestrado) Instituto de Psicologia, Universidade de São Paulo, São Paulo, 2014.

Esta investigação busca aproximar as vivências da privação de liberdade em pacientes detentos num hospital penitenciário e compreendê-las à luz da questão da liberdade segundo Hannah Arendt. Ela surge a partir da percepção da existência de muitas formas de se estar preso, além do que comumente se compreende como o encarceramento. Inicia-se com uma descrição fenomenológica do Centro Hospitalar do Sistema Penitenciário em que se busca compreender as peculiaridades deste lugar onde duas instituições complexas, o hospital e a prisão, se encontram; passa por uma aproximação das atividades do homem segundo Hannah Arendt (trabalho, obra e ação) no contexto do hospital penitenciário; e chega a narrativas de encontros entre a investigadora e quatro pacientes detentos, nos quais suas histórias e a maneira como vivem a privação de liberdade se acercam. Por fim, a partir de uma discussão teórica acerca da questão da liberdade, conclui-se, através dos encontros narrados e das transformações que a pesquisadora sofreu ao longo de dois anos de trabalho no hospital penitenciário, que a liberdade é restrita nesse contexto não como inicialmente havia se pensado, mas principalmente de outras maneiras. Se a liberdade é compreendida como o início de algo novo, acostumar-se à prisão significa sua restrição. A impossibilidade de encontro com o outro observada em pessoas que perpetraram alguns tipos de crime também impossibilita a liberdade enquanto ação entre os homens. Ainda assim, em situações muito específicas se pode avistar na prisão a possibilidade da ação que instaure o novo singular, principalmente quando a vida de quem está preso pode ser transformada numa história que se possa contar.

Palavras-chave: Liberdade. Prisões. Hospitalização. Fenomenologia. 


\begin{abstract}
TIMERMAN, N. J. Liberty according to its deprivation: (im)possibilities of men in a penitentiary hospital. 2014. 110 f. Dissertação (Mestrado) - Instituto de Psicologia, Universidade de São Paulo, São Paulo, 2014.
\end{abstract}

This study examines experiences of liberty deprivation by inmates in a penitentiary hospital through the prism of Hannah Arendt's question of liberty. It offers a broader scope of inmates' perception of their own imprisonment, beyond the usual understanding of incarceration as simply deprivation of freedom. The first part presents a phenomenological description of the Penitentiary System's Hospital Center, examining the peculiarities of this space, where two complex institutions, the hospital and the prison, meet. The second part explores Hannah Arendt's human activities (labor, work and action) in the context of the penitentiary hospital. The third part analyses the narratives of the encounter between the researcher, and her transformations over the two years conducting field research, and four inmates, in which their account and their experience of liberty deprivation come near. These clinical results examined within the elaborated theoretical framework clearly indicate that freedom, understood as starting something new, may actually take place in a prison, even if circumscribed.

Key-words: Liberty. Prisons. Hospitalization. Phenomenology. 


\section{SUMÁRIO}

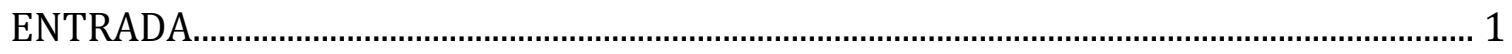

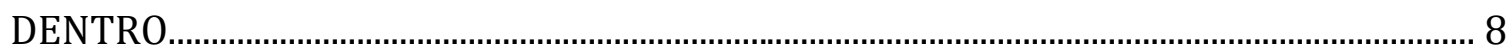

ATIVIDADE DO HOMEM, NO HOSPITAL PENITENCIÁRIO................................................ 35

O CAMINHO PARA PERTO DE QUEM ESTÁ DETRÁS DAS GRADES.....................................52

DIFICULDADES, IMPOSSIBILIDADES E SAÍDAS METODOLÓGICAS..................................................56

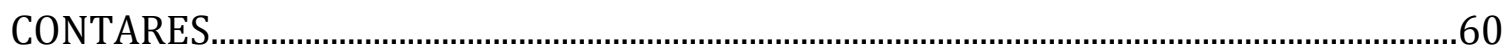

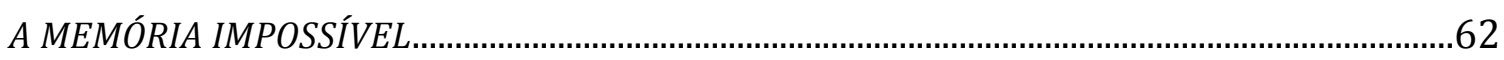

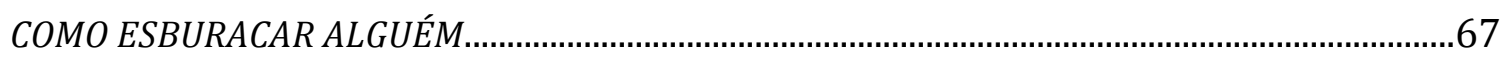

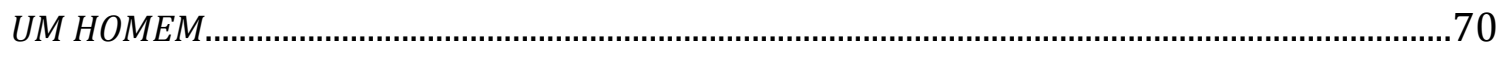

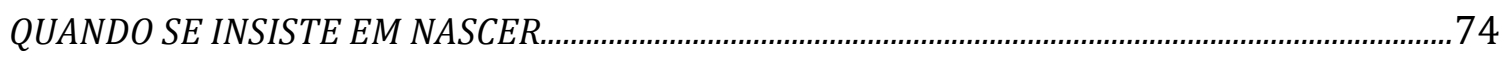

A LIBERDADE...............................................................................................................

HANNAH ARENDT E A LIBERDADE ..............................................................................

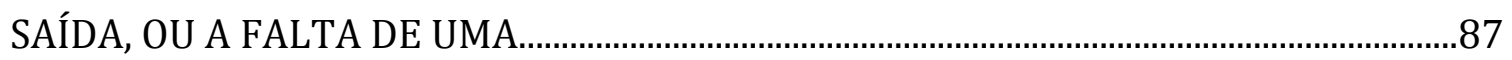

NO LUGAR DE UMA CONCLUSÃO.....................................................................................109

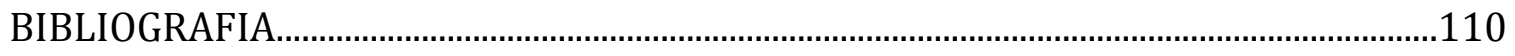

ANEXOS 


\section{ENTRADA}

Este escrito se inicia num fim e seus arredores: começa numa morte. Na morte de Álvaro ${ }^{1}$, de câncer, no leito de uma unidade de cuidados semi-intensivos de um hospital penitenciário. Precedida de muita dor, de alguma conversa, e enfim do silêncio.

Este escrito se inicia também numa gargalhada.

Quando comecei a trabalhar como psiquiatra no Centro Hospitalar do Sistema Penitenciário, o CHSP, Álvaro já estava no meio de seu fim. Ele foi das primeiras pessoas de quem pude me aproximar ali; presenciou meu olhar receoso do início, meus gestos contidos, o medo que eles denunciavam. Medo de que minha ingenuidade no trato com o mundo penitenciário aparecesse - e certamente aparecia; medo de que percebessem que eu não falava a língua da malandragem, que se me apresentava ali pela primeira vez (ainda não falo, e provavelmente nunca falarei, mas talvez chegue com o tempo um pouco mais perto de entendê-la); medo de que as pessoas que eu atendia, os detentos internados, pudessem me fazer algum mal. Porque nos primeiros dias de meu trabalho ressoava tudo o que eu havia escutado das pessoas que, como eu, não sabiam minimamente o que era trabalhar dentro da prisão, e que se assustavam um pouco do meu medo quando eu lhes contava o que iria começar a fazer. Não sabiam o que seria passar pela "revista" para entrar, atravessar diariamente o detector de metais, escutar o barulho das grades, sentir cheiro de hospital misturado ao que agora eu passava a conhecer como cheiro de prisão. Não sabiam, como eu, o que era a obrigatoriedade de atender de portas abertas aos detentos, sempre vestidos de calça bege e camiseta branca, sempre andando lentos, com os braços sempre para trás, a cabeça sempre baixa, o olhar sempre mirando o chão. Como eu, não sabiam que, diante de tudo isso, existe o risco de nos esquecermos de que quem está por detrás daqueles gestos todos, obrigatoriamente mais contidos que os meus, são pessoas. Como eu.

\footnotetext{
1 Nome fictício. Todos os nomes que se seguirão são fictícios.
} 
Amenizado o receio inicial de que eu pudesse ser agredida fisicamente, desrespeitada sexualmente, ter minha vida imediatamente ou fora dali ameaçada, percebo agora - passados dois anos nos quais fui inicialmente duas, e depois três vezes por semana, além de um final de semana por mês, ao CHSP - haver atravessado inicialmente um certo encantamento com a prisão. Depois de perceber que meus medos não se configuravam como perigos constantes e iminentes houve espaço, então, para esse encantamento, que consistia na descoberta óbvia e simples, mas grande, de que aquelas pessoas eram pessoas. Os poucos momentos de conversa com Álvaro foram suficientes, por exemplo, para que eu percebesse que, de início, eu precisaria me desvencilhar dos meus próprios preconceitos se quisesse tentar compreender o que se passava dentro daquele hospital-prisão: os meus preconceitos não condiziam com aquela gente que podia me contar sua história. Através da maneira como Álvaro me oferecia a sua, que talvez pela suspeita tácita da proximidade do fim era a um só tempo ávida de escuta, prenhe de possibilidades de compreensão, viva e, embora dolorosa, bela, ele me possibilitou enxergar que as histórias das pessoas que se encontravam presas ultrapassavam imensamente a noção equivocada do senso comum de que todos ali eram bandidos sem sentimentos e que o lugar deles deveria ser mesmo aquele; a maneira como ele me oferecia sua história me possibilitou enxergar que era todo um encadeamento único de fatos, em forma de uma trajetória, o que levava cada um a estar ali. Estar preso era como a confluência de muito específicas decisões, acasos e destinações e por isso um momento que, sob um aspecto, me pareceu inicialmente ser privilegiado: o aspecto da possibilidade de reviver a própria história, tecendo com ela uma possível narrativa da própria vida (ainda que me fosse extremamente custoso e eu soubesse absurdo caracterizar como privilegiado, em qualquer aspecto, o fato de se estar preso). Quando o fato tão óbvio, mas tão esquecido, de que aquelas pessoas presas continuavam a ser gente com história própria deixou de me surpreender, o encantamento inicial com a prisão, que agora me parece até absurdo, sumiu. Não era com a prisão que eu me encantava, mas com o fato de encontrar pessoas onde nunca soube que as houvesse. 
Álvaro, doente, revivia sua vida através dos novos sentidos que aquele contar parecia lhe possibilitar. Um dos acontecimentos que ele recorrentemente trazia era a morte do pai, que ocorrera quando ele já estava preso e por isso não pudera acompanhar. Ele falava daquela morte, ocorrida havia anos, com dor muito mais pungente que a dor de estar cotidianamente distanciado do mundo pelo fato de estar preso. A especificidade daquela pungência fez com que eu começasse a suspeitar de que dentro da prisão existem muitas formas de se estar preso. Foi escutando Álvaro que me apareceu pela primeira vez que estar encarcerado, fora do mundo, era em alguns momentos difícil mais que pelo cotidiano restrito, mas pelo distanciamento dos grandes acontecimentos das pessoas queridas: seu nascimento e sua morte. Álvaro contava do câncer do pai aproximando, assim, sua história da dele; e o emocionar-se ao reviver a dor de não ter estado próximo quando o pai morreu parecia ser a primeira, senão a única, possibilidade de culpa, como se fosse aquela dor a conexão entre os acontecimentos de sua vida e aquele momento, entre o encadeamento de fatos que levou a seu crime e a sua verdadeira pena. 0 mesmo brilho doloroso eu via já em atendimentos a outras pessoas, nos olhos dos que tinham sido pais enquanto estavam presos, e semelhante à dor de até então não conhecer os filhos era a dor de não os ter podido ver surgir.

A prisão, como o que acaba por excluir homens do mundo comum, mantendo-os "isolados dos seus familiares e companheiros, (...) inativos, e, desta forma, desmantelados no plano existencial" (NAFFAH NETO, 1985, p. 26), como o que tenta igualar o que é plural - através das mesmas vestimentas brancas e beges dos uniformes com que os detentos são obrigados a se vestir, da postura cabisbaixa com que devem percorrer os corredores, da ausência de quase todos os seus pertences, para falar do que primeiramente salta à vista, aparece como a tentativa de extrair o homem da história no próprio mundo ao qual ele, no entanto, continua conectado através da possibilidade - ou realidade - da vida, através do nascimento e da morte. 0 igual da roupa, o igual da falta de pertences, a falta de acesso ao fora me despontavam agora como tentativas reiteradas de calar o humano em cada pessoa ali e assim e somente por isso, privá-las do que comumente se entende por liberdade. Não cabe aqui uma discussão com respeito à validade de tal maneira de 
penitenciar alguém que cometeu qualquer tipo de delito, nem se isso se faz uma resposta coerente, proporcional ou lógica como pena diante do que é julgado como crime. Cabe sim dizer que as maneiras de se estar preso na prisão me pareceram muito mais complexas, dizendo muito mais do humano do que eu supus ao pisar ali pela primeira vez, assim como as maneiras de se achar livre dentro da prisão - como meu encantamento inicial me fez vislumbrar, qual uma planta que achasse brecha no concreto para surgir.

E a gargalhada? Esta veio um pouco depois, numa manhã qualquer, se é que existe um "qualquer" no lugar para onde tantas histórias confluem. Eduardo estava internado na ala psiquiátrica do CHSP e encontrava-se francamente psicótico. Pulava de uma ideia a outra, todas grandiosas: tinha chegado ali através do Titanic, na verdade era Jesus, mas dessa vez tinha vindo como ladrão, e podia transformarse na Anaconda. Naquela manhã ele me disse que era o Aladim. Não sei exatamente por que justamente com o Aladim me foi inevitável deixar escapar a mais sonora das gargalhadas. Ele riu junto, compreendendo e compreendido; e para provar que era de verdade o Aladim, saiu pulando numa perna só, enquanto eu ria mais, junto com ele, que pulava e ria. De alguma maneira Eduardo estava me dizendo quem era naquele momento: um personagem de si mesmo, fictício e anacrônico; e a minha gargalhada, pela própria espontaneidade, talvez o tenha liberado para ir mais longe e dizer-me mais de si e dos presos, e dos homens, através de seu gesto: alguém que tem uma perna a menos, erra o personagem que escolheu para a própria vida, mas consegue pular, gargalhando, absurdo entre aquelas paredes e grades, transbordando vida onde só deveria ser permitido definhar - a prisão. Eduardo estava preso, psicótico e internado; poder-se-ia dizer que estava triplamente preso. No entanto, seu gesto absurdo, legitimado pelo absurdo da minha gargalhada, parecia livre. Eduardo, preso em três instâncias, mostrava-me que o oposto ao aprisionamento não é necessariamente a liberdade, pois esta talvez possa se fazer presente mesmo quando se está encarcerado, existindo onde se der o que é humano no homem.

Assim surgiu para mim, somando-se ao que trouxe a história de Álvaro e seu contar, a indagação a respeito da relação do aprisionamento com a liberdade: de que 
forma estar encarcerado, preso, o que comumente se denomina como estar "privado de liberdade", verdadeiramente "priva" a liberdade? É de liberdade que se fala quando se posta tal questão? Quais as diferentes maneiras de aprisionamento que se explicitam na prisão e mais especificamente no hospital penitenciário? Neste caso, em se tratando de uma prisão que é também hospital, ainda mais "possibilidades de impossibilidades" surgem, pois o adoecer no sentido de privação também é aprisionamento e sempre é uma possibilidade do homem através da retração de seu poder-ser. "A doença é um fenômeno da privação", aponta Heidegger (2001, p. 73). Seria possível responder a essas questões aproximando-me da fala das pessoas que vivenciam, de fato, o encarceramento? 0 que o encarceramento e o aprisionamento em suas diferentes manifestações podem dizer a respeito da liberdade? 0 que é, afinal, a liberdade?

Quando comecei a trabalhar no CHSP, no início de 2012, coincidentemente lia A Condição Humana, de Hannah Arendt, e coincidentemente havia recém ingressado no mestrado, com um projeto acerca de pessoas com diagnóstico de transtorno de personalidade borderline. Tais coincidências se revelaram rapidamente no mínimo uma grande sorte, porque a riqueza (e beleza, ouso dizer, amparada pelo meu encantamento de então e pelo que escutei em aula do professor José Moura Gonçalves Filho: beleza é aparição) do que eu presenciava em meu novo trabalho no hospital penitenciário parecia se traduzir no que eu lia, escrevendo perguntas incessantes numa linguagem para mim completa e duplamente nova: a da prisão e a da liberdade. Não me vi com outra alternativa senão mudar completamente o projeto que eu tencionava fazer ao ingressar no mestrado. As questões, aquelas ditas anteriormente acerca do aprisionamento e sua relação com a liberdade, despontavam na questão da liberdade que me aparecia em Hannah Arendt.

Não encontrei na literatura uma investigação que se propusesse a pensar a liberdade segundo sua privação no contexto do encarceramento e do adoecimento. Quando algo nos falta, a sua ausência de alguma maneira sublinha, amplia a presença do que falta e por isso me parece legítimo e importante pensar a liberdade a partir e através de sua privação. 
Para tentar realizar a aproximação do que aparece como privação de liberdade para internos ${ }^{2}$ de um hospital penitenciário tanto por estarem presos quanto por estarem adoecidos, esta investigação trará relatos de encontros entre mim e quatro pacientes detentos em que conversamos sobre suas vidas e nos quais tento me acercar da maneira como eles vivenciam a privação de liberdade. Trilharei um caminho até estes relatos que se inicia nesta "Entrada", seguido do traçado de uma descrição do hospital penitenciário em "Dentro" - para que o onde do que se vai contar já possa ser visto por quem está lendo. Após, em "Atividade do homem, no hospital penitenciário" faço uma tentativa de compreensão de alguns aspectos da atividade humana segundo Hannah Arendt no contexto do aprisionamento, acercando-nos um pouco mais da questão da liberdade. Em "O caminho para perto de quem está detrás das grades", aprofundarei o percurso metodológico trilhado por mim para chegar aos relatos e colhê-los - o método fenomenológico, utilizado também na realização da descrição do CHSP. Apresentarei, então, os "Contares" das quatro pessoas que me falaram acerca da liberdade. Após, farei um breve apanhado teórico sobre a questão da liberdade, principalmente segundo Hannah Arendt, que me auxiliará na seguinte discussão acerca dos relatos em "Saída, ou a falta de uma". Por fim, apresentarei o que este caminho me permitiu concluir.

Já que passou meu encantamento inicial com a prisão, posso tentar agora entender melhor seu significado, além da surpresa de me deparar com pessoas ao invés de personagens dos meus próprios preconceitos. A prisão parece, sob alguns aspectos, poder dizer dos homens coisas que o viver comum e cotidiano não conseguem dizer. Steinhardt, que viveu anos de sua vida preso, nos fala sobre isso:

A lição da prisão é uma lição de realismo. As instituições humanas, as doenças humanas, os caracteres humanos, os sistemas políticos ou sociais podem ser decifrados melhor nos momentos de crise. A situação limite que a prisão representa

\footnotetext{
${ }^{2}$ Ao escrever esta pesquisa deparei-me com a dificuldade de definir como chamaria quem está preso e internado: se "interno", de acordo com a definição de quem vive numa instituição total segundo Erving Goffman em Manicômios, prisões e conventos; se "paciente detento", ressaltando o aspecto da internação ao invés do da prisão, ou se "detento internado", fazendo sobressair o aprisionamento. Como a ênfase da pesquisa recaiu sobre a prisão como privadora de liberdade e não sobre o hospital, prevaleceu detento internado, porém foram utilizados também "interno" e "paciente detento" em alguns momentos em que me pareceu importante ressaltar os aspectos sublinhados por cada expressão ou quando a escrita o pedia, como parece ser o caso acima.
} 
ajuda-nos a vermos as coisas elementares, esfumadas pelo ritmo normal da passagem do tempo. A prisão é um contato imediato com as infraestruturas, deixando muito atrás o marxismo e a psicanálise, com reputação de verdadeiros caminhos de penetração da profundeza e de verdades finais. Como parecem de salão o marxismo e o freudismo, quão polidos, quão borboleteadores em comparação com a seriedade da prisão. (2009, p. 353)

Tentarei olhar então para a seriedade da prisão para descobrir se nela pode despontar a liberdade.

Assim se apresenta e começa esta investigação. E se começa numa morte, é porque começa depois do fim. Algo como a prisão: o que se inicia quando tudo terminou. Marginal também do tempo, o preso é aquele que, nas histórias, não aparece na última cena, porque o desfecho do enredo principal conta com sua exclusão. Aqui convido a darmos um passo em direção ao depois, ao depois de tudo, ao que vem quando a história termina. Para quem está preso há que viver o começo depois do fim. 
DENTRO

Dentro do muro nem tão alto coroado de grades e arames, que do lado de fora, através de pichações de dizeres como "100\% funk vida loka", "big jhou M" e tantos outros impossíveis de se ler, mira para um conjunto habitacional popular, está um mundo à parte.

Ao lado da entrada, pichado às pressas, meio torto e inacabado, o yin yang um dos símbolos do Primeiro Comando da Capital, o PCC. Passei por ali por quase um ano até que pudesse percebê-lo, apesar de que certamente já estivesse desenhado desde bem antes de minha chegada.

Trabalho como psiquiatra no Centro Hospitalar do Sistema Penitenciário, no bairro do Carandiru, em São Paulo, desde janeiro de 2012. Não se trata de um dos três Hospitais de Custódia e Tratamento Psiquiátrico do Sistema Penitenciário do Estado de São Paulo. Trata-se do único hospital geral para atender às demandas de saúde - clínicas, cirúrgicas ou psiquiátricas - através de assistência hospitalar e ambulatorial, da população carcerária das 151 Unidades Prisionais do Estado (segundo http://www.sap.sp.gov.br ). Tem 375 leitos distribuídos em quatro alas de internação, com dois andares cada (segundo http://www.santacasasp.org.br ).

Faço parte da equipe de Saúde Mental, composta por outras cinco psiquiatras, quatro psicólogas e três terapeutas ocupacionais. Todas mulheres. A maioria no CHSP desde que a Irmandade da Santa Casa da Misericórdia de São Paulo iniciou a parceria de gestão com o Governo do Estado de São Paulo, em 2009. Atendemos, subdivididas em miniequipes, aos pacientes da ala psiquiátrica e às demandas de interconsulta dos pacientes internados pelas outras especialidades (clínica médica, cirurgia, fisiatria, infectologia) e das puérperas. Realizamos também atendimento psiquiátrico ambulatorial.

Desde as redondezas do CHSP já se fazem ver e ouvir as ambulâncias e os "bondes"3, pequenos caminhões nos quais são transportados os detentos, ambos

\footnotetext{
${ }^{3}$ Apresentarei as expressões comumente usadas na prisão entre aspas, mas assim que esclarecido seu significado as deixarei sem as aspas para uma melhor fluidez do texto, ainda que me custe não mantê-las quando têm tonalidade pejorativa (caso de "gaiola" ou "origem", por exemplo).
} 
sempre escoltados, movendo-se tão velozmente como se carregassem carga explosiva. Apesar das grades e arames ao alto, o portão de entrada está sempre aberto. Fechados estão tantos outros que se seguem.

A primeira parte do estacionamento, com a qual me deparo logo ao atravessar o portão, é sempre movimentada. Um trânsito frequente de viaturas de polícia, ambulâncias e bondes, muitas vezes dificultando a passagem dos carros, gerido por homens fardados e armados que tentam organizar tantos veículos num espaço tão pequeno, antecipa peculiaridades do mundo em que a cada dia se adentra ao atravessar os portões, revistas, detectores, grades. Paro o carro numa das concorridas vagas, nos próximos dois pátios de estacionamento, disputadas pelas equipes de saúde, administrativa e de segurança. No carro, fica a bolsa com carteira, telefone celular e tudo o que não será usado nas horas de trabalho, ou que não é permitido do lado de dentro das grades todas - caso do telefone celular. Para quem não vai de carro, há armários com cadeados logo na entrada onde deixar os pertences proibidos de entrar.

Para chegar até à primeira revista, contorno por fora arames que alcançam alto. Quase tão alto quanto as árvores, do lado de dentro e do de fora dos arames, nas quais cantam pássaros. Canto normal de pássaro, de manhãs comuns. Um comum que contrasta, sublinhando, com as armas dos homens fardados que já posso ver numa torre de segurança, mais altos que as árvores e os pássaros, garantindo o fechado daquilo, garantindo que o fora é fora e que o dentro é dentro, vigiando, guardando quem não pode sair, como histórias que tivessem que permanecer caladas, abafadas pelas portas todas.

Pela pequena abertura retangular na porta de ferro, sou vista por alguém que a abrirá para mim. Esta função, a de abrir a porta, quase nunca me cabe (ou é permitida) a partir de então. Uma funcionária me faz a revista inicial, diante de um sorriso e de um bom dia. Tão comuns quanto o canto dos pássaros. Peito, cintura, bolsos, pernas.

Lembro-me do dia em que fui conhecer o Centro Hospitalar do Sistema Penitenciário para talvez começar a trabalhar ali. Um pouco assustada, entreguei o documento que confirmava que eu era a mesma que constava no papel de 
autorização para entrar e passei por cada um dos procedimentos de segurança estranhando tanto como se me fosse eternamente impossível acostumar com aquilo. Eu ainda não sabia que algumas peças de roupa "apitavam" nos detectores de metais, muito mais sensíveis que aqueles pelos quais eu já havia passado nos aeroportos: botão de calça, relógio, alguns brincos, grampos, arame de sutiã, sola de alguns sapatos. Tampouco sabia que a bolsa que carrega diariamente meu jaleco, caneta, prancheta, carimbo, tem que ser transparente mesmo que vá atravessar, ao mesmo tempo em que eu o detector, o raio X. Tudo o que entra deve ser controlado.

Eu ainda não sabia o que era uma "instituição total" 4 embora estivesse prestes a adentrar uma delas; sabia muito menos que um lugar assim, cujo caráter fechado e total "é simbolizado pela barreira à relação social com o mundo externo e por proibições à saída que muitas vezes estão incluídas no esquema físico - por exemplo, portas fechadas, paredes altas, arame farpado (...)" (GOFFMAN, 2013, p. 16), implica em privações específicas e transformações geralmente adaptativas em quem vive ou trabalha lá. Impossível entrar e sair sem ser marcado.

A primeira portaria é separada do acesso às equipes ao hospital por um pátio por que passam as ambulâncias e os bondes e onde, na sombra de algumas árvores, há bancos de descanso, conversa e cigarro - para os funcionários, não para os detentos. Estes entram através de um portão específico atrás do qual se dá a "inclusão" (revista, troca de roupa para que todos usem o uniforme do CHSP e recepção do prontuário) e ficam restritos às alas guardadas atrás de inúmeros portões e trancas. O CHSP quase nunca é o destino primário de quem está adentrando o sistema penitenciário, e talvez por isso a inclusão não costume ser tão

\footnotetext{
${ }^{4}$ Goffman caracteriza da seguinte forma as instituições totais, das quais são exemplo os manicômios, os conventos, os quartéis e as prisões: "O aspecto central das instituições totais pode ser descrito como a ruptura das barreiras que comumente separam essas três esferas da vida [dormir, brincar e trabalhar]. Em primeiro lugar, todos os aspectos da vida são realizados no mesmo local e sob uma única autoridade. Em segundo lugar, cada fase da atividade diária do participante é realizada na companhia imediata de um grupo relativamente grande de outras pessoas, todas elas tratadas da mesma forma e obrigadas a fazer as mesmas coisas em conjunto. Em terceiro lugar, todas as atividades diárias são rigorosamente estabelecidas em horários, pois uma atividade leva, em tempo predeterminado, à seguinte, e toda a sequência de atividades é imposta de cima, por um sistema de regras formais explícitas e um grupo de funcionários. Finalmente, as várias atividades obrigatórias são reunidas num plano racional único, supostamente planejado para atender aos objetivos oficiais da instituição." (2013, pp. 17-18)
} 
marcante quanto a que acontece nas unidades prisionais em geral ${ }^{5}$. Para o CHSP vão internos que já estejam em outras unidades prisionais e que tenham demandas de saúde (clínicas, cirúrgicas ou psiquiátricas) para atendimento ambulatorial ou internação. Todos já sabem, ou deveriam saber, as regras da prisão; precisam, se ficarem internados, entender as rotinas do hospital. Há poucos casos de gente que vem direto de um hospital "da rua", como são qualificadas todas as coisas que não pertençam ao mundo prisional. Para estes o CHSP é o primeiro contato com todo um complexo conjunto de regras explícitas ou implícitas ao qual eles inevitavelmente terão que se sujeitar.

Os internos chegam e saem do CHSP de ambulância, individualmente, ou de bonde, em bando. Sempre escoltados. Os bondes são pequenos caminhões cuja parte traseira, completamente fechada, exceto por pequenos furos espalhados para a entrada de ar, serve para transportar - como carga - vários detentos juntos, seja qual for o tipo de doença que os leva ao hospital, contagiosa ou não. Inúmeros são os relatos de gente que vomita naquele espaço quente, pequeno e escuro. Inúmeros são os relatos de gente que vomita com nojo do cheiro que já estava ali, tornando-o ainda mais asqueroso. Inúmeros são os pedidos dos detentos para que os atendimentos ambulatoriais sejam mais espaçados, porque eles vem de longe, o que significa horas dentro do bonde (o tempo, por exemplo, de uma viagem de Ribeirão Preto a São Paulo). Quando está sol e o bonde fica estacionado, esquentando ainda mais aquele amontoado de gente que carrega, os internos, enquanto esperam a inclusão, chegam a gritar, tão insuportável é permanecer ali dentro.

Apesar de bem mais frequente, o trajeto de chegada das equipes de saúde, segurança, manutenção e administração ao CHSP é bem mais tranquilo que o dos internos: não temos que passar pela inclusão e a entrada é sempre, no final do dia, complementada pela saída.

Uma marca em amarelo no chão me indica o caminho pelo pátio até o edifício do hospital. Após a porta, outra passagem por detector de metais onde, como na anterior, no horário de entrada se forma uma fila de gente que precisa tirar sapato,

\footnotetext{
${ }^{5}$ Para acessar uma descrição e compreensão das marcas deixadas pela entrada numa prisão (como em qualquer instituição total), consultar Goffman em Manicômios, prisões e conventos, pp. 23-83.
} 
grampo e relógio, enquanto uns dois seguranças, geralmente um homem e uma mulher, nos assistem do outro lado de um balcão. Bom dia e sorrisos.

Depois do corredor do setor administrativo atravesso uma sala que dá para o primeiro dos muitos outros portões de grade de ferro, constantemente trancado e acompanhado de um agente de segurança penitenciário, ali conhecido como "ASP". 0 corredor que se segue, de onde saem outros, com suas paredes verde claras, se não fosse o ecoar do portão de grade de ferro que acaba de ser trancado logo atrás, diria que vou adentrar apenas um hospital, com seu cheiro característico e seus personagens habituais transitando de jaleco. Mas para, entrando à direita, seguir para o chamado corredor psicossocial (onde ficam as salas da assistência social, as salas de atendimento, uma pequena biblioteca de porta sempre fechada e o setor de saúde mental, e que é acesso das equipes às alas), preciso atravessar outro dos portões de grade de ferro, desta vez guardado por uma ASP. É ela quem cuida da chegada dos pacientes ao corredor para serem atendidos (através de uma lista feita por quem vai atender em outras duas vias além da que vai para as mãos dela - a via da segurança da ala do paciente e a da enfermagem), aloca-os nas salas, chama a profissional que solicitou o atendimento e, de tempos em tempos, passa pelo corredor, olhando para dentro das salas - que não devem ter as portas fechadas, mesmo (e principalmente) durante os atendimentos. Durante eles, para quem olha da porta, o paciente fica de costas e quem o atende, de frente, separados por uma mesa. É a ASP também quem apressa o paciente, finda a necessidade de sua permanência ali, para que não se demore em observar ou falar com pessoas da equipe ou outros detentos.

Os horários de atendimento são divididos: antes das 10 horas, apenas podem ser atendidas as mulheres, das alas C e D, de enfermaria e celas-leito a primeira, e de puérperas a segunda. É comum então ver mulheres carregando os recém-nascidos filhos, cujo choro ecoa junto com o ecoar das batidas dos portões. Misturados sons. Após às 10 horas só podem ser atendidos os homens, que ficam nas alas A e B. A primeira é composta pelo setor de internação psiquiátrica, pela clínica médica e infectologia e a segunda pela cirurgia e fisiatria - ambas por muitas celas e uma ou duas enfermarias. Homens e mulheres sempre separados. Houve uma mulher, 
interna da ala $\mathrm{D}$, puérpera com filho no colo, que soube através de sua família da morte do pai de seu filho. Uma história comum de se escutar ali, não fosse o fato de que ele falecera a poucos metros de onde ela estava, na unidade de cuidados semiintensivos. Sem que um soubesse da proximidade do outro.

Ainda no mesmo corredor, à direita, está a sala de atendimento em grupo de terapia ocupacional em saúde mental. Logo após ficam as três salas em que se organiza o SAME, Serviço de Arquivo Médico e Estatística, cuidando dos prontuários, encaminhamentos internos e externos, agendamentos e avisando as unidades prisionais de origem para que façam a remoção dos pacientes após sua alta. Entre outros dois portões de ferro, duas salas, uma diante da outra, com estantes de prontuários dos pacientes internados e computadores onde se faz a prescrição médica. Não fossem os portões e a passagem frequente dos pacientes detentos, caracteristicamente vestidos e guardando sempre na postura a cabeça baixa e os braços para trás, apenas coisas de um hospital comum.

A partir do corredor que se segue a impressão de estar num hospital comum já não me visita mais. É um corredor mais amplo que todos os anteriores, demarcado, em uma das laterais, com uma faixa amarela que delimita o estreito espaço por onde podem transitar os detentos. Em ambas as extremidades - a da direita das alas A e B, masculinas, e a da esquerda, das alas C e D, femininas -, detectores de metal por onde passam todos os que entram nas alas, detentos ou funcionários.

Dentro do espaço delimitado pela faixa amarela, transitam homens e mulheres (uns ou outros, dependendo do horário, como explicado acima), vestidos de camiseta branca e calça bege - cor esta proibida no vestuário de quem trabalha lá, para que não se confundam os que permanecem e os que entram e saem diariamente. Cada peça de roupa é marcada com a sigla do hospital. Nos pés, sempre chinelos: na prisão este é o único calçado, faça frio ou calor. Os homens de cabelo cortado e barba feita. Mãos para trás e cabeça baixa. Se levantam o olhar ou soltam as mãos, não tarda um pedido pouco amigável de algum ASP, sempre à espreita, para que aquela posição seja reassumida.

Segundo nos diz Goffman, 
No idioma expressivo de determinada sociedade civil, alguns movimentos, algumas posturas e poses traduzem imagens inferiores do indivíduo e são evitadas como aviltantes. Qualquer regulamento, ordem ou tarefa que obrigue o indivíduo a adotar tais movimentos ou posturas, pode mortificar seu eu. $(2013$, p. 30$)$

Postura cabisbaixa, com passos lentos e mãos juntas atrás - uma das inúmeras maneiras para que não se esqueça onde se está: um lugar onde as regras devem ser seguidas. Um lugar - aprende-se com o tempo - em que algumas regras devem sempre ser seguidas e outras também, mas todas nem sempre o são. Um lugar que existe não em prol dos que lá estão, mas em prol dos que lá não se encontram - já que a prisão serve primordialmente para proteger a sociedade de quem lhe pode oferecer perigo. A prisão: um lugar destinado a pessoas porém cuja intenção principal não é o seu bem estar. Diferente do hospital, cuja intenção deve ser justamente o bem estar que a prisão desdenha.

Além do corpo, a fala também precisa respeitar um jeito exigido pela instituição e que desrespeita a maneira natural, individual, com a qual cada um se expressa. Entre os internos, uma linguagem comum, tampouco individual ou pessoal: gírias que não traduzem o jeito que cada um tem de falar, e se o fazem, é porque o jeito que deveria ser pessoal há tempos não existe, se é que chegou a se configurar. Entre os internos e os ASPs (e também a equipe médica), de um lado, uma deferência incômoda e forçada, de outro expressões que variam entre o desleixo, o deboche, a reafirmação de autoridade ou, na melhor das hipóteses, um respeito distante. Quanto à maneira com que os internos devem tratar os ASPs, nos diz Goffman que há um

(...) padrão de deferência obrigatória (...); muitas vezes, os internados são obrigados a, em sua interação social com a equipe diretora, apresentar atos verbais de deferência - por exemplo, dizendo "senhor" a todo momento. Outro exemplo é a necessidade de pedir, importunar ou humildemente pedir algumas coisas pequenas - por exemplo, fogo para cigarro, um copo d'água (...). (2013, p. 30)

Mesmo os internos que estão ali apenas para atendimento ambulatorial e devem ir embora no mesmo dia (o que nem sempre ocorre, pois depende da disponibilidade do bonde da unidade de origem e da escolta) sabem das regras do 
corpo, da fala e da necessidade de pedir para que suas necessidades mais básicas sejam atendidas. Estes, de estadia mais transitória, distinguem-se dos pacientes internados por vestirem-se inteiros de amarelo - cada peça de roupa sempre marcada com a sigla do hospital.

Por baixo das vestes, muitas tatuagens, estas sim impossíveis de serem tomadas quando da entrada da pessoa no sistema carcerário. Grandes, pequenas, coloridas, guardam, muitas, significados específicos que são parte de todo um código, uma linguagem que quem é preso pela primeira vez precisa logo começar a aprender. Algumas feitas na rua, outras de improviso na prisão, com caneta e agulha; algumas desejadas, outras impostas por outros presos para avisar simbolicamente ao mundo da prisão de que tipo de crime seu dono foi autor. Nomes, rostos, times de futebol, armas, santos, símbolos de status no crime: tantas histórias escondidas por detrás das roupas.

Na parte central do corredor em cujas extremidades ficam as alas está a unidade de tratamento semi-intensivo, ou simplesmente semi. Lá os internos, tão debilitados, muitas vezes usam apenas fralda, deixando à mostra as tatuagens tão contrastantes com seu estado atual. Toda uma aura de medo ronda aquele recinto em que se veem frequentemente pessoas jovens e esqueléticas, desmembradas, intubadas, inconscientes, mas também quem se recupera por horas ou poucos dias de alguma cirurgia realizada no centro cirúrgico, ali ao lado. Gemidos lançados num ar putrefato, com cheiro de pus, fezes, suor e morte ${ }^{6}$. Tantas vezes escutei, com voz de pavor, dos pacientes que relutavam em ser transferidos para aquele temido setor o argumento de que todo mundo que vai para lá morre. Ali, não se fuma. Nas outras alas todas, sim. Ali não há visita íntima7 ${ }^{7}$ e quem vem visitar não pode sentar nem na cama. Outros motivos para que a semi seja tão odiada.

\footnotetext{
${ }^{6}$ Tal descrição, ainda que impactante, se refere ao ambiente de qualquer unidade hospitalar de cuidados intensivos ou semi-intensivos, onde há a presença constante da morte e seus odores, não havendo relação das características mostradas com o fato do CHSP ser também uma prisão, exceto pelas tatuagens e pelo fato de a maioria dos pacientes ser jovem.

${ }^{7}$ A "visita íntima", momento de intimidade sexual do interno com quem o vem visitar, não é algo estabelecido pelas regras institucionais porque o CHSP é um hospital, mas é algo dado pelas regras tácitas de quem vive na prisão e, mesmo que proibida pelo hospital, acontece em todos as alas exceto na semi.
} 
Ao lado da semi, o centro cirúrgico do hospital, onde se realizam cirurgias pequenas e médias. Do lado oposto à semi-intensiva, um pouco mais adiante está o corredor do ambulatório, com seu respectivo "seguro"8 adiante. Ao entrar neste corredor dois pequenos espaços gradeados conhecidos como "gaiola" costumam abrigar por manhãs e tardes inteiras uma quantidade enorme de homens trajando amarelo, aguardando a vez de serem atendidos. Amontoam-se nas grades na tentativa de ver a pequena televisão ao alto alguns metros à frente. Todos usando máscaras simples para evitar a possível (e provável) transmissão de tuberculose (apesar de que a proteção contra o contágio é feita com outro tipo de máscara, à qual somente as equipes de saúde e segurança tem acesso, e que é fornecida uma vez por mês, mediante uma solicitação específica. É uma máscara cara.). Dois ou três ASPs ficam ali, à espreita, tentando reduzir a comunicação entre eles e os internados que porventura passem para atendimento de reabilitação de fisioterapia ou terapia ocupacional, numa sala grande e bem equipada mais ao fim do corredor.

Logo que comecei a trabalhar no CHSP, passava ao lado da gaiola, dava bom dia, sempre escutava os frequentes chamados para os mais variados pedidos e sempre que possível os atendia. Doutora! Senhora! A senhora me arranja um cigarro? Estou com dor de cabeça! Chama a assistente social?... Com o tempo, deixei de olhar para o lado para fingir não perceber aqueles trinta pares de olhos me olhando, e não sei se eles deixaram de me pedir todas aquelas coisas ou se fui eu quem os deixou de escutar.

Nos extremos do corredor, guardadas sempre por uns três ou quatro ASPs, homens à direita e mulheres à esquerda (também os ASPs se dividem em gênero conforme os internos que devem vigiar), ficam as alas onde se localizam as celas e enfermarias. Para entrar nelas para atendimento, após passar pelo terceiro detector de metais, é necessário esperar que me abram mais um portão de grade de ferro, trancado sempre com um enorme cadeado. A entrada para visita médica só é permitida após às $8 \mathrm{~h}$, e sempre acompanhada de um ASP. Do portão já se avista um banco de concreto junto à parede, quase o único lugar para se sentar. Em toda a

\footnotetext{
${ }^{8}$ A definição de "seguro"será dada mais à frente.
} 
parte do CHSP reservada aos internos não há cadeiras ou mesas, nem para as refeições, exceto por dois conjuntos de uma mesa acoplada a cinco bancos de cada lado, um na enfermaria de psiquiatria, um na ala D, das puérperas. Na enfermaria de psiquiatria a mesa é utilizada para as refeições quando a tranca está aberta, mas na ala D há muito mais puérperas do que oito bancos poderiam abrigar e as refeições costumam ser feitas com a marmita no colo, cada uma sentada em seu leito, como no resto do CHSP.

Logo ao entrar na ala chega-se a um pequeno pátio de muros altos, sujos e descascados, coberto por um teto de arame através do qual passa a iluminação do sol. Tudo é branco, cinza ou bege, exceto as portas das celas, que são azul escuras. Lembro-me de um paciente que guardava uma folhinha muito pequena, mas verde, que o vento trouxera pela janela da cela, no alto. Ele a guardava como a visita concentrada de tudo o que não lhe cabia ali. Recebera um grande presente, e o mostrava nas mãos como uma pérola.

Após às 10 horas abrem-se as trancas e os pacientes podem sair de suas celas e transitar por ali, exceto os do "seguro", que às 10 horas são trancados para sua própria segurança. Acusados de crimes condenados pelo PCC, como estupro ou assassinato não "justificado", ou travestis, ou presos pertencentes a outra facção criminosa, eles, sob risco de morte, têm de permanecer resguardados do contato com todos os outros detentos, em uma enfermaria à parte ou em celas protegidas por um portão que, quando as trancas se abrem, tem que se fechar a chave. Nas Unidades Prisionais do Estado de São Paulo há várias facções criminosas, sendo a maior o PCC. Em cada unidade costuma atuar uma facção, e quem já esteve detido na de uma não pode ficar na de outra (SAFFI, 2009, p. 79). Atualmente há cinco ou seis facções criminosas, mas o PCC (também chamado de "Partido") domina mais de $80 \%$ das pessoas envolvidas com crime. A segunda maior facção é o CRBC ou "Romão", cujos membros são denominados por quem predomina de "coisas" ou "vermes". Como o CHSP é um hospital, acontece com frequência a permanência de membros de facções que não o PCC. Para eles, o seguro, conforme preconiza a

\footnotetext{
${ }^{9}$ Agradeço imensamente a Marcia Rodrigues Setubal por partilhar seu valioso conhecimento acerca do mundo prisional e oferecer essas informações.
} 
segurança da Secretaria de Administração Penitenciária do Estado de são Paulo, a SAP.

Para que seja feita a avaliação médica diária o ASP que acompanha a visita abre cela por cela solicitando, caso necessário, que o paciente vista a camiseta. Às vezes os próprios detentos se encarregam disso, gritando de outra cela através da pequena abertura retangular em cada porta: "olha o respeito com a doutora!". Assim, acompanhada por um ASP e a enfermagem de plantão passo, nos dias em que isso me cabe, de leito em leito, ou melhor, de cela em cela, para avaliar os pacientes internados pela psiquiatria. O quarto de enfermaria, maior, abriga uns dez pacientes, que geralmente necessitam de maior atenção da enfermagem pelo seu quadro, por exemplo paraplegia. Não há enfermaria dentro da ala psiquiátrica.

As enfermarias permanecem sempre abertas. As celas têm hora para serem trancadas e destrancadas. Na porta de cada uma delas, um número pintado, que não varia conforme quem lá esteja, e um papel com a identificação de seu ocupante temporário - nome e número de matrícula, que é o registro do detento na SAP. (Além desse número, há também o número de execução do Poder Judiciário e o número de registro do prontuário para identificar cada preso). Abaixo dele, uma abertura retangular de uns vinte por dez centímetros, através da qual sempre se pode ver o que quem está lá dentro faz. Alguns internos improvisam para essas aberturas cortinas de plástico, tecido ou papel, mas que sempre devem poder ser abertas pelo lado de fora - e que nem são teoricamente permitidas. É num pequeno parapeito nessas aberturas que as refeições são colocadas.

Cada cela, trancada com um imenso cadeado, tem uma cama hospitalar ou de alvenaria, dependendo da ala. Os pacientes com dificuldade de locomoção, da fisiatria ou da semi, precisam da cama hospitalar com proteção lateral, que serve também de apoio para auxiliá-los a se levantar; os da psiquiatria a necessitam para que possam ser nele contidos com faixas em caso de agitação psicomotora. A maioria das camas hospitalares, que são de metal, senão todas, estão tortas e desfiguradas. Não é raro o paciente da psiquiatria preferir colocar o fino colchão de espuma no chão. Não é raro tampouco os colchões serem rasgados por pacientes em crise de agitação, que os despedaçam e jogam os pedaços que agora cabem através 
da abertura da porta. Além do leito, uma mureta baixa apenas o suficiente para esconder o vaso sanitário, uma janela alta o suficiente para que através dela nada se possa ver, e uma pia. Já não há cheiro de hospital mas de "arapiraca", o fumo de corda que os detentos costumam fumar, misturado com odor de urina, de suor e com outro cheiro, indescritível, que talvez seja simplesmente a mistura de todos ou o cheiro do confinamento.

Nas paredes fotos cortadas de revista, alguns escritos ou desenhos, caixinhas de suco cortadas improvisando porta-coisas; fotos dos filhos, da mulher, da família; páginas inteiras de revista escolhidas de modo aparentemente aleatório, ou arrancadas de livros ou panfletos religiosos. Há celas todas decoradas, com desenhos a caneta de mulheres, armas ou símbolos, há outras cuidadosamente arrumadas, xampu, sabonete e pasta alinhados. A quantidade e variedade desses pertences e de cigarro indica se o ocupante da cela tem poder dentro da hierarquia velada que se edifica dentro da prisão. Segundo Souza, em Barbato Júnior,

O forte da cadeia não é o homem mais desenvolvido fisicamente. É o homem que tem visitas (importante relembrar: apenas 30\% dos que estão aqui recebem visitas). Através das visitas ele recebe cigarros (e dispõe da moeda padrão), frutas, bolachas, coisas diferentes. E pode ter influência, conforme o tipo de pessoa com quem se relaciona fora daqui ou com seu prestígio junto à administração. (...) Quando nada se tem a oferecer, então sim é que prevalece a lei do mais forte. (2007, p. 55)

No CHSP, e imagino que em qualquer prisão, há, porém, quem não queira receber visita para não ser visto pelos familiares em situação tão precária. Caso do Sr. Agemiro, caminhoneiro que pouco tempo após ser preso sofreu um acidente vascular cerebral que o privou de andar e dificultou muito sua fala e deglutição. Emagrecido, restrito àquele leito naquele lugar já tão restrito, ele preferia que a esposa não viesse para que não tivesse o desgosto de vê-lo assim. Se, segundo Goffman, "os presos (...) não podem impedir que os visitantes os vejam em circunstâncias humilhantes" (2013, p. 32), melhor, para alguns, que não haja visitantes.

Os desenhos que decoram as paredes foram muitas vezes feitos por ocupantes anteriores. Se no momento em que foram realizados tinham a função de 
tornar a cela um lugar mais próprio, sua permanência para os próximos internos, para quem aquelas figuras ou escritos não têm nenhum significado, faz justamente o oposto: atesta que o espaço entre cada uma daquelas quatro paredes não é um espaço de pertencimento. Outras histórias, outras noites insones, outras duras solidões.

Maneiras padronizadas de se comportar; celas iguais ou com diferenças impessoais, deixadas por ocupantes anteriores; roupas puídas que podem vestir qualquer um dos internos que tenham tamanho aproximado; permissão de apenas alguns poucos pertences: a pessoa que entra precisa obrigatoriamente aparar as peculiaridades que a identificam como si mesma para uma longa estadia. Quanto mais longa, mais faz falta justamente aquilo de que se privou. Nas palavras de Goffman acerca das instituições totais,

\footnotetext{
Uma vez que o internado seja despojado de seus bens, o estabelecimento precisa providenciar pelo menos algumas substituições, mas estas se apresentam sob forma padronizada, uniformes no caráter e uniformemente distribuídas. Tais bens substitutos são claramente marcados como pertencentes à instituição e, em alguns casos, são recolhidos em intervalos regulares para, por assim dizer, serem desinfetados de identificações. (...) 0 fato de não dar chaves aos internados e as buscas e os confiscos periódicos de propriedade pessoal acumulada reforçam a ausência de bens. (2013, p. 28)
}

Recordo-me de um episódio ocorrido logo após um atendimento a um paciente do seguro da ala B. Quando trancava o portão que separa aquela parte do resto da ala, eu já do lado de fora, o ASP que me acompanhava reparou que Kaio, saído de sua cela onde havíamos acabado de conversar, havia "estilizado" sua roupa: ele vestia, por cima da camiseta branca, o moletom bege do CHSP, mas rasgado na frente e sem as mangas como se fosse um colete, e um brinco feito de um pedaço de clipe ou arame enferrujado enfiado no furo da orelha. Prontamente e de forma constrangedora e hostil, o ASP exigiu a entrega do colete e do brinco, inconformado; resmungando impropérios, atirou-os no lixo - na prisão, o destino de tudo o que se aproxima de ser mais pessoal.

Na maior parte do sistema prisional o gosto por alimentos específicos pode em parte ser mantido, se o interno tem visita que possa levar o que sabe ser de sua 
preferência e que possa ser inspecionado na entrada. Um gesto carinhoso que não satisfaz só a vontade, mas diz que o interno é lembrado lá fora, cuidado, e que seus gostos - os seus! - continuam respeitados. Como o Centro Hospitalar do Sistema Penitenciário, é um hospital além de ser também uma prisão, não se permite a entrada de alimentos diferentes dos fornecidos e há, sobreposta à da prisão, a rotina do hospital. Às vezes, porém, pela distância ou por não terem sido incluídos no rol de visitas do CHSP, familiares ficam toda a estadia sem comparecer às quartas-feiras e domingos, dias de visita em todo o sistema penitenciário. Isso faz com que alguns dos pacientes queiram logo sua alta. A impossibilidade de cuidar dos já escassos pertences que ficam na unidade de origem se configura como outro motivo de pressa para ir embora. É comum, na volta para a "origem" (nome simplificado da unidade prisional de procedência), que os internos encontrem seus artigos de higiene, os poucos objetos pessoais e até o colchão já sob posse de outros detentos. Estes são motivos pelos quais alguns pacientes querem e solicitam constantemente por alta do CHSP, como se a alta dependesse exclusivamente da vontade do médico e não da condição de saúde de quem está doente. Por outros motivos, outros tantos preferem ficar - a superlotação das unidades prisionais de origem é um desses, perseguição por pessoas ou grupos específicos é outro. Atendi a um paciente que descobri, através de uma conversa com sua esposa, estar simulando apresentar um quadro psicótico aparentemente para retardar sua alta (ele havia sido internado pela clínica médica e o motivo da internação já havia sido estabilizado). Quando lhe perguntei se haveria algum motivo para não querer voltar para a origem ele me contou que, durante um dia de visita, desentendeu-se com alguém que depois descobriu ser do PCC e temia por sua vida quando voltasse para lá. Essa é uma história que no CHSP se repete cotidianamente. Houve quem aprendesse a simular alucinações e delírios porque lhe haviam dito que o CHSP era melhor que a origem e, no segundo dia de internação - talvez porque descobriu que estar ali não era, afinal de contas, nenhum paraíso - desmentisse tudo para receber alta. Assim como há quem esconda sofrimentos para não "sujar a pasta", o medo de que conste nos arquivos processuais algum diagnóstico psiquiátrico que atrapalhe no julgamento, embora eu equivocadamente já tenha insistido em dizer que nenhum juiz terá 
acesso ao seu prontuário médico e que aquele atendimento é para a sua saúde e não tem nada a ver com a lei ${ }^{10}$. Não creio ser à toa que ainda hoje o CHSP é conhecido entre os presos pelo seu nome anterior, COC ou Centro de Observação Criminológica, extinto em 2002, até quando aquele lugar servia para avaliações periciais, importando então a Justiça e não os internos, com quem deve se importar o CHSP. Coisa em que até hoje os pacientes detentos custam a acreditar.

Há alguns pacientes que agradecem o fato de estarem presos porque, se não estivessem, dificilmente estariam recebendo tratamento adequado de seu problema de saúde. Muitos internos com quadros plégicos sabem que não teriam acesso fácil a acompanhamento especializado de terapia ocupacional e fisioterapia para reabilitação, por exemplo. Ainda bem que estou aqui, dizem.

No primeiro ano de meu trabalho no CHSP atendia somente aos homens e, apenas eventualmente, quando havia alguma urgência, às mulheres. Com o aumento de minha carga horária passei a ser responsável também pela interconsulta das alas C e D, femininas. Eu não suspeitava, no entanto, que aquela aparentemente simples diferença de gênero implicava em outras diferenças muito mais significativas e desafiadoras.

Entrar na ala C, de mulheres internadas para tratamento clínico ou cirúrgico, significa estar exposta a muitos pares de olhos que me miram sem disfarçar, muito diferente de entrar nas alas masculinas. Além disso, como não há uma gaiola para as mulheres aguardarem atendimento ambulatorial, ficam na ala, no banco de concreto ou sentadas e deitadas no chão, todas as mulheres que esperam sua vez. Elas não estão internadas no CHSP e talvez por isso tenham ainda menos pudor de olhar: miram com um estranhamento impregnado ao mesmo tempo de curiosidade e desafio. Olham para as roupas que visto por debaixo do avental, olham os pés que entram e saem diariamente daquele lugar, olham para minha profissão, escolhida, diferentemente da de quase todas ali.

\footnotetext{
${ }^{10}$ Foi durante a revisão desta pesquisa que descobri que o juiz pode, sim, ter acesso aos prontuários dos pacientes, embora nenhuma informação contida neles possa ser usada contra a pessoa em julgamento, mas somente a seu favor. Agradeço tal "descoberta" a Marcia Rodrigues Setubal e Tatiana Ramos Malavasi Sales.
} 
0 tratamento que se dispensam as internas é muito diferente daquele vivido entre os homens. Havia, certa vez, uma estrangeira internada. Ela fumava muitos cigarros por dia antes de ser presa e estava sofrendo terrivelmente com a falta de cigarros, já que não tinha visita que os trouxesse. Implorava às ASPs que the arranjassem um, fumava "bitucas" deitadas fora, humilhava-se diante das colegas de ala para que lhe dessem de fumar. Na mesma época atendi a um estrangeiro internado na ala B. Perguntei-lhe se fumava. Sim, ele disse calmamente. E como consegue cigarros? Eles me dão!, ele falou, quase estranhando a minha pergunta, referindo-se aos companheiros de ala. Sem que tivesse nem que pedir.

A ala $\mathrm{D}$, por sua vez, é um mundo à parte dentro daquele mundo já à parte. Lá é onde ficam as mulheres no chamado trânsito amamentação: o período entre o parto e a entrega do bebê, de aproximadamente seis meses, tempo recomendado para que haja amamentação exclusiva. Seis meses seria o tempo mínimo do trânsito amamentação, mas ele foi transformado pela SAP em tempo máximo.

As internas da ala D não estão formalmente internadas e não necessitam ser vistas diariamente por um médico, como acontece em todo o CHSP (e em todos os hospitais). Elas ficam lá por um período longo, num espaço que se tornou delas. Não há nem sala de enfermagem na ala D (em todas as outras, há). A que havia, foi inativada. As celas tampouco são trancadas em horários determinados como em todo o resto do hospital. Em cada uma, a mãe com seu bebê, roupinhas, enfeites improvisados com papel de marmitex, leite em pó, fraldas. Todas deveriam ter um bercinho onde o bebê dormisse, mas a escassez de berços e a hierarquia que existe entre as internas fazem com que algumas tenham e outras não. Nessa ordem, não há como interferir. É uma ordem que acaba prevalecendo sobre qualquer outra, mesmo a de segurança ou a médica.

Eu costumava chamar todos os pacientes para atendimento no corredor psicossocial, mas quando a demanda é muito grande e muitos pacientes precisam de acompanhamento a solução é ir conversar com eles na ala mesmo, pois só a locomoção de cada um até o corredor tomaria muito tempo. Comecei então a entrar na ala D para falar com as seis ou sete mulheres que precisam de atendimento psiquiátrico. A ala D, porém, é tão pertencente às mulheres que lá estão que uma 
ASP veio me perguntar, desconfiadíssima, qual era meu interesse em entrar na ala, suspeitando que eu fosse levar para dentro algo que não poderia. Para que mais, ora, uma médica iria querer entrar ali?

Logo ao adentrar o portão, se faço menção de me embrenhar pelos corredores debaixo ou de cima, escuto, bem alto, numa tonalidade tão específica, uma mulher avisando às outras que estão lá dentro que há gente de fora entrando. OLHA A MÉDICA ENTRAAAAAAAAAANDO000000! Quase um canto. Um aviso cheio de sentidos. Escondam o que não pode ser visto; arrumem-se e aos seus filhos; tem gente estranha entre nós.

No pátio, em dias de sol, varais se estendem cheios de roupinhas a secar. As paredes são diferentes, esverdeadas e com alguns desenhos. No chão, marcas desbotadas do que seria uma quadra de esportes. Mal reconhecíveis Mickeys, Minnies, Magalis e Cebolinhas, grotescamente desenhados nas paredes, tentam enfeitar aquele ambiente cheio de crianças e muito mais movimentado que qualquer outra parte do CHSP, mas em que estar detrás das grades parece pesar mais que em qualquer outro lugar. Pelo fato de que, por meses, aquele espaço restrito será tudo o que aquelas crianças conhecerão do mundo; e pelo fato de que, findos esses meses, elas deverão deixar para trás a maior parte de seu mundo infantil: suas mães.

Na ala D a moeda de troca não é só o cigarro. Pode-se lavar roupa de bebê, há leite, há móbiles para se fazer em papel de marmitex. Brinquedos mesmo, quase não há. As crianças têm dificuldade em desenvolver a preensão palmar porque não têm o que apreender com a mão; quando, enfim, têm acesso a brinquedos, não os reconhecem, embora reconheçam o saquinho de fralda ou o saquinho de pão. ${ }^{11}$ Durante o atendimento de sua mãe uma bebê olhava encantada para meus brincos coloridos, um encanto mais surpreso que aquele com o qual os bebês admiram os penduricalhos dos adultos. Não há brincos nem tantas cores, exceto em dia de visita: neste dia a maquiagem é tanta que cheguei a suspeitar (eu, psiquiatra) que algumas mulheres, com sombra tão carregada nos olhos, batom, lápis, parecendo prestes a desfilar num bloco de carnaval - o rosto, porque no corpo sempre a mesma roupa

\footnotetext{
11 Devo essa observação à terapeuta ocupacional Priscilla Spinola, que desenvolve um belíssimo trabalho com as mães da ala D e seus bebês, aproximando-os e estimulando seu desenvolvimento.
} 
bege - estivessem apresentando um quadro de mania psicótica. Agora, já aprendi que o excesso de maquiagem é a tentativa explícita de condensar, nos poucos momentos diante da visita, tudo o que não pode ser vivido junto, toda a saudade que se sentiu e que se seguirá sentindo.

Alguns dias, na ala D, entram pessoas ligadas a alguma igreja, todas de preto, carregando crucifixos e bíblias. Acumulam-se em volta da mesa, rodeadas das mães que desejam rezar, e oram, mãos levantadas não para o céu, mas para o andar de cima e para o arame que cobre o pátio. Na prisão, só há dois assuntos possíveis, disseram-me algumas vezes: o crime ou a bíblia.

Além da hierarquia, na qual a equipe de segurança assume um grande topo e os internos uma base maior ainda - pois "qualquer pessoa da classe dirigente tem alguns direitos para impor disciplina a qualquer pessoa da classe de internados(...)" (GOFFMAN, 2013, p. 45), as gírias e os códigos da malandragem levantam outra barreira que não os muros para separar os de dentro dos de fora. É como se, através da linguagem cifrada que se tem que aprender quando se entra na cadeia, os detentos reclamassem para si a diferenciação de si mesmos contra a mera condição de estar presos - nós é que nos diferenciamos, eles diriam ao se mover dentro do código do crime. Segundo Jocenir, em Barbato Júnior,

Na prisão há um outro universo, regido por regras próprias, e um código de honra muito forte, sua violação representa a pena de morte". (...) Todo o mecanismo ao qual estão subordinados é engendrado pelos próprios presidiários, ainda que, em alguns momentos, possa haver tensão entre sua sistemática e as orientações prisionais formais. (2007, p. 51)

0 código do crime se alastra também para as ruas, criando através de quem é solto ou de quem ainda não foi preso um prolongamento desse mundo a que foram confinados, mas que tomaram para si. Quem chega traz notícias, quem sai, as leva:

Além das notícias dadas sobre parentes, amigos e namoradas, há, evidentemente, a narrativa sobre a atual situação de seus comparsas no mundo do crime. Com frequência, os detentos de um presídio obtêm informações precisas sobre o julgamento e a consequente condenação de um companheiro. A rede de notícias é (...) vivaz (op. cit. p. 69) 
Na prisão, a notícia que conta é a do crime. É como se as grades, retirando cada um que é detido do mundo comum, fosse "permeável" somente ao mundo do crime - comunicação majoritária ali. Ouso dizer que alguém que queira notícia de fora - é melhor, porque mais fácil, que seja notícia do mundo do crime. 0 crime vira a ligação entre o dentro e o fora. "A comunicação dos detentos com criminosos livres é uma prática recorrente nos presídios brasileiros. Como é sabido, é fácil a aquisição de celulares" (op. cit. p. 70), entre outras possibilidades.

Tal rede de notícias dentro do hospital torna-se ainda mais complexa e vivaz, já que ali os internos costumam permanecer temporariamente, com oportuno contato com detentos de diversas outras unidades prisionais, retornando em seguida atualizados para suas unidades de origem.

A ligação com o mundo "comum" se dá através das visitas, aos domingos e quartas-feiras, de cartas, sempre abertas e lidas pela segurança antes de serem entregues (embora esta prática seja inconsitucional: segundo a lei, a correspondência é inviolável), através de aparelhos individuais de rádio e através de alguns aparelhos de televisão. Estes ficam dentro das enfermarias nas alas A e B, próximo da enfermagem na ala psiquiátrica, no meio do corredor nas alas $\mathrm{C}$ e $\mathrm{D}$ e diante das gaiolas no corredor dos ambulatórios. Não há televisão no seguro. A televisão da enfermaria de psiquiatria foi doada pela avó de uma psiquiatra e, para que os pacientes a assistam, precisam sentar numa das três cadeiras fixadas ao chão, coladas às grades que circundam o posto.

Dentro das alas as funções como separar as roupas para a lavanderia e chamar os pacientes que serão atendidos em outro local (com uma daquelas das três vias da lista dos pacientes que fazemos a cada manhã) são divididas entre os internos. Há o "piloto" e o "disciplina" da ala, obrigatoriamente pertencentes ao PCC, para quem todos os outros devem satisfação - o piloto, hierarquicamente superior, pode ter influência em toda a unidade prisional, enquanto o disciplina é "responsável" somente por sua ala. 
É comum que os internos se ajudem, e muitas valiosas informações de anamnese são obtidas através do paciente que está ao lado na enfermaria: ele não está comendo, doutora, ou não está falando coisa com coisa desde não sei quantos dias. Barbato Júnior nos diz que

A solidariedade é outro sentimento que habita o mundo do cárcere. Entre os detentos, o companheirismo parece ser intrínseco às suas vidas. Mesmo que tenham discordâncias, por conta de ressentimentos pessoais, elas parecem se exaurir quando do irrompimento de alguma dificuldade. (op. cit., p. 76).

Solidariedade ou simplesmente confraternização, como o denomina Goffman, descrevendo algo que se assemelha à surpresa que eu mesma tive ao me deparar, no início de meu trabalho no CHSP, com pessoas comuns que tiveram o infortúnio de serem presas:

Mais importante, como uma influência reorganizadora, é o processo de confraternização, através do qual pessoas socialmente distantes desenvolvem apoio mútuo e resistência a um sistema que as forçou à intimidade numa única comunidade igualitária de destino. 0 recém-admitido frequentemente parte de algo semelhante às concepções erradas e populares da equipe dirigente quanto ao caráter dos internados; acaba por descobrir que quase todos os seus companheiros têm todas as qualidades de seres humanos comuns, ocasionalmente decentes, e que merecem simpatia e apoio. (2013, p. 55)

Como contraponto Barbato Júnior coloca, através de depoimentos de Percival de Souza, que "A solidariedade aqui é algo difícil de se encontrar. Há muita inveja. Raiva de quem recebe visitas (...), ódio de ver o outro sair em liberdade.", e de Horácio Indarte: "Se tem a impressão de que as pessoas do lugar são até solidárias, mas tudo é com segundas intenções. Jamais me iludi" (2007, p. 76), ambos detentos em algum período de suas vidas. Goffman também contrapõe e limita o alcance da confraternização, restringindo-a a mera resposta à coerção, sem que resulte sempre na possibilidade de fortalecimento de grupo:

Embora haja tendências de solidariedade - por exemplo, confraternização e formação de "panelinhas" - tais tendências são limitadas. As coerções que colocam os internados numa posição em que podem identificar-se e comunicar-se não levam necessariamente a elevado moral de grupo e à solidariedade. (2013, p. 58) 
Diz-se de uma apreensão constante, que poderia ser descrita como Boétie o faz acerca de quem se aproxima do tirano - sem nos esquecermos de que, em se tratando da prisão, tal "tirano", se existe, pode estar oculto ou dentro de cada um:

Que sofrimento, que martírio, Deus do céu! seguir noite e dia pensando em aprazer a um e no entanto temê-lo mais que a homem do mundo, ter olho sempre à espreita, a orelha à escuta para espiar de onde virá o golpe, para descobrir as emboscadas, para sentir a fisionomia de seus companheiros (...). (1982, p.37)

Creio que ambos, a solidariedade e o oportunismo coberto dum egoísmo raivoso, estão presentes na prisão. A própria frustração diante da ocasional ou constante ausência de solidariedade fala da expectativa de sua existência, que acaba subsidiando retaliações mesmo que a expectativa seja, desde sempre, dificilmente cumprida: “(...) embora usualmente exista pouca lealdade de grupo nas instituições totais, a expectativa de formação dessa lealdade constitui parte da cultura do internado e está subjacente à hostilidade com relação aos que rompem a solidariedade dos internados." (GOFFMAN, 2013, p. 59) É um mundo complexo, que foge a simplificações, caricaturas e maniqueísmos, assim como quem nele está. Talvez a solidariedade que há no cárcere, mesmo ladeada de seu inverso, seja uma das poucas maneiras que existe ali de se manter na dignidade do homem. Moura nos diz que

Os humanos confirmam sua humanidade quando incluídos em comunidades onde há troca de dons. Humilhação, nessa perspectiva, designa o estado de quem perdeu a percepção social de si próprio como de um doador. Humilhado sendo quem tenha sido publicamente congelado na figura do carente, alguém de quem cabe nos ocuparmos e que estaria impedido, ele próprio, de ocupar-se de alguém. (2007, p. 27).

Participar da rotina e da divisão de tarefas, ajudar um cadeirante a se sentar, fornecer informações que possam servir para a melhoria da saúde de quem está ao lado seriam então formas de se ocupar de alguém, retirando-se assim da possibilidade de congelamento na figura do carente. Adentrar uma ordem menos petrificada que as regras impostas pela instituição prisão, submetendo-se ao piloto e ao disciplina da ala, aprendendo códigos mais espontâneos e mutáveis (além de, e 
ainda que necessários), talvez sejam remissões, mesmo que longínquas, à possibilidade de um coletivo.

Antes das $10 \mathrm{~h}$ os corredores ficam vazios e a comunicação entre os detentos se dá com assovios, gritos, ou barbantes atirados com um peso de uma a outra abertura da cela. Um ou outro tem o "privilégio" de sair da tranca para a inalação. Depois que a tranca é aberta, outro panorama se dá: rodinhas de conversa, descanso ao sol, detentos tentando se exercitar no pequeno espaço do pátio. Os pacientes da psiquiatria podem ou não ser liberados para descer ao sol (os leitos de internação psiquiátrica ficam no piso superior da ala $A$, na área equivalente aos leitos do seguro da ala B), se não estiverem agitados ou desorganizados, ou se forem avaliados como apresentando risco baixo de "arranjar confusão" ou de usar maconha ou cocaína. Crack nunca há, pois o PCC recrimina. É recomendado que a visita médica aconteça antes das dez horas da manhã, quando a tranca ainda está fechada.

Antes das dez da manhã predomina o silêncio, cortado por um grito aqui ou ali ou pelas batidas na porta de algum paciente exigindo um "bic" para acender seu arapiraca. Os cigarros, escassos, são valiosos e fumados sempre até o final, deixando nos dedos de quase todos marcas marrons de repetidas queimaduras. Dói mais a falta do cigarro que a brasa queimando o dedo. Quanto aos sons William da Silva Lima explica que

Para os que vivem em liberdade, a visão é o sentido mais importante. Para nós, é a audição: o molho de chaves que tilinta, a porta que range, o assovio do amigo, o pigarro combinado, vozes ao longe, passos num corredor - ao percebê-los e interpretá-los rapidamente, ainda pode haver tempo para tomar providências. Quando o alarme vem dos olhos é sinal de que a coisa está feia: o preso só vê quando foi visto primeiro. (in BARBATO JUNIOR, 2007, p.76)

Falando durante um atendimento sobre algumas dificuldades do dia a dia do encarceramento um paciente, alocado numa das enfermarias com alguns outros colegas, queixava-se de não conseguir escrever. Perguntei-lhe se a dificuldade se devia à falta de privacidade, e ele respondeu que não. Já estivera também em cela individual, e tampouco ali podia escrever. O silêncio era demais insuportável. Tudo 
quieto. Quando passava lá fora algum carro com som alto, lembrava-se de casa. Lá, os barulhos eram familiares. Na prisão, não. Sobre o motivo que o impedia de escrever, ele continua: "aqui não tem o momento de escrever, é uma tensão constante. Não dá para parar, pensar, refletir, achar palavra difícil." Gonçalves Filho parece descrever aquele momento que falta à prisão quando fala da possibilidade de relaxar:

Relaxar significa a capacidade de carregar e aproveitar a solidão: é devaneio sem pressa de integração ao ambiente. A cena está então preparada para uma aparição pessoal. Surge uma sensação, um impulso vago, mais ou menos angustiante. Aos poucos, o impulso é assumido. Direções começam a esboçar-se. A vida adquire forma e sentido, ações e obras vão desabrochar. 0 impulso não foi desperdiçado e frutificou. Somente sob essa circunstância (...) (alguém) pode ter uma experiência que é sentida como real. (...) Quem esteja impedido de relaxar tende a especializarse em comportamentos submissos ou estereotipados e que vai esforçar-se por tomar como satisfatórios. (...) E há a alternativa dos comportamentos anti-sociais que, no rastro ainda de Winnicott, devemos interpretar menos como um ataque dirigido aos outros do que como uma demanda de receptividade. (2007, pp. 190191)

Na prisão, não existe a possibilidade de relaxar, nem quando se dorme. Como descreve Goffman, "geralmente há necessidade de esforço persistente e consciente para não enfrentar problemas." (2013, p. 45) Os impulsos não frutificam, menos em violência, que poderia ser o avesso do fruto; dificilmente ações e obras desabrocham e muitas vezes a única sensação de realidade vem do medo.

Parece ser muito mais difícil alcançar a remissão do quadro psicótico de um paciente na ala psiquiátrica do CHSP que em outras enfermarias psiquiátricas de hospitais comuns, talvez porque ajam em direções opostas os neurolépticos e as substâncias psicoativas ilícitas (que entram, você sabe, né doutora, já escutei de alguns pacientes; de tantos outros, escuto com mais frequência que ali não tem nenhuma droga, o que me dá indícios de que quase tudo que me é dito é selecionado de acordo com um código prévio - e que dificulta, se não impede, a possibilidade de formação de um vínculo terapêutico de confiança), talvez porque a prisão seja, em si, de alguma forma psicotizante. Daí ser tão difícil, por exemplo, avaliar se um paciente do seguro que diz estar sendo perseguido vive ou não um surto psicótico. Ou lidar com um paciente que teme um guarda ali fora à espreita, enquanto vemos, 
eu e ele, através da janela da cela, o vigia em ronda na torre de segurança (a única coisa que se consegue ver através de algumas janelas, além de pedaços de céu).

Difícil também o aprendizado da diferenciação de sintomas "verdadeiros" e de outros, simulados com o intuito de obter um período de internação ali, que oferece condições que costumam ser melhores que as proporcionadas pelas Unidades Prisionais de origem dos detentos, já que segundo dados de junho de 2012, a população carcerária, de 190.818 indivíduos, conta com 102.183 vagas (dados do Sistema Integrado de Informações Penitenciárias, InfoPen). Muitos prefeririam ficar internados, e não são raras as histórias de amostras de urina "emprestadas" de outro paciente, ou de tentativas muitas vezes bem sucedidas de aumentar feridas operatórias ou impedir sua cicatrização com as próprias mãos, a fim de retardar a alta do hospital.

A irrupção de crises de agitação psicomotora entre os pacientes psiquiátricos do CHSP às vezes se dá de forma tão violenta e refratária aos psicotrópicos utilizados que já presenciei situações como a inundação do chão porque um paciente quebrara o registro de água e, por conta de sua extrema agitação, ninguém conseguia se acercar sob risco evidente de ser agredido, enquanto o nível de água do chão ia subindo mais e mais; e em outra ocasião pancadas tão fortes na porta da cela que causaram sua queda (o que foi de fato impressionante, pois a porta é de ferro, soldada, trancada com um cadeado grossíssimo). Uma cena insólita, chegar à ala psiquiátrica e, entre as celas trancadas, uma completamente aberta, vazia, sem porta: a porta encontrava-se no chão, de ferro, inútil. Completando o absurdo da cena, o paciente que, por ser mais calmo, fora alocado temporariamente para a cela agora sem porta, "lavava" o piso que supunha contaminado pelo paciente anterior com água do vaso sanitário. A pia, muito mais frágil que a porta de ferro, logicamente já havia sido quebrada muito antes da porta.

Outras peculiaridades do hospital prisional permeiam os atendimentos e seus arredores: muitos pacientes, por exemplo, não comparecem ao corredor psicossocial quando chamados para atendimento porque estão com a barba mal feita e são, por isso, impedidos pelos ASPs de sairem da ala. A alta, diferente do que ocorre nos hospitais comuns, não deve ser anunciada, já que há risco de organização 
de fuga, apesar de o trânsito dos pacientes sempre se dar com escolta policial. E quando ela acontece muitas vezes o paciente fica dias a mais internado, esperando o bonde de sua penitenciária de origem, às vezes de alguma cidade horas distante dali, estar disponível para vir buscá-lo.

As diferentes equipes de saúde mostram diferentes modos de abordagem do fato de os pacientes encontrarem-se não apenas enfermos, mas também presos. A maioria dos médicos não pergunta propositalmente nada acerca do crime ou pena para que isso não influencie na qualidade de seu atendimento. A equipe de saúde mental precisa perguntar por serem informações muito importantes para a nossa avaliação. 0 meu jeito de perguntar, no entanto, mudou com o tempo: antes eu questionava a cada um a quanto tempo havia sido condenado, até que alguém me respondeu: condenado, não, doutora, quem condena é Deus. Minha sentença é de tal tamanho.

Lembro-me de uma cirurgiã haver saído muito abalada do centro cirúrgico por ter reconhecido no paciente que estava prestes a operar o homem que a havia mantido sequestrada por algumas horas, meses antes. Mundos, dentro e fora, que ali se encontram.

Mundos que se encontram ali, dentro daquele mundo, são também as em si já complexas instituições hospital e prisão, cujo encontro parece multiplicar a complexidade de ambas. Rotinas e pressupostos distintos fazem com que o contato entre as equipes de cada uma tenham pontos algumas vezes conflituosos no dia a dia. Assim, médicos, psicólogos e terapeutas ocupacionais que cheguem às $7 \mathrm{~h}$ precisam esperar até às $8 \mathrm{~h}$, horário estipulado pela segurança, para iniciar os atendimentos dentro das alas e necessitam ser acompanhados por um ASP. Há manhãs em que por ocasião da realização de blitz não se pode entrar nas alas e assim não se pode nem ao menos fazer a avaliação diária de pacientes internados enquanto o procedimento de segurança está acontecendo. Houve momentos dramáticos ocorridos devido ao fato de ali ser simultaneamente um hospital e uma prisão, por exemplo, encontrar-me diante de um paciente agitado, trancado em sua cela, e ter que aguardar intermináveis minutos até que alguém da segurança estivesse disponível para abrir a tranca. 
Se há complexidades que se dão no encontro entre a prisão e o hospital, há outras que se estabelecem já no âmbito da segurança. Já de início, a visão que a equipe de segurança e os internos têm de si é mutuamente estereotipada, o que muito raramente deixará de ser. Quanto a isso, nos descreve Goffman que

Cada agrupamento tende a conceber o outro através de estereótipos limitados e hostis - a equipe dirigente muitas vezes vê os internados como amargos, reservados e não merecedores de confiança; os internados muitas vezes vêem os dirigentes como condescendentes, arbitrários e mesquinhos. Os participantes da equipe dirigente tendem a sentir-se superiores e corretos; os internados tendem, pelo menos sob alguns aspectos, a sentir-se inferiores, fracos, censuráveis e culpados. (2013, p. 19)

A maneira como se veem e se tratam os internos e a equipe de segurança responde a estereótipos, mas não apenas a isso: responde também à complexidade da relação entre pessoas sujeitas e/ou tendo que sujeitar outros a diferentes regras, pessoas que se encontram num mesmo lugar ocupando, de cada lado, posições opostas. 0 tempo de convívio, que torna possível o surgimento de afeição de ambos os lados, também faz da relação entre os internos e a equipe de segurança (e também a equipe médica) muito difícil de simplificar. Os ASPs, por exemplo, têm tarefas que, em si, apresentam-se desconfortavelmente ambíguas. Segundo descreve Santos,

Na hierarquia penitenciária, a direção está no cume, os internos no ponto mais baixo. Comprimidos entre eles, encontram-se os agentes, que devem obediência ao diretor, e que também têm como responsabilidades o funcionamento da prisão. Aos agentes, compete concomitantemente tratar o interno como indivíduo único, mas contá-lo como objeto no momento dos "conferes"; respeitá-lo como um ser dotado de prerrogativas inalienáveis, dentre as quais ressaltam o direito à intimidade, porém revistar-lhe frequentemente o cubículo, remexendo-lhe os objetos pessoais e vistoriando as roupas que está vestindo, inspecionando-o até mesmo nas partes mais íntimas do corpo; captar-lhe a confiança e trancá-lo à chave numa cela. (2003, p. 27)

0 fato de ambas as equipes que têm contato direto com os internos, a de saúde e a de segurança, entrarem e saírem diariamente exerce um papel importante na vida de quem está confinado - assim como estar diante do confinamento o faz para quem entra e sai todos os dias. Tenho a impressão, às vezes, de que ao entrar 
levo comigo um pouco do fora - e falo apenas do que é permitido carregar para dentro: olhos que olharam um céu mais amplo, ouvidos que ouviram notícias vivas, vestes de cores diferentes, rosto impresso com os diversos que o dia me presenteou. 0 infinito das possibilidades de quem entra, mas sai, é maior que o infinito das possibilidades de quem deve permanecer, por mais ilógico que possa parecer o absurdo de infinitos terem tamanhos diferentes. Mas têm, e no entanto continuam infinitos. Por isso suspeito tanto da sensação que me invade ao deixar aquele lugar: a inevitável e equivocada sensação de que, da próxima vez que eu entrar ali, tudo estará do mesmo jeito.

Apesar de que ali se vive, apesar de que ali se morre. Apesar de que eu, a cada vez, mesmo sem perceber, saia de um jeito diferente do qual entrei. 
ATIVIDADE DO HOMEM, NO HOSPITAL PENITENCIÁRIO

Hannah Arendt, pensando acerca da vida do homem, admite a existência de dois modos nos quais ela acontece, a vita contemplativa e a vita activa. Em $A$ Condição Humana, ela se debruça sobre o segundo destes modos para se propor a "refletir sobre o que estamos fazendo" (2007, p. 13). Percebe então, nesta reflexão, que as atividades práticas dos homens não são todas da mesma ordem mas segundo suas peculiaridades, distinguem-se em três: o trabalho, a obra e a ação ${ }^{12}$. Não está no escopo desta investigação discorrer de maneira aprofundada sobre cada uma destas atividades, porém me pareceu importante pensar que lugar ocuparia a prisão no fazer humano como Arendt o coloca, ou como as atividades dos homens se realizam no contexto específico que é o aprisionamento, já que a liberdade, como se verá adiante, tem íntima correlação com uma delas, a ação.

O homem deve sua sobrevivência individual e a continuidade da espécie humana à primeira das três atividades, o trabalho. Etimologicamente, o termo e seus equivalentes antigos ou modernos "têm uma conotação inequívoca de experiências corporais, de fadigas e penas; e na maioria dos casos eles também são usados, de modo bastante significativo, para as dores do parto." (ARENDT, 2005, p. 179). É através do trabalho que o homem elimina constante e fugazmente suas necessidades como se alimentar e vestir, produzindo bens de consumo que, sendo consumidos, deixam inevitavelmente renovadas estas necessidades que, incessantes, voltam a surgir. Assim, cíclico, eternamente repetido, o labor estabelece o metabolismo do homem com a natureza e torna-o parte dela. A força de trabalho é igual para todos podendo variar, se o faz, somente em quantidade. Não é através dela portanto que o homem se exerce em sua individualidade, pelo contrário; o que trabalha no homem é o que nele há em comum com todos as espécies animais que vivem sobre a terra. Quem trabalha é o homem enquanto animal laborans.

0 produto do trabalho só pode ser consumido quase de imediato, pois não perdura. Como descreve Arendt,

12 Utilizarei os termos nos quais se distingue a vita activa segundo a tradução de Adriano Correia de "Trabalho, obra, ação", cuja opção seguiu as próprias indicações de Arendt. (2005, p. 196) 
Os bens de consumo, o resultado imediato do processo de trabalho, são as menos duráveis das coisas tangíveis. (...) Depois de uma breve permanência no mundo, retornam ao processo natural que os forneceu, seja através da absorção no processo vital do animal humano, seja por deterioração; (...) Eles são as menos mundanas e, ao mesmo tempo, as mais naturais e necessárias de todas as coisas. (...) Por conseguinte, não podem ser "acumulados" ou "armazenados". (2005, p. 181)

O suor, o esforço e a pena através dos quais os necessários bens de consumo são produzidos para se consumirem e não para perdurar, alternados com o também necessário descanso regenerador, mantêm o homem inserido no ritmo cíclico e infinito da natureza. Isto não significa, como pode parecer, que o trabalho tenha uma valoração menor, pejorativa, dentro das atividades humanas. 0 trabalho, justamente por suas características, permite ao homem uma experiência que lhe é essencial e que ultrapassa a sobrevivência também obtida através dele. Nas belas palavras de Arendt, "Uma vez que o trabalho corresponde à condição da própria vida, participa não apenas das suas fadigas e penas, mas também da mera felicidade com que podemos experimentar o fato de estarmos vivos." (op. cit., p. 182) ${ }^{13}$. Quanto ao caráter rotineiro do trabalho e sua importância, nos diz Arendt que

Um elemento de trabalho está presente em todas as atividades humanas, mesmo na mais elevada, na medida em que elas são executadas como tarefas "rotineiras" mediante as quais ganhamos a vida e nos mantemos vivos. Seu próprio caráter repetitivo, que na maioria das vezes sentimos ser um fardo que nos extenua, é que fornece aquele mínimo de contentamento animal para o qual os grandes e significativos momentos de alegria, que são raros e jamais duram, nunca podem ser um substituto e sem o qual os mais duradouros momentos de verdadeira aflição e tristeza, embora igualmente raros, dificilmente poderiam ser suportados. (op. cit., p. 183)

Diferentemente do trabalho, feito com o corpo e cujo fruto se consome de imediato, é através da obra que o homem pode, com suas mãos, fazer seu próprio

\footnotetext{
13 Para descrever o trabalho e sua graça enquanto atividade do animal humano e sua continuidade no tempo, acho profícua a música Amor de Índio, de Ronaldo Bastos e Beto Guedes: "Tudo que move é sagrado/E remove as montanhas/Com todo cuidado, meu amor/Enquanto a chama arder/Todo dia te ver passar/Tudo viver ao teu lado/Com o arco da promessa/No azul pintado pra durar/Abelha fazendo mel/Vale o tempo que não voou/A estrela caiu do céu/O pedido que se pensou/O destino que se cumpriu/De sentir teu calor/E ser todo/Todo dia é de viver/Para ser o que for/E ser tudo $(\ldots)$.
} 
mundo. É pela obra que surgem os objetos de uso, importantes pela própria utilidade mas, além disto, por serem as coisas que nos rodeiam e que tornam familiar e duradouro o mundo em que vivemos - ao mesmo tempo em que constituem esse próprio mundo. Nas palavras de Arendt, o homem enquanto homo faber "fabrica a mera variedade infinita das coisas cuja soma total constitui o artifício humano, o mundo em que vivemos." (loc. cit.)

É a existência de um mundo que já havia antes de sua chegada ao nascer e que perdurará após sua morte que o homem deve a confiabilidade e realidade necessárias para, de alguma forma, remediar a instabilidade constituinte do homem e dos homens, presente individualmente e quando os homens agem entre si. Interpondo-se entre os homens, o mundo simultaneamente os separa e os relaciona, intermediando a convivência dos que nele habitam em comum (ARENDT, 2007, p. $62)$.

A obra, através do processo de fabricação - necessariamente violento, pois não prescinde de certo grau de destruição da natureza para se dar -, proporciona ao homem segurança de si através da mesma violência, que é a "mais elementar sensação da força humana" (op. cit. p. 153).

Enquanto o trabalho é cíclico, prendendo-se ao processo vital do corpo e da natureza e não tem começo nem fim, a obra, enquanto fabricação, parte de um começo definido e chega a um fim também definido e previsível (op. cit. p. 156). 0 produto da obra é feito para durar, embora incidentalmente não dure ${ }^{14}$, e é reversível, pois as mãos humanas são capazes de destruir tudo o que elas mesmas produziram (diferentemente da ação, que além de irreversível tem consequências imprevisíveis, como veremos adiante). A distinção entre meios e fins atravessados ambos pela utilidade é característica da obra e não concerne ao trabalho, cíclico, interminável e com um caráter de automatismo por ser "um movimento

\footnotetext{
14 Quanto à diferença entre a durabilidade dos produtos do trabalho e da obra, nos esclarece Arendt: "Contudo, embora o uso não deixe de desgastar estes objetos, este fim não é previamente planejado, não era o objetivo de sua fabricação, como a "destruição" ou o consumo imediato do pão é o seu fim intrínseco; o que o uso desgasta é a durabilidade. Em outras palavras, a destruição, embora inevitável, é incidental para o uso, mas inerente ao consumo." (2005, p. 183)
} 
autopropelido e, portanto, fora do alcance da interferência voluntária ou intencional" (op. cit. p. 164).

A ação, por sua vez, concede ao homem a possibilidade de se fazer verdadeiramente homem. Ela, juntamente com o discurso, nos dá a possibilidade de uma vida humana além da biológica e além daquela condicionada pela categoria de meios e fins. Sua condição é a pluralidade humana,

\begin{abstract}
que tem o duplo aspecto de igualdade e diferença. Se não fossem iguais, os homens seriam incapazes de compreender-se entre si e aos seus ancestrais, ou de fazer planos para o futuro e prever as necessidades das gerações vindouras. Se não fossem diferentes, se cada ser humano não diferisse de todos os que existiram, existem ou virão a existir, os homens não precisariam do discurso ou da ação para se fazerem entender. (...) Só o homem (...) é capaz de comunicar a si próprio e não apenas comunicar alguma coisa - como sede, fome, afeto, hostilidade ou medo. No homem, a alteridade, que ele tem com tudo o que existe, e a distinção, que ele partilha com tudo o que vive, tornam-se singularidade, e a pluralidade humana é a paradoxal pluralidade de seres singulares. (op. cit. pp. 187-188)
\end{abstract}

Só a ação e o discurso dão ao homem a possibilidade de se inserir no mundo humano sob o que se configura então como a confirmação do nascimento biológico individual, através de como um segundo nascimento "no qual confirmamos e assumimos o fato original e singular do nosso aparecimento físico original" (op. cit. p. 188); a ação e o discurso dão ao homem a chance de se tornar quem ele singularmente é, pela possibilidade que inauguram do surgimento do novo que somente cada homem é capaz de iniciar como si mesmo. A ação e a fala são sempre pessoais e não tem sentido sem autoria, assim como, reciprocamente, se não agisse ou falasse o homem nunca poderia responder "à questão colocada a todo recémchegado: "Quem é você?"”' (ARENDT, 2005, p. 191).

A resposta para essa questão, o homem só pode dar através da expressão de sua singularidade: o início de algo novo. Nomeando essa possibilidade de milagre, diz-nos Arendt:

(...) o novo sempre surge sob o disfarce do milagre. 0 fato de que o homem é capaz de agir significa que se pode esperar dele o inesperado, que ele é capaz de realizar o infinitamente improvável. E isto, por sua vez, só é possível porque cada homem é singular, de sorte que, a cada nascimento, vem ao mundo algo singularmente novo. 
Desse alguém que é singular pode-se dizer, com certeza, que antes dele não havia ninguém." (2007, p.191)

Cada uma dessas atividades - o trabalho, a obra e a ação - se dá, pela sua natureza, na esfera pública ou na esfera privada.

Originalmente a esfera privada se caracteriza por ser onde o homem garante sua sobrevivência através do trabalho. É aí que está cada homem como membro de sua espécie, cuidando de suas necessidades vitais - alimentar-se, abrigar-se, reproduzir-se, manter-se saudável - e também o lugar onde se situa a família, cujas atividades seriam a reprodução do contínuo esforço individual de manter-se vivo através da incessante mitigação da necessidade sempre vigente - e que em sentido original é a economia.

A esfera privada, pela própria palavra que a nomeia, ao mesmo tempo em que protege o homem do mundo comum resguardando-o na intimidade, também o priva "das mais altas e mais humanas capacidades do homem" (op. cit. p. 48), de ver e ouvir os outros e ser visto e ouvido por eles (op. cit. p. 67). Se isto, por um lado, priva o homem de agir entre os outros homens, por outro é o que possibilita que haja a casa, a morada humana que, separando do restante do mundo um espaço de aconchego, permite ao homem dar ouvidos à sua solidão. Sem a vivência da própria solidão num espaço abrigado onde se possa ouvir o silêncio, qualquer outra experiência humana, do homem consigo mesmo ou com os outros homens, não teria profundidade. Como nos diz Bachelard, “(...) todos os espaços das nossas solidões passadas, os espaços em que sofremos a solidão, desfrutamos a solidão, desejamos a solidão, comprometemos a solidão, são indeléveis em nós. (...) esses espaços de (...) solidão são constitutivos" (1993, p.29), constituição esta que se configura como o lastro que pesa ao homem a possibilidade de sua profundidade. Nas palavras de Arendt,

Uma existência vivida inteiramente em público, na presença de outros, torna-se, como diríamos, superficial. Retém a sua visibilidade, mas perde a qualidade resultante de vir à tona a partir de um terreno mais sombrio, terreno este que deve permanecer oculto a fim de não perder sua profundidade num sentido muito real e não subjetivo. 0 único modo eficaz de garantir a sombra de que deve ser escondido 
contra a luz da publicidade é a propriedade privada - um lugar só nosso, no qual podemos nos esconder. (2007, p. 81)

Também o amor, que retira o homem do mundo e da relação com os outros ${ }^{15}$, só pode se preparar e se dar na esfera privada, no abrigo do mundo, região de aconchego onde, só aí, há espaço para a intimidade. "Na verdade, as paixões cozinham e recozinham na solidão. É encerrado em sua solidão que o ser de paixão prepara suas explosões ou seus feitos." (BACHELARD, 1993, p.29)

As relações amorosas no contexto da prisão são sempre de alguma forma comprometidas. Quando perdura durante o aprisionamento uma relação que já existia antes, ela fica limitada à correspondência por carta (e ao contato ilícito por telefone celular) e ao dias de visita, dois por semana, nos quais o visitante precisa se submeter à fila de entrada, à revista e ao detector de metais para as poucas horas de "visita íntima", como é chamada. Na semi, a visita íntima nem tem espaço onde acontecer. Muitas relações terminam; algumas poucas, de modo surpreendente, surgem, por exemplo quando algum parente de algum preso conhece outro durante uma visita. As relações heterossexuais ficam completamente impossibilitadas no dia a dia prisional, já que o contato entre homens e mulheres é proibido. Não é raro quem questione a própria sexualidade de antes de ser preso e experimente, por exemplo, relações homossexuais inéditas, o que muitas vezes pode se configurar como mais um dos atentados infligidos pela prisão à identidade com a qual uma pessoa se conhecia a si mesma.

15 Conforme Arendt: "Dada a sua paixão, o amor destrói aquela mediação que estabelece uma relação entre nós e os outros, e deles nos separa. Enquanto dura o seu fascínio, a única mediação que pode inserir-se entre dois seres que se amam é o filho, produto do amor. 0 filho, essa mediação com a qual agora os amantes passam a relacionar-se e que possuem em comum, é representativo do mundo porque também os separa; é uma indicação de que acrescentarão um novo mundo ao mundo existente. É como se, através do filho, os amantes retornassem ao mundo do qual o amor os expulsou. Mas essa nova mundanidade, o único resultado possível e o único final possivelmente feliz de um caso de amor, é, de certa forma, o fim do amor, que terá de dominar novamente os dois parceiros ou transformar-se em outra modalidade de convivência. Por natureza, o amor é extramundano e é por esta razão - e não por ser tão raro - que é não apenas apolítico mas anti-político, talvez a mais poderosa das forças humanas anti-políticas." (2007, p. 254) 
A esfera pública, distintamente, é o próprio mundo, "na medida em que é comum a todos nós e diferente do lugar que nos cabe dentro dele" (ARENDT, 2007, p. 62). É onde os homens, plurais, se encontram e podem se exercer em sua individualidade e singularidade. É também o "que é capaz de absorver e dar brilho através dos séculos a tudo o que os homens venham a preservar da ruína natural do tempo" (op. cit. p. 65). 0 mundo, por ser através dos tempos onde os homens se encontram, é o palco das histórias individuais de cada um. "Que toda vida individual entre o nascimento e a morte possa ser narrada como uma estória com começo e fim é a condição pré-política e pré-histórica da história, a grande estória sem começo nem fim." (ARENDT, 2005, p. 192) É na esfera pública, então, que acontece a história.

De forma sintética, Arendt nos esclarece que

Embora a distinção entre o privado e o público coincida com a oposição entre a necessidade e a liberdade, entre a futilidade e a realização e, finalmente, entre a vergonha e a honra, não é de forma alguma verdadeiro que somente o necessário, o fútil e o vergonhoso tenham o seu lugar adequado na esfera privada. 0 significado mais elementar das duas esferas indica que há coisas que devem ser ocultadas e outras que necessitam ser expostas em público para que possam adquirir alguma forma de existência. (op. cit. pp. 83-84)

Assim, o público e o privado, as esferas em que o homem percorre sua vida, são-lhe, cada uma à sua maneira, essenciais. A prisão, por ser o lugar onde vivem alguns homens, ainda que em condições e por razões específicas, poderia ser pensada a partir desta distinção entre as esferas pública e privada. Ambas, no entanto, parecem estar ausentes da prisão ou, a partir de outra perspectiva, não é possível qualificar o mundo da prisão nem como público nem como privado mas apenas encontrar no contexto do aprisionamento alguns aspectos de cada uma das esferas.

A vida privada é muito comprometida no contexto do aprisionamento, porque ali não se pode ter nada que pertença de fato a alguém, muito menos um lugar próprio. No ambiente prisional como um todo e na cela mais especificamente, não há nada que o detento possa chamar de seu, a não ser poucos ínfimos pertences - e chega a impressionar como a organização zelosa de produtos de higiene pessoal, 
ou a disposição cuidadosa de recortes de revista na parede parece ser uma tentativa desesperada de estabelecer um "canto", no sentido de lugar onde o íntimo possa se revelar. Cartas e fotos assumem o estatuto de preciosidade onde nenhum outro objeto traz em si a aura de acolhimento em que os objetos de cada casa são envoltos.

A prisão é, em dois sentidos, um lugar de ausência de solidão. Num sentido concreto, "De modo geral, evidentemente, o internado nunca está inteiramente sozinho; está sempre em posição em que possa ser visto e muitas vezes ouvido por alguém, ainda que apenas pelos colegas de internamento." (GOFFMAN, 2013, p. 32). Em outro sentido, a ausência de aconchego e de intimidade na falta de um espaço próprio desmancham continuamente a fecundidade possível de se estar só.

A ausência do âmbito privado impossibilita muita coisa, além da própria privacidade. Hannah Arendt, pensando acerca da vida privada, retoma a sacralidade dos limites com que os antigos cercavam suas propriedades, “(...) não (pelo) respeito pela propriedade privada como a concebemos, mas (pelo) fato de que, sem ser dono de sua casa, o homem não podia participar dos negócios do mundo porque não tinha nele lugar algum que lhe pertencesse." (2007, p. 39)

Para os mesmos antigos,

A privatividade era como que o outro lado escuro e oculto da esfera pública; ser político significava atingir a mais alta possibilidade da existência humana; mas não possuir um lugar próprio e privado (como no caso do escravo) significava deixar de ser humano. (op. cit. p. 74)

A "privação do privado" na prisão dificulta que até mesmo a história que levou cada um até ali possa ser apropriada biograficamente, o que poderia ser visto como o único "benefício" do encarceramento, como uma pausa nos acontecimentos (que de fato não se passa, como discutirei adiante) para que os anteriores pudessem ser rememorados.

Na prisão a satisfação das necessidades está previamente garantida. 0 detento quase nunca precisa se esforçar para garantir a própria alimentação, não tem casa ou nada próprio de que cuidar. Não trabalha, no sentido arendtiano do termo, exceto de modo muito primitivo: alimenta-se do que lhe é servido, veste-se 
da maneira como é obrigado a fazer, cuida apenas na medida do possível da própria higiene. Não tem que carregar o ônus da própria vida, o que, em todos os casos em que isso acontece, tem consequências muito significativas, como nos coloca Arendt:

O preço da eliminação do ônus da vida era enorme, e de modo algum se restringia à violenta injustiça de forçar parte da humanidade a manter-se na treva da dor e da necessidade. Como essa treva é natural, inerente à condição humana - e somente o ato de violência, quando um grupo de homens tenta libertar-se dos grilhões que nos prendem a todos à necessidade e à dor, é produto do homem -, o preço da absoluta libertação da necessidade é, em certo sentido, a própria vida, ou, antes, a substituição da vida real por uma vida vivida por outros. (op. cit., p. 132)

A própria experiência de felicidade fica comprometida quando o homem fica privado da possibilidade de satisfazer ele mesmo as próprias necessidades através da ciclicidade do trabalho, seja pela miséria, seja porque isso já está previamente garantido, seja pela doença:

Não há felicidade nem contentamento duradouros para os seres humanos fora do círculo prescrito de dolorosa exaustão e prazerosa regeneração. Tudo o que lança este ciclo em desequilíbrio - a miséria, onde a exaustão é seguida pela penúria; ou uma vida inteiramente sem esforço, onde o tédio toma o lugar da exaustão; e onde os moinhos da necessidade, do consumo e da digestão trituram até a morte, inclementes, um corpo humano impotente - arruína a felicidade elementar que resulta do estar vivo. (ARENDT, 2005, p. 183)

Por ser um hospital ao mesmo tempo que uma prisão, para o Centro Hospitalar do Sistema Penitenciário vão os detentos que tenham algum tipo de enfermidade e que necessitam de cuidados direcionados a ela. Nesse sentido, podese dizer que o cuidar de si próprio como doente de alguma maneira devolve a quem está ali a necessidade de cuidado com a própria vida ou o "ônus da vida", como o denomina Arendt (embora a doença possa, ela mesma em alguns casos, impedir o acontecer da regeneração). É como se, paradoxalmente, o adoecimento, no contexto de se estar preso, pudesse ser a única maneira através da qual pulsasse a vida, ainda que em alguns casos prestes a se alienar, já que o esforço para a própria manutenção está extinto. 
0 trabalho, no sentido mais amplo do termo, assume na prisão sentidos diferentes do trabalho na rua. Goffman, comparando o trabalhar dentro e fora das instituições totais, nos diz que

Nas condições usuais de vida de nossa sociedade, a autoridade do local de trabalho pára quando o trabalhador recebe um pagamento em dinheiro; o fato de gastá-lo em casa ou em local de diversões é um problema pessoal do trabalhador e constitui um mecanismo pelo qual a autoridade do local de trabalho é mantida dentro de limites bem restritos. Mas, dizer que os internados de instituições totais têm todo o dia determinado, para eles equivale a dizer que todas as suas necessidades essenciais precisam ser planejadas. Portanto, qualquer que seja o incentivo dado ao trabalho, esse incentivo não terá a significação estrutural que tem no mundo externo. Haverá diferentes motivos para o trabalho e diferentes atitudes com relação a ele. (2013, pp. 20-21)

A principal motivação de trabalhar na prisão é a passagem mais depressa do tempo, no duplo sentido disso, ou seja, preencher o tempo com alguma atividade que o faça parecer transcorrer mais veloz e diminuir o tempo da pena. Trabalhar dentro do estabelecimento prisional, além da remuneração em dinheiro, frequentemente gasta com dívidas de drogas e do crime, dá direito "à remição da pena, na proporção de três dias trabalhados para um dia a menos de prisão" (segundo site do Tribunal de Justiça do Distrito Federal e dos Territórios). No CHSP, não há trabalho, exceto pela divisão de tarefas organizada dentro de cada ala, como separar as roupas para lavar, avisar os internos do atendimento, etc. O CHSP, por ser um hospital, é lugar de convalescer ou de morrer - morte que se tenta fazer acontecer dignamente, num esforço que costuma ter direção oposta à da prisão.

Esse tempo que precisa ser passado mais depressa, com o qual se quer liquidar, é sentido, na prisão, como tempo morto:

(...) existe um imenso sentimento de que o tempo passado no estabelecimento é tempo perdido, destruído ou tirado da vida da pessoa; é tempo que precisa ser "apagado"; é algo que precisa ser "cumprido", "preenchido" ou "arrastado" de alguma forma. (...) Este tempo é algo que foi posto entre parênteses na consciência constante, e de uma forma que dificilmente se encontra no mundo externo. Por isso, o internado tende a sentir que durante a sua estada obrigatória - sua sentença - foi totalmente exilado da vida. É neste contexto que podemos avaliar a influência de uma sentença indefinida ou de sentença muito longa. (GOFFMAN, 2013, pp. 64-65) 
Concretamente, a dificuldade em manter laços sociais com as pessoas que eram de sua convivência e a impossibilidade de se levar da prisão para o mundo externo coisas que teriam tornado proveitoso o tempo de reclusão, como "dinheiro, formação de ligações conjugais, certidão de estudos realizados" (op. cit. p. 65), ressaltam o caráter morto e perdido do tempo vivido detrás de grades.

0 mundo comum, público, também parece estar ausente da prisão - a retirada do detento do mundo onde vive constitui, aliás, a razão de ser do encarceramento, seja para proteger a sociedade de quem supostamente lhe possa oferecer riscos, seja para que alguém pague pelo que fez ${ }^{16}$, sendo privado de estar em seu próprio mundo. Arendt nos coloca que "no centro de um julgamento só pode estar aquele que fez algo (...), e se ele sofre, deve sofrer pelo que fez, não pelo que os outros sofreram" (1999, p. 19), ou seja, a palavra vingança não está dentro do significado da justiça, ainda que infelizmente ambas sejam com frequência confundidas. Outra confusão comum é a crença de que o castigo da sentença servirá para impedir futuros crimes, seja por arrependimento, seja para que não se esteja sujeito a nova pena. Novamente, Arendt nos esclarece:

Faz parte da própria natureza das coisas humanas que cada ato cometido e registrado pela história da humanidade fique com a humanidade como uma potencialidade, muito depois da sua efetividade ter se tornado coisa do passado. Nenhum castigo jamais possuiu poder suficiente para impedir a perpetração de crimes. (op. cit. p. 296)

\footnotetext{
16 Segundo Arendt, "Os processos criminais, uma vez que são obrigatórios e devem ser iniciados mesmo que a vítima prefira perdoar e esquecer, repousam em leis cuja "essência (...) é que o crime não é cometido só contra a vítima, mas primordialmente contra a comunidade cuja lei é violada. 0 malfeitor é levado à justiça porque seu ato perturbou e expôs a grave risco a comunidade como um todo, e não porque, como nos processos civis, indivíduos foram prejudicados e têm direito à compensação. A compensação efetivada nos casos criminais é de natureza inteiramente diferente; é o corpo político em si que exige "compensação", e é a ordem pública que foi tirada de prumo e tem de ser restaurada, por assim dizer. Em outras palavras, é a lei, e não a vítima, que deve prevalecer." (1999, p. 283)
} 
0 "castigo" de ser preso, ainda mais num sistema carcerário tão peculiar como o brasileiro, controlado em muitas instâncias pelas próprias organizações criminosas que nele deveriam estar para serem afastadas da sociedade, mas que justamente através dele com ela fazem ponte, não impede a reincidência do crime; pelo contrário, parece incentivá-la, por motivos que tentarei esboçar adiante. Não posso deixar de mencionar os inúmeros casos imensamente absurdos de pessoas inocentes que têm de aguardar seu julgamento presas (o que fere a presunção da inocência garantida pela Constituição Brasileira de 1988), ou aqueles de gente que espera tanto tempo para ser julgado que a demora é maior que o tempo que a pessoa deveria permanecer na prisão, caso fosse condenada, ou ainda aqueles em que, a meu ver, a não interpretação do crime acaba permitindo a condenação a uma pena desproporcional ao delito (cito o exemplo extremo de um homem que foi preso por ter furtado um frasco de perfume e cuja soltura tardou oito meses; cito o exemplo de um homem preso há mais de cinco anos por ter furtado uma bicicleta, e que depois de preso teve a pena aumentada por "faltas" cometidas na prisão. Este homem está com câncer, internado no CHSP, de onde dificilmente sairá. E poderia seguir citando infinitos exemplos).

Mas não são só as peculiaridades do sistema carcerário brasileiro que acabam por perpetuar a criminalidade ao invés de diminui-la. Experiências características de qualquer prisão em que castigos internos, muitas vezes rigorosos, são perpetrados pela chamada equipe dirigente ou mesmo pela sanção das leis internas dos detentos, podem dar conta de que isso ocorra. Como nos mostra Goffman,

(...) se os internados são pessoas acusadas de terem cometido algum crime contra a sociedade, o internado recém-chegado, embora algumas vezes realmente não tenha qualquer culpa, pode chegar a compartilhar os sentimentos de culpa de seus companheiros, bem como suas complexas defesas contra tais sentimentos. Tendem a desenvolver-se um sentido de injustiça comum e um sentido de amargura contra o mundo externo, o que assinala um movimento importante na carreira moral do internado. (...) Por seu raciocínio, depois de um delinquente ter sido submetido a castigo injusto ou excessivo, bem como a tratamento mais degradante que o prescrito pela lei, passa a justificar o seu ato - o que não podia fazer quando o cometeu. Decide descontar o tratamento injusto na prisão, e a vingar-se, na primeira oportunidade, através de outros crimes. Com essa decisão, torna-se um criminoso. (2013, p. 56) 
Voltando à perda do mundo comum, público, que acontece em se estando na prisão, seu caráter de pena se dá primordialmente porque o dia a dia próprio é completamente ceifado. As ruas conhecidas, as pessoas com quem se cruza ao andálas, a experiência de convívio na comunidade em que se vivia, as coisas do mundo, enfim, são impedidas e viram, se persistem, memória. Mas a memória das coisas de fora tampouco cabe dentro dos muros. Na prisão, muitos detentos dizem, só se fala de crime, que acaba se tornando, então, a única coisa real. Se a realidade das nossas coisas é garantida através de seu aparecimento para os outros ${ }^{17}$, na prisão é então o crime o que se torna real, relegando às lembranças da vida de fora a condição de um passado esfumaçado, longínquo e praticamente inacessível.

Saindo novamente por um momento do contexto da prisão, voltarei a caracterizar a ação para depois pensá-la novamente no aprisionamento. Agir ${ }^{18} \mathrm{e}$ falar são as maneiras através das quais nos inserimos no mundo humano, público, exercendo a alteridade e a distinção que se tornam no homem singularidade. A singularidade, por sua vez, a exercemos quando realizamos nossa capacidade de, por nossa própria iniciativa, iniciar algo novo, que só poderia mesmo ter sido iniciado por quem o iniciou e mais ninguém. Isso é a liberdade: a faculdade do homem de, agindo, começar algo que antes e sem ele como ser singular não poderia nunca ter sido iniciado (como discutiremos mais adiante). Agindo e falando, o homem revela quem ele mesmo é, mesmo que isso só apareça para os outros, no final de cada história e não a ele mesmo, e estabelece relações, violando limites e extrapolando fronteiras. Por acontecer entre os homens e não ser condicionada meramente pelo mundo durável das coisas, a ação se multiplica em teias, é

17 Quanto à realidade permitida pela presença dos outros, nos diz Arendt que "Toda vez que falamos de coisas que só podem ser experimentadas na privatividade ou na intimidade, trazemo-las para uma esfera na qual assumirão uma espécie de realidade que, a despeito de sua intensidade, elas jamais poderiam ter tido antes. A presença de outros que vêem o que vemos e ouvem o que ouvimos garante-nos a realidade do mundo e de nós mesmos." (2007, p. 60)

18 Este parágrafo contém uma tentativa de resumo da fenomenologia da ação de acordo com $A$ Condição Humana. 
extremamente frágil e não confiável e configura processos ilimitadamente imprevisíveis, além de ser também irreversível. A força do processo da ação nesta teia vai aumentando num prolongamento que faz com que um único ato possa ter consequências - imprevisíveis e irreversíveis - até o fim dos tempos. 0 remédio para essas consequências que podem ser catastróficas, dadas suas imprevisibilidade e irreversibilidade, está também no escopo da ação: são, respectivamente, as faculdades humanas de prometer e perdoar. Explica-nos Arendt que

0 perdão diz respeito ao passado e serve para desfazer o que foi feito, enquanto que o compromisso através de promessas serve para estabelecer ilhas de segurança no oceano de incerteza futura, sem as quais nem mesmo a continuidade, sem falar de todo tipo de durabilidade, jamais seria possível na relação entre os homens. Sem sermos perdoados, liberados das consequências do que fizemos, a nossa capacidade de agir estaria, por assim dizer, confinada a um único ato do qual jamais nos recuperaríamos; permaneceríamos as vítimas de suas consequências para sempre (...). Sem estarmos obrigados ao cumprimento de promessas, nunca seríamos capazes de atingir aquele grau de identidade e de continuidade que, juntas, produzem a "pessoa" acerca de quem uma estória pode ser contada; cada um de nós estaria condenado a vagar desamparado e sem direção na escuridão de seu próprio coração solitário, enredado em suas contradições e equívocos e em seus humores sempre em mudança. (2005, pp. 193-194)

Voltando agora ao contexto do aprisionamento, é possível dizer que ele tende a aproximar do comportamento, dos automatismos, e afastar do agir, através da imposição de inúmeras regras de conduta e da retirada do mundo onde a ação pode se dar. Quanto às regras de conduta, também o disse Goffman que

\begin{abstract}
Numa instituição total (...), os menores segmentos da atividade de uma pessoa podem estar sujeitos a regulamentos e julgamentos da equipe diretora; a vida do internado é constantemente penetrada pela interação de sanção vinda de cima, sobretudo durante o período inicial de estada, antes de o internado aceitar os regulamentos sem pensar no assunto. Cada especificação tira do indivíduo uma oportunidade para equilibrar suas necessidades e seus objetivos de maneira pessoalmente eficiente, e coloca suas ações à mercê de sanções. Violenta-se a autonomia do ato. (2013, p. 42)
\end{abstract}

Se, no entanto, a ação é o que há de mais humano no homem, prevalece inevitável o questionamento de como se pode, dessa maneira, tornar uma pessoa mais humana na prisão - outro dos errôneos pressupostos velados do aprisionar. 0 que aparece é sempre justamente o contrário. Não estou, com isto, sugerindo que os 
crimes não devam ser julgados e punidos, nem que devam ser perdoados. Já que se falou em perdão, este sim caberia, se fosse o caso, à vítima conceder, o que não retiraria da Justiça a necessidade de cumprir seu papel de julgar e condenar, como já discutimos anteriormente. As consequências dos tipos de pena existentes e principalmente da pena de reclusão, que ao que parece perpetuam ainda mais a criminalidade, é que ao meu ver precisariam ser repensadas, pois acabam construindo uma teia de ações, infinita, imprevisível e irreversível, dentro do mundo do crime.

"A ação não apenas mantém a mais íntima relação com o lado público do mundo, comum a todos nós, mas é a única atividade que o constitui." (ARENDT, 2007, p. 210). Estaria o agir impossibilitado de se dar na prisão já que é com muitas ressalvas que se pode caracterizar o "público" no contexto do aprisionamento, e já que parece haver uma constante aproximação do comportamento através das mencionadas regras de conduta? Isto significaria também que, de encontro à noção comum de se estar preso e se estar em liberdade, a liberdade seria de fato impossível na prisão, pois ela é intrinsecamente relacionada ao agir. Na prisão as pessoas tem de se locomover da mesma maneira - com a cabeça baixa e os braços para trás, tem que vestir as mesmas roupas, falar com os superiores com o mesmo tratamento na linguagem, assim como com seus iguais (variando apenas a linguagem que se fala quando com os superiores e com os iguais); se "a tentativa de eliminar a pluralidade equivale sempre à supressão da própria esfera pública" (op. cit. p. 233), ainda sob este aspecto há prejuízo do que é possível haver de público na prisão.

A prisão é o marginal absoluto porque não pertence à esfera privada tampouco à pública. Colocar o homem no que não é um lugar nem na sociedade nem na política é como que a tentativa de, retirando-o temporária mas completamente do mundo possível dos homens, calá-lo e abafá-lo; é submetê-lo, se isso fosse possível, a uma morte reversível - mas que, sob alguns aspectos, pode ser irreversível. Um homem que não tenha que garantir a própria sobrevivência e que não possa atuar publicamente - que esteja impossibilitado de agir -, é um homem que está morto. 
O mundo do crime e sua configuração como crime organizado talvez sejam a tentativa de persistir num mundo comum, quando se está excluído dele. Poderia também se pensar o surgimento do PCC, o Primeiro Comando da Capital, como um resgate de ação humana e como um gesto político, considerando apenas o que é tido como seu marco inicial, o massacre do Carandiru em 1992 ${ }^{19}$. O que o crime organizado intenciona de fato, porém, longe de ser uma luta política legítima por direitos, seja dos detentos, seja dos que estejam sujeitos a algum tipo de humilhação, são, em última análise, bens econômicos; e como originalmente o econômico diz respeito à manutenção da sobrevivência e não à ação humana, uma organização que tenha somente tal tipo de objetivo não pode ser política. O PCC pode ter poder no sentido de realizar ações conjuntas, de vários homens, já que, segundo Hannah Arendt, "o poder corresponde, antes de mais nada, à condição humana da pluralidade." (2007, p. 213) No entanto, a mesma autora nos diz que

0 poder só é efetivado enquanto a palavra e o ato não se divorciam, quando as palavras não são vazias e os atos não são brutais, quando as palavras não são empregadas para velar intenções mas para revelar realidades, e os atos não são usados para violar e destruir, mas para crias relações e novas realidades. (op. cit. p. 212)

Por já haver agido brutalmente e enquanto utilizar da violência como meio para obter fins econômicos e não políticos, o PCC, mesmo que tenha imensa capacidade destrutiva, é impotente, pois existe "a combinação política, nada incomum, de força e impotência." (op. cit. p. 214) A aspiração da onipotência sempre implica a destruição da pluralidade (loc. cit.) e, assim, da condição primeira de poder.

Apesar das elocubrações anteriores creio não poder chegar a uma conclusão definitiva acerca da ação do PCC ser ou não política. Ao pender para um lado o outro sempre parece despontar em ambiguidades e desconsiderá-las poderia ser raso e

\footnotetext{
19 Está no estatuto do PCC: "Temos de permanecer unidos e organizados para evitarmos que ocorra novamente um massacre semelhante ou pior ao ocorrido na Casa de Detenção em 2 de outubro de 1992, onde 111 presos foram covardemente assassinados, massacre esse que jamais será esquecido na consciência da sociedade brasileira. Porque nós do Comando vamos sacudir o sistema e fazer essas autoridades mudar a política carcerária, desumana, cheia de injustiça, opressão, tortura e massacre nas prisões." (BARBATO JÚNIOR, 2007, pp. 85-86)
} 
precipitado. 0 surgimento do PCC certamente diminuiu as agressões gratuitas a que os detentos eram submetidos e instaurou na prisão regras que, apesar de rígidas como toda regra, surgiram a partir das necessidades dos presos e não da equipe dirigente e relativizaram as que eram impostas pela administração penitenciária. Isto continua presente, mesmo que pareçam ser os bens econômicos seus objetivos finais. 
O CAMINHO PARA PERTO DE QUEM ESTÁ DETRÁS DAS GRADES

Quando, nos primeiros dias de meu trabalho no hospital penitenciário, percebi que, para que eu pudesse entrar, algumas coisas em mim deveriam sair, ou ser momentaneamente deixadas de lado, talvez eu já estivesse dando passos no caminho fenomenológico com o qual trilhei esta investigação. Voltar às coisas mesmas - a máxima da fenomenologia - exige antes de tudo interrogar os preconceitos, pressupostos teóricos, ideias preconcebidas, colocando "entre parênteses" toda a armadura que nos serve para proteger do "“frio na barriga" de não estarmos amparados e protegidos por um procedimento previamente estipulado" (CLINI, 2010, p. 8), "frio na barriga” que é o indício da abertura desnuda a partir da qual se pode verdadeiramente aproximar de, para compreender a, alguém. É, então, a partir de um incômodo que se inicia: o incômodo de ainda não haver caminho, e de não se saber, a cada passo que constrói um trilhar, para que fim a direção em que estamos indo nos vai levar. "Todo questionamento é uma procura. Toda procura retira do procurado sua direção prévia." (HEIDEGGER, 1988, p. 30) Há que se sustentar no incômodo; aguentar a "demora" do acontecer, "manter-se perguntando por mais tempo, até que as respostas surjam do que vem ao nosso encontro; é preciso aguentar permanecer no aberto, mesmo que se sinta pressionado a encerrar logo o assunto." (CLINI, 2010, p. 9)

Estar nesta abertura desnuda não significa estar alheia à existência de teorias como forma de se acercar das coisas, mas sim saber que nenhuma teoria previamente formulada é capaz de dar conta de forma suficiente e definitiva de algo como uma pessoa e a maneira como ela vive o que vive, esteja ela presa, "em liberdade", sadia ou adoecida.

Segundo Martins e Bicudo,

Na pesquisa fenomenológica, o investigador, de início, está preocupado com a natureza do que vai investigar, de tal modo que não existe, para ele, uma compreensão prévia do fenômeno. Ele não possui princípios explicativos, teorias, ou qualquer indicação definidora do fenômeno. Inicia seu trabalho interrogando o fenômeno. [...] O fenomenólogo respeita as dúvidas existentes sobre o fenômeno pesquisado e procura mover-se lenta e cuidadosamente de forma que ele possa 
permitir aos seus sujeitos trazerem à luz o sentido por eles percebidos sobre o mesmo (1989, p. 92).

Heidegger, desvendando o termo fenômeno, nos diz que ele deriva de phainestai, o que se mostra ou se revela e traz em si o radical pha, que carrega o sentido de luz, claridade ou o que, iluminando, permite que algo possa se revelar e tornar visível em si mesmo (2005, p.58). Isto é diferente de ver superficialmente, como muitas vezes se entende a fenomenologia. Conforme Ales Bello,

em geral, [fenomenologia] significa análise dos fenômenos, mas esta análise poderia ser reduzida em termos de uma descrição superficial, sendo que em muitos casos é esta a maneira de entender a fenomenologia, na psicologia. Todavia, a fenomenologia (...) vai muito além, pois põe-se a perguntar: eu vejo algo, mas o que é este algo que eu vejo? (2004, pp. 106-107)

Tal análise dos fenômenos seria trazer à luz o que, em cada fenômeno, o fundamenta e constitui, em si mesmo, o seu sentido. Ora, mas em se tratando de algo que já está ali, no fenômeno, por que se deveria esforçar em fazê-lo mostrar-se? Heidegger nos diz que, num sentido privilegiado, o que deveria se chamar de fenômeno é, em geral, justamente o que não se mostra diretamente e "sim se mantém velado frente ao que se mostra (...), mas, ao mesmo tempo, pertence essencialmente ao que se mostra (...) a ponto de constituir o seu sentido e o seu fundamento." (2005, p. 66)

A partir do pensar original de Husserl acerca das vivências e da intencionalidade através do que então se iniciou como fenomenologia, abriu-se a possibilidade (ou se a retomou) de desenvolver uma compreensão do outro que não a explicação ou a classificação. Nestes dois casos, ao invés de uma aproximação, o que ocorre é justamente o oposto pois ao explicar utiliza-se algo que se encontra fora do que se mira como maneira de entendê-lo, caso das teorias acerca das coisas, e ao classificar, generaliza-se e, portanto, afasta-se do que se está mirando. Não pretendo explicar ou classificar com esta investigação. É a aproximação da privação da liberdade, através da compreensão, o que pretendo fazer.

O homem é ser-aí (Da-sein, como o nomeia Heidegger): é no mundo. Isto não significa simplesmente que o homem está no mundo ao lado de todas as outras 
coisas mas que é lançado no mundo, no fora de si mesmo, que o homem é, e se encontra; e que é ali, fora de si, que é si mesmo. Heidegger nos esclarece:

A afirmação de que o ser-aí "se" dá a entender a partir de "seu" mundo significa, então, o seguinte: neste vir-ao-encontro-de si a partir do mundo, o ser-aí se temporaliza como um si mesmo, isto é, como um ente que foi entregue a si mesmo para ser. (2008, p. 169)

Porque o homem é-no-mundo, a aproximação da vivência do estar encarcerado é também a aproximação da prisão, que é simultaneamente seu mundo atual e a retração de seu mundo anterior, do qual foi forçadamente banido. Assim, é impossível destacar os relatos dos encontros de seu contexto, de seu lugar de origem: o corredor psicossocial, onde ocorrem os atendimentos de portas abertas, ou os leitos de enfermaria ou as celas-leito dentro das alas; impossível destacar os relatos do mundo da prisão, com todas as suas peculiaridades e com tudo o que ele significa, limita, interfere, modifica instante a instante para quem ali, preso, vive. Para falar do e com o homem preso, vem inevitavelmente junto a prisão. Para falar do aprisionamento vem inevitavelmente junto o homem preso. Vejo, assim, ser necessário

ouvir aqueles que, por terem vivido a situação, são os únicos capazes de dar testemunho verdadeiro dela, testemunho este que escape ao nível da pura especulação abstrata, podendo nos aproximar um pouco mais das significações verdadeiras que ela engendra. (NAFFAH NETO, 1985, p. 69)

Isto significaria a aproximação da privação da liberdade através do encarceramento e do adoecimento vivenciado pelas pessoas que estarão presentes nesta investigação, mas esconde outra possibilidade: a de que eu, ouvinte do que estas pessoas me possam dizer acerca do que vivenciam como privação de liberdade, possa ser tocada por quem se mostra aprisionado diante de mim através da liberdade da qual, de alguma forma, eu também talvez esteja privada. Stein nos diz que

(...)se queremos saber o que é o homem, temos que nos colocar do modo mais vivo possível na situação em que experimentamos a existência humana, ou seja, o que 
dela experimentamos em nós mesmos e em nossos encontros com outros homens. (2007, p. 33. Tradução livre minha)

Não pretendo entrevistar, livre, pessoas que se mostrem presas na minha frente $^{20}$; gostaria de propiciar e participar da realização de conversas entre aprisionados em alguma instância, em alguma esfera - os internos detentos e eu. Safra nos ilumina essa possiblidade quando nos apresenta a concepção ontológica de Sobórnost, que assinala cada ser humano como a "singularização da vida de muitos" (2004, p. 43):

(...) sendo o registro (de Sobórnost) o ontológico, mantemos a situação aberta às condições fundamentais para o habitar do homem no mundo. (...) Sobórnost implica que a situação chamada transferencial esteja aportada na solidariedade e na amizade, decorrentes da consciência de que o Outro que nos procura está irmanado a nós, pois estamos em meio ao mesmo destino: a condição humana. (...) Solidariedade e amizade significam aqui um princípio ético fundamental, só possível quando estamos realmente humildes (voltados ao húmus-terra), situação que ocorre ao estarmos nus de qualquer onipotência. Então compreendemos que nossa biografia é diferente da de nosso paciente, mas somos companheiros de viagem pelas intempéries da existência. Posicionados desta forma, estaremos em comunidade de destino, condição fundamental para o nascer, para o caminhar pela vida e para o morrer de qualquer ser humano! (op. cit. p. 147)

20 Durante a apresentação do projeto desta pesquisa na disciplina "Psicologia Clínica: atividades voltadas para a pesquisa na área", o Professor Gilberto Safra apontou a diferença entre a realização de entrevistas e de encontros nos quais eu também estivesse implicada, atravessada pela questão, eu mesma, da liberdade e de sua privação. 


\section{DIFICULDADES, IMPOSSIBILIDADES E SAÍDAS METODOLÓGICAS}

Tardou onze meses para que eu recebesse uma resposta afirmativa de que poderia realizar minha investigação como eu a havia pensado: gravando conversas entre mim e os presos internados em que eu lhes perguntasse acerca de como vivem as formas de privação de liberdade que recaem sobre eles. Inicialmente eu havia observado que algumas dessas formas eram muito recorrentes no hospital penitenciário e pensei então em conversar com seis internos que vivessem cada uma delas e as representassem paradigmaticamente. Eles e as respectivas privações seriam: um interno com alguma doença clínica ou cirúrgica de bom prognóstico, que não se apresentasse, em si, como privativa de liberdade para que eu pudesse "isolar" o fator do encarceramento como privação de liberdade e pudesse, assim, aproximarme, junto e através do interno, só desse fator; um interno com paraplegia ou tetraplegia, bastante frequentes ali, resultados muitas vezes de assaltos mal sucedidos e dos tiros suscitados por eles, para que a impossibilidade de locomoção, com todas as suas consequências e repercussões, pudesse ser aproximada como privação de liberdade naquele momento e também no futuro, já que a detenção sempre tem um tempo e um fim determinados, diferente das plegias, que podem ser definitivas; um interno agudamente psicótico, para que a privação da abertura existencial e da "possibilidade de acontecer do "si mesmo", da possibilidade do mundo se dar em seu ser livre" (VALVERDE, 2011, p. 142), presentes na psicose, pudesse ser acercada; um interno que estivesse vivendo a proximidade sabida ou adivinhada de seu fim através de uma doença terminal, para que o tempo limitado pudesse aparecer como a liberdade privada; um interno adicto em substâncias psicoativas, para que a impossibilidade da escolha constitutiva da adição pudesse ser evidenciada como privação de liberdade, e um interno no seguro, enfermaria ou cela reservada àqueles com diferenças com a facção criminosa atuante no hospital penitenciário, o PCC, configurando o que poderia ser descrito como estar preso dentro da prisão.

Algumas dificuldades logo apareceram. A primeira: a grande rotatividade que há no hospital, que combinada com a longa demora para a aprovação do meu 
projeto (que detalharei abaixo) fez com que muitas pessoas com quem intuí poder acercar-me das questões acima recebessem alta hospitalar antes da possibilidade dessa conversa específica ser real.

Depois, percebi que a divisão de "privações de liberdade" que eu havia feito era demasiado didática e completamente atropelada pelo que eu presenciava no CHSP. Diversas combinações das "minhas" privações nos internos, como pacientes paraplégicos e psicóticos e no seguro, ou pacientes com dependência química e doença terminal, ou muitas outras possibilidades combinadas de impossibilidades, ou a presença maciça de uma delas (a maioria dos pacientes do CHSP são ou foram usuários de substâncias psicoativas), fizeram-me enxergar que, além de não ser possível "isolar" cada um desses fatores, tampouco era necessário ou desejado; percebi que a liberdade da qual o indivíduo foi privado em cada uma das complexas situações, por mais variada que aparecesse, era muito possivelmente apenas uma. Vi também que não havia sentido algum em "isolar" o encarceramento como fator de privação de liberdade, já que esta é uma pesquisa qualitativa, aberta e não necessita de um "grupo controle" contra o qual comparar outros resultados. Decidi então escolher alguns internos de número a princípio não definido que pudessem, falandome de suas vivências, fazer com que nos aproximássemos, eles e eu, da liberdade através de suas privações. Os prazos destinados à dissertação e outros fatores dos quais falarei adiante fizeram com que o número de relatos trazidos a esta pesquisa fosse quatro.

A maneira como elaborei meu projeto, dividindo didaticamente em grupos as diferentes formas de privação de liberdade e considerando incluir entre os "entrevistados" um grupo que poderia ser classificado como controle (o paciente preso com alguma doença que não lhe trouxesse maiores repercussões) certamente foi resultado de resquícios do jeito "científico-natural" de pensar, calcado na relação sujeito-objeto, que atribuo à minha formação médica, a qual não nego mas que neste momento creio ser mais desejoso manter à parte. Proponho-me não a fixar conceitos como ponto de partida ou chegada, comparando formas diferentes de se estar privado de liberdade, mas a pensar a liberdade através e juntamente com as suas distintas privações, acercando-me das singularidades através das quais elas se 
manifestam em cada pessoa que as vive, num caminho aberto do qual no início não podia prever o final.

Enfim, após quatro meses de espera (ativa, com muitos telefonemas e emails) para a aprovação de meu projeto de pesquisa pela Comissão Científica da Santa Casa de São Paulo, passo necessariamente anterior à submissão do projeto à Comissão Nacional de Ética em Pesquisa (CONEP) através da Plataforma Brasil, e outros cinco meses para a aprovação desta, quando depois dos nove meses totais eu finalmente me preparava para entrar com o gravador no CHSP, fui impedida pelo diretor de segurança do hospital, que alegou ser o impedimento de gravação uma norma da Secretaria de Administração Penitenciária do Estado de São Paulo (decisão esta que tardou ainda mais um precioso mês). Tal impedimento foi retirado quando julguei já não haver tempo hábil para a realização e subsequente transcrição das entrevistas, quase um mês ainda após os meses anteriores. Que isto facilite para os próximos pesquisadores que pretendam utilizar ali dentro o gravador...

Com a ideia de gravar as conversas eu pretendia preservar detalhes que anotações e a memória poderiam deixar escapar e tinha o intuito de que o que fosse trazido a esta investigação se mantivesse o mais fiel possível ao que tivesse se passado enquanto eu tentasse, junto dos internos escolhidos, aproximar-me das privações (e) da liberdade. Como a utilização do gravador não me foi inicialmente permitida, e assim a fidelidade aos fatos poderia, segundo o que eu achava, ficar comprometida, optei por abrir mão dela e aproveitar o que esta abertura poderia, então, me possibilitar. Já que não poderei ser fiel às palavras exatas nos relatos dos encontros, poderei ser fiel à passagem destes encontros e sua memória em mim, incluindo-se aí sensações despertadas, interpretações percorridas e o que a própria escrita mais libertada da exatidão dos fatos pode proporcionar, como brechas em que o leitor possa, ele mesmo, levantar voo ou quem sabe olhar para o que de sua própria liberdade ele também esteja privado. Não me preocuparei com precisão de idade, diagnóstico ou prognóstico ou com a objetividade impossível das informações, mas com o que a abertura diante dos encontros me suscitava. Os relatos que trarei a esta investigação contarão também, além do que se conversou em um momento específico sobre a liberdade e suas privações com cada uma das 
pessoas escolhidas, com o que pude recolher observando como elas vivem dentro do hospital penitenciário. Se a pessoa tiver sido atendida por mim em outras ocasiões será inevitável trazer também contextualizações reveladas pelo processo de atendimento, obviamente com o consentimento da pessoa. 0 nome de nenhum dos participantes desta investigação será revelado e os encontros específicos para falar sobre a privação de liberdade somente foram realizados após a assinatura do termo de consentimento livre e esclarecido (em anexo).

A maior dificuldade para levar a cabo a investigação que eu inicialmente pensara foi, entretanto, de outra ordem. Eu achava, quando primeiramente pensei em como fazer esta investigação, que a prisão seria apenas uma das formas de se estar privado do que comumente se determina como liberdade e que, comparando-a com as outras também presentes no CHSP, eu poderia acercar-me do que seria, de fato, a liberdade e sua privação. 0 que eu não suspeitava é que a privação da liberdade na prisão é tanta que me privou também do otimismo através do qual eu me permitia fazer meus questionamentos iniciais, o mesmo otimismo com que eu ousava tentar enxergar possibilidades de liberdade nas vivências de gente reiteradamente privada dela. Privou-me também da ingenuidade com a qual eu cria poder fazer uma pesquisa quase filosófica para pensar acerca do que é a liberdade diante de gente para quem isto está muito longe de ser uma questão e para quem a resposta à minha pergunta, se eu a encontrasse, não faria qualquer diferença. A questão da liberdade foi sendo redimensionada conforme o tempo foi passando e eu continuava trabalhando no CHSP. A esta nova dimensão é que passei a pretender chegar. 
CONTARES

Todas as mágoas são suportáveis quando fazemos dela uma história ou contamos uma história a seu respeito Isak Dinensen, através de Hannah Arendt em A Condição Humana

Apresento a seguir o contar propiciado pelos encontros entre mim e as pessoas que, presas, me confiaram a narrativa de suas histórias. Foram elaborados a partir do que me foi dito em palavras e do que os encontros me suscitaram. Não há uma preocupação com a exatidão das informações como idade, patologia que determinou a internação, tempo de pena ou outros dados de natureza semelhante e sim uma tentativa de fidelidade a outros aspectos. Sentimentos que transpareceram ou que me aconteciam, tonalidades de voz, sutilezas do olhar - possibilitados por uma abertura anterior, decidida por uma afinação específica - me pareceram constituir-se como a ponte que a um só tempo nos unia e separava, como o falar da liberdade de maneira mais verdadeira que a dureza dos fatos - compreendendo aqui verdade como desocultação dos entes (HEIDEGGER, 1995, p.43). A verdade em sua essência manifesta-se como a própria liberdade, através do deixar ser o ente (loc. cit). É esta a pretensão destes relatos: trazer à tona do oculto em que se velava a liberdade de quem está preso. Porque, como nos confirma Antoine de SaintExupéry , "a verdade para um homem é o que faz dele um homem." (2006, p. 132)

Foi propositalmente usado o discurso indireto livre para que me fosse possível trazer o que disseram as pessoas através da minha própria voz. Seria enganoso crer que eu, ou qualquer pessoa, seria capaz de relatar os encontros ocorridos de forma puramente objetiva, sem incluir ao menos traços das impressões e reflexões que causaram. A escolha deste tipo de discurso tenta deixar claro que ocorre tal inclusão. Procurei manter sempre que possível, quando através de minha voz falava a voz daquele a quem escutei, as frases como foram ditas, com as mesmas expressões verbais e às vezes os mesmos lapsos gramaticais, conforme eu as havia anotado no momento do encontro. 
Se houve alguma poesia não foi na maioria das vezes por exigência da situação. A prisão, sua falta de cores no chão cinza, no branco e no bege das roupas, é o desaparecer do poético que ainda assim ousa se insistir. Há fotografias tão belas sem cor e a beleza vem então justamente do acinzentado... Mas nos contares, se houve poesia, foi para por "a linguagem em estado de emergência" (BACHELARD, 2005, p. 11). E porque "tornar imprevisível a palavra não será uma aprendizagem da liberdade?" (loc. cit.) 


\title{
A memória impossível
}

\begin{abstract}
Ainda hoje de manhã, sentindo o cheiro da manhã gelada, pensei que cada um de nós oferece sua vida a uma impossibilidade. (...) É que ao sentir o agonizante arrebatamento de uma manhã que nasce ocorreu-me (...) que a impossibilidade é como se se quisesse atingir o que no entanto seria possível - se ao menos fôssemos outros. E o mais estranho - meditei olhando a enorme folha quieta no chão - é que somos os outros de nós mesmos. Só que - jamais, jamais, jamais.

(...) Este também é o relato de um crime e de desejos antigos. Quanto à realidade, ela pertence à si própria.

Clarice Lispector, "prefácio cortado" de A maçã no escuro, em Cartas perto do coração
\end{abstract}

Eu não me lembro, dizia aquele homem de trinta e poucos anos, tapando para falar o buraco da traqueostomia um pouco abaixo do corte suturado que lhe atravessava o pescoço. Viúvo pelas próprias mãos instantes antes de tentar morrer cortando suas jugulares, tudo o que Breno sabe daqueles momentos que reviraram a sua vida é o que lhe contam, o que leu em seu processo e o que ficou marcado em seu corpo. Devido ao tempo em que esteve em coma, ainda não consegue andar, tem traços de escaras na pele e só fala com a ajuda do polegar no metal que lhe atravessa a traqueia. Fora a dor.

Talvez fosse a única maneira de estar ali. Ainda não caiu a ficha, ele mesmo intuía, explicando que se explicava estar apenas em uma prolongada internação hospitalar toda vez que eu insistia em lhe perguntar se estava mesmo tudo bem. Era difícil crer. Tivera uma profissão estável, morara com o filho mais novo e a esposa e cruzara os dias sem nunca suspeitar que era de sua própria vida que surgiria a maior ameaça a ela mesma - levada a cabo de maneira impensável dentro de quatro paredes que se continuariam numa rotina comum, não fosse uma madrugada em branco em sua memória que exterminara tudo o que ele já havia feito de si.

Seu silêncio me gritava, o calar de sua dor chegava a me chocar. Não havia acesso, e os atendimentos, por meses, eram curtos, rasos, absurdos. 
Um dia, houve um lampejo. Passava na televisão da enfermaria um programa de futebol. Perguntei qual era seu time e em seguida - um papo qualquer - como havia sido vê-lo campeão. Ele inexplicavelmente começou a chorar. E disse que fora na madrugada da comemoração do título que tudo acontecera. Aquilo era como um buraco numa calçada que atravessávamos todos os dias e que nos levava de repente ao outro lado do mundo. Tentei escutar o melhor que a minha surpresa permitiu ali. No próximo atendimento, porém, já não havia na calçada buraco algum.

Cheguei a crer, numa das ridículas profecias de quem tem enorme dificuldade em dar tempo ao tempo que pede, que ele se manteria para sempre naquela dissociação inacreditável com a própria história, escrita tragicamente com as próprias mãos e apagada inevitavelmente da própria memória. Até que um dia ele me acenou do outro lado do mundo - o lado em que talvez eu desde o início estivesse, capaz, só então, de compreender o que quer que fosse daquilo tudo através da dor que ele enfim se deixava ou era capaz de sentir.

Estou mais ou menos, ele me dizia por detrás das lágrimas. A tristeza chegara e com ela seu próprio espanto diante do ocorrido, diante da amnésia, diante dos estilhaços de vida sobre os quais ele há alguns meses se equilibrava. Por que agora?, eu tentava entender. Talvez sua ida a julgamento, ainda que este houvesse sido adiado como recurso do advogado, ele mesmo procurava explicar. Ou talvez a avó. Minha avó é como minha mãe, sempre fui seu preferido, ele contava. Ele recebera há alguns dias, através da visita de uma tia, a notícia de que ela ia muito mal de saúde.

Não foi a primeira vez que me chamou a atenção, ali naquele hospital penitenciário, o terrível da dor de não poder presenciar ou acompanhar a morte de alguém significativo, ou, no outro extremo, o nascer e crescer. Álvaro, um dos primeiros pacientes por mim ali atendidos, esteve internado, pouco mais de um ano antes daquele instante em que eu me encontrava diante da dor de Breno, para o tratamento de um câncer de cujas complicações acabou falecendo. 0 pai de Álvaro também morrera de câncer quando ele já estava preso. Ele falava daquela morte ocorrida havia anos como se o impedimento de ter podido estar perto dos últimos instantes de seu pai e a impossibilidade de ter se despedido fossem as piores consequências de se estar preso. Pareciam muito piores que o cotidiano restrito; 
estar encarcerado, fora do mundo, era mais difícil pelo distanciamento dos grandes acontecimentos das pessoas queridas: seu nascimento e seu desenvolvimento, segundo aparecia no atendimento de homens que haviam sido pais enquanto encarcerados, e sua morte.

Breno, através da dor triste da possibilidade da morte da avó, reencontrara em si o que, calado, já vinha doendo. Como se, ao se deparar com a claridade de uma luz, reconhecesse nela mais que a possibilidade de luzir: algo que em si também já luzia, mas que ele desaprendera a reconhecer. Só que tudo isto ao avesso: não era luz mas a treva que ele reconhecia. 0 nefasto, o trágico tecido com o absurdo no qual se degradara sua própria vida através de suas próprias terríveis mãos. Que ele usava para, na minha frente, tapar o buraco da traqueostomia, fazendo-se ouvir.

Nada, nada justifica o que eu fiz, ele profere depois de contar da traição de que suspeitava estar sendo vítima pela esposa. Pura e terrível dor. Chorava de saudade dos filhos. Estou preso, reconhecia. Ou aprendia pela primeira vez. Estou na cadeia, não no hospital. Eu tinha o sonho de ter uma família, meus dois primeiros filhos não foram planejados, o último, sim. Queria estar com ele e com minha esposa a vida inteira. Nunca imaginei na vida que seria preso.

Antes, eu estava me escondendo da realidade, admite. Fugia do assunto quando perguntavam, dizia que havia sido um acidente quando apontavam para o corte em meu pescoço. Agora, converso mais, falo do que aconteceu. Percebo que algumas pessoas se espantam, principalmente as mulheres. E tem o Edu, ele conta. Conversam muito, riem muito. Será esta conversa, espalhada nos dias, entremeada do silêncio da noite, sempre possível - já que se encontram lado a lado na enfermaria - mas só às vezes escolhida, colhida do cinza daquele chão onde nada se pode plantar, será esta conversa multiplicada à dor da possível morte da avó, o leito onde Breno pode enfim deitar-se para sentir a dor que já lhe doía? Se "o retiro, a separação e o silêncio são suportáveis e fecundos só depois de os havermos muitas vezes partilhado com alguém que, sem afligir-se, esteve contente de prezar conosco um silêncio que não é mudez, apoiando uma separação que não é ruptura e um retiro que não é isolamento" (GONÇALVES FILHO, 2007, p. 190), teria a presença significativa de alguém que lhe pudesse ouvir permitido a Breno transformar a 
opacidade da falta de som, o vazio, em silêncio que pudesse, enfim, fecundar sua dor? Era aquela presença mesmo significativa?

Haveria a possibilidade de alguma presença que fosse significativa em qualquer tempo, passado ou futuro, da história de alguém que foi capaz de matar? Matar alguém significativo; ou seria justamente a significatividade que morrera junto com aquela morte física, crua e absurdamente real?

Embora Breno comparecesse às sessões de fisioterapia para que voltasse a andar pois sua paraplegia não tinha causa irreversível, algo acontecia que impedia sua evolução. Ele é preguiçoso, descreviam os fisioterapeutas; ele fazia os exercícios indicados, mas parecia faltar alguma coisa. Assim como quando ele conversava comigo. Não pela impossibilidade de proferir em voz alta as palavras pela traqueostomia. Era outra coisa que faltava, não a voz. 0 que era aquela falta? A falta de sua própria vida? A falta de perdão? A falta que já havia, sem a qual ele nunca poderia ter matado nenhum ser humano, e que continuava presente, calada, dando apenas indícios de si mesma através de seu não andar e do abafamento de sua voz?

Não há futuro, se o que ele diz esperar ao sair é lutar pela guarda do filho, que está com os avós maternos e que no dia em que perdeu a mãe dormia a poucos metros de tudo. Sente-se rasgado pela saudade do filho, expandida para sua família, impedida de ver o menino pelos avós que o estão cuidando. Sente falta da esposa, admite relutante. Estávamos juntos havia cinco anos, como não vou sentir falta? Jamais pensaria que pudesse fazer uma coisa dessas. Estavam bem, no fatídico dia. Você sente vontade de morrer?, eu lhe pergunto. Hesita. E diz que não, mas não entende porque não morreu quando tentou degolar-se.

0 que ele não entende ainda, eu sem querer penso, é que ele morreu. E que se em algum momento lhe for possível morrer a morte já morrida, ele poderá, então, talvez, talvez, talvez, renascer.

Como você prefere estar, assim triste ou como estava antes de ter "caído a ficha"?, eu pergunto. Depois de pensar, diz que não sabe. E conta, em seguida, uma conversa com a tia. Se fosse sua filha, tia, você iria querer a pena mínima? Iria querer a máxima, né? Estou me preparando para a pena máxima. Eu quero a mínima, mas estou me preparando para a máxima. 
Um dia, ao entrar para atendimento, não encontrei Breno no leito onde passara todos os dias desde sua chegada ao CHSP. Recebeu alvará, doutora, diz Edu, do leito ao lado, com um sorriso de olhos molhados no rosto. Breno conseguira liberdade provisória, apesar do crime pelo qual foi acusado ser homicídio. Talvez por ser dos poucos presos que conta com um advogado particular; talvez porque o laudo da causa da morte de sua esposa concluísse que não foram as seis facadas desferidas contra ela, mas a asfixia pelo vômito que a tivesse matado; talvez porque se encontrasse impossibilitado de andar e de se lembrar do que acontecera. Talvez, para a Justiça, por todas essas causas juntas. ${ }^{21}$

Fico imaginando se, para Breno, alguma dessas causas faria diferença, se todas as faltas continuarão vigentes. Que liberdade era essa que conquistara, provisória no nome? Tempo de voltar à própria vida? Como, se a própria vida como ele a conhecia não existe mais? Se liberdade era fazer o que quiser, como ele me respondeu quando eu lhe perguntara, o fato de não andar, não ter voz, não ter mais sua casa e a proximidade de seu filho, não se configurariam como a ausência definitiva de liberdade? Ou será que justamente o oposto, a liberdade para ter matado a esposa, seria aquele "fazer o que quiser" a que ele se referira? Não me parecia. Ele não se lembrava, e ele não queria. Nós somos os outros de nós mesmos? Sim. Jamais.

No caso de Breno, no entanto: sempre.

\footnotetext{
${ }^{21}$ Durante a redação desta pesquisa aprendi, novamente graças a Marcia Rodrigues Setubal e Tatiana Ramos Malavasi Sales, que o crime de homicídio possibilita liberdade provisória em muitos casos quando a vítima é específica, pois aí não haveria risco social, diferentemente de crimes contra o patrimônio (roubo e latrocínio) cuja vítima pode ser qualquer um.
} 


\section{Como esburacar alguém}

Você estava com uma cara, diziam as minhas colegas que, andando pelo corredor psicossocial, me viram durante o atendimento de Tomás.

Com quase trinta anos, detido desde os dezoito e com poucos anos de pena restantes, ele já planeja os assassinatos que cometerá quando sair. Insultos, cobranças e desentendimentos são considerados por ele motivos justos para que acabe com a vida de quem julgue ser culpado por qualquer sentimento que ele não consiga sentir. E são quase todos. Para ele sentir é como se fosse um tiro de arma que não penetrasse, mas batesse e voltasse na direção de quem o despertou. Contame com tal prazer e detalhamento acerca de seus crimes que é como se considerasse das duas opções, uma: ou que eu tampouco pudesse sentir, ou que ao menos pudesse sentir por ele.

Crente em Deus, tem Jesus no nome e tenta se mostrar como o que acredita ser um homem bom - ou como acredita que eu acredite ser um homem bom. Estudei até a quinta porque precisava trabalhar e ajudar minha mãe a cuidar dos meus três irmãos, ele diz. E segue: aos dezesseis, saí de casa porque não queria trazer perigo para minha família; fui morar com uns amigos numa favela porque minha mãe descobriu que eu estava traficando e tinha matado uma pessoa.

(Considere estes parênteses alguns instantes de um silêncio pétreo e eterno)

Quantas pessoas você matou?, não consegui deixar de perguntar, num determinado momento de nossa conversa, endurecida, sentindo meu coração bater forte e diminuído. Umas seis. Quase orgulhoso diante da minha inominável estupefação. Da minha dor diante dele. Fora os da prisão, né. Aqui você sabe que se mata gente. Eu sei fazer por exemplo faca com a madeira desta mesa, bomba com o oxigênio da inalação...

Está condenado por homicídio e quando estava no regime semi-aberto, "caiu no 57" (ele me informa o número "abreviado" de 157): voltou para regime fechado por assalto. Diz ter assassinado na mesma época um membro do júri popular que crê o haver condenado, mas por isto, não está condenado. Ninguém viu. Eu sinto 
ódio e sou muito vingativo. Você se arrepende? Pelas famílias, sim. Mas eles fizeram por merecer. Antes a mãe deles sofrer que a minha.

Tomás está no seguro por ser de uma facção que não o PCC. É muito pior estar no seguro que estar preso, ele avalia. Lá na unidade, eu fico no convívio (ele está numa unidade prisional em que predomina a facção a que pertence). Aqui, nem sol tem. 0 dia todo trancado, sem distração, sendo tratado como lixo pela enfermagem. Escutando história de gente que estuprou criança. Num é pra dar vontade de matar? (Eu emudeço). Mas eu ajudo! Eu dou água, ajudo até essa pessoa que fez essa coisa horrível. (Eu também. E encolho.)

Tomás está internado por uma infecção que lhe acometeu a medula e que o está impedindo de andar, ainda não se sabe se provisória ou definitivamente. 0 que me revolve me joga pensamentos vingativos: que não ande nunca mais, minha raiva diz. Mas eu lhe pergunto, engolindo seco, se está dormindo bem à noite e como se sente com o fato de precisar da cadeira de rodas. Pergunta que salta, com um esforço terrível, o buraco que o homem na minha frente cavou em mim. Eu já fui um ser humano, mas hoje não sou mais. Ele diz.

Não tive pai, e cresci na favela. Quantas pessoas não tiveram pai e cresceram na favela e não matam, Tomás? (eu inutilmente pergunto). Eu me sinto mal quando faço o mal, mas sou tomado pela fúria. Se você vai esperar sair daqui para fazer o mal, é fúria? Você não acha que pode haver outros jeitos de resolver as coisas? (eu inutilmente pergunto). Ele rebate me perguntando se eu não acho que o que tal pessoa lhe fez fere sua honra a ponto dele ter que matar. Não. Não. Não. Não. (eu inutilmente respondo). "A fúria de um detento oprimido é bem pior que a de um louco". Ele diz. E as palavras ali parecem se fazer passíveis de bater e voltar assim como os sentimentos que ele não é capaz de abrigar. Tudo o que ele diz me parece oco. Falta sempre o outro - naquele momento, eu, esburacada pelos tiros todos de sentimentos impedidos, de palavras esvaziadas esvoaçando perdidas, e pelos que de fato existiram.

Ao longo dos atendimentos, Tomás diz que vai "criando confiança" em mim, ainda que quem me veja do corredor note a mesma cara do primeiro. Fala com raiva da psicóloga que, acertadamente, não viu demanda para seus atendimentos. Eu 
precisava desabafar com ela. Quando eu pego ódio, é ódio, mas quando eu confio, eu confio. Ele me pede que coloque seu nome verdadeiro no trabalho que explico que farei quando lhe peço que assine o termo de consentimento. Diz que colocará também o meu no livro que vai escrever, e que vai se chamar "Minha vida, vida minha" - a primeira significando a que sobreviveu depois de tudo o que ele passou, e a segunda, a que cada um tem, ele me explica.

Do outro lado da mesa, eu sinto uma vontade enorme de sair correndo, de encerrar os atendimentos também, de aliás ir embora dali e nunca mais voltar, de chorar a dor que não existe. Sinto medo - o que, tirando o que me acometeu em meus primeiros dias de trabalho no CHSP, aconteceu poucas vezes.

O que é liberdade, Tomás? É o livre arbítrio de fazer o que você quiser, ele responde. Se você faz o mal, colhe o mal. Se faz o bem, colhe o bem. Deus vai colocar na balança se o resultado final do que eu fiz é bom ou mal.

E a prisão? 0 que você acha da prisão? Na prisão eu aprendi a ter paciência para esperar a hora certa de fazer as coisas. Um assalto tem que ter um momento certo. E a vingança, como é aquele ditado? (fico quieta.) A vingança se come fria.

Ao sair, ele se desculpa por alguma coisa.

Algum tempo depois, Tomás recebeu alta do CHSP, ainda na cadeira de rodas, mas conseguindo dar alguns passos com andador. Aguarda, na penitenciária onde não precisa estar no seguro, que finde o tempo de sua sentença. 0 que não tardará. 


\section{Um homem}

Ele definhava: a cada vez que eu o via, encontrava menos carne por detrás daquela pele que começava a colar nos ossos. Parecia que tudo o que se passava em Damião ia também se aproximando da superfície. As palavras iam se tornando poucas, reduzindo-se ao essencial; as lágrimas jorravam como se fossem os poros quem chorasse, ele todo feito tristeza.

Há vinte anos dos seus cinquenta e poucos preso e há vinte anos no seguro, ele nem se queixa mais de passar o dia inteiro trancado num recinto sem janela, sem televisão, sem céu nenhum para ver a cor, sem sopro algum de vento. A única coisa que o distrai das quatro paredes a que seu agora diminuto corpo se encontra restrito é uma bíblia emprestada. E a lembrança. Livre é a mente, ele dizia quando ainda sobravam palavras. A gente voa, vai pra qualquer lugar e volta pro lugar que estou e pra tudo aquilo que aconteceu, continua. Cinquenta e poucos anos: sua idade não coincide com o documento. Não havia cartório na cidade em que nascera, e foi registrado somente alguns anos depois.

Sempre fui trabalhador: ajudava meu avô na roça desde pequeno, depois virei ajudante geral e mais depois motorista. Eu gostava de dirigir, ir em feiras de artesanato nos domingos. Agora, fico remoendo, relembrando, pensando em tudo aquilo. Como é ficar tanto tempo sem sair da prisão?, eu pergunto. A gente consegue enfrentar esses obstáculos. A maioria das dificuldades, é como se a gente estivesse lá fora, mas isso é difícil de explicar. Não é só a doença, mas é a vida real.

Acusado e sentenciado por estupro e homicídio, diz que, arrependimento, sente de tudo. Fiz mal pra mim mesmo muitas coisas. Já tirei vida, prejudiquei a vida dos outros... 0 mal é a gente mesmo que trás pra gente. 0 sofrimento faz a gente se arrepender. Não só a doença, mas tudo. A prisão, a doença.

Conta de sua vida fatos nunca confirmados. Diz ter uma filha que fez psicologia e uma tia em seus últimos dias, intubada numa UTI. Ela exige cuidados de alguns familiares que por isso não o têm podido visitar. Fala de parentes que a assistente social nunca conseguiu localizar. Sofre ao lembrar do acidente que diz haver matado onze membros de sua família quando iam visita-lo na penitenciária 
em que estava detido. Ainda que não me seja possível acreditar que um tal número de pessoas possa entrar na prisão em uma única visita, preciso compreender que aquela tragédia lhe é mais suportável que a completa falta de visitas se os seus estivessem vivos.

Queixa-se somente de dividir, durante o dia, o recinto com muitos outros detentos que vêm para consulta ambulatorial e que têm chance considerável de ter tuberculose. Ele, mesmo com a vida há tanto tempo confinada a poucos metros quadrados e com a perspectiva de, com sorte, ali permanecer pelos próximos dez anos, tem pavor de morrer. Em uma única ocasião me disse que gostaria que Deus o levasse. Era muito sofrimento. Sim.

Descobriu há poucas semanas que tem câncer, ele que já há anos estava habituado com os remédios todos da AIDS contraída e descoberta na prisão. Mas tem muito, muito medo da quimioterapia. Não é de ouvir falar: eu já vi gente passar pelo mesmo processo e não aguentar, ele explica. Peço a Deus que me dê força pra sair pra rua, para ver a liberdade.

E pede a mim que tente alguma maneira para que ele possa ver o filho, de vinte e cinco anos, também preso, por atentado violento ao pudor. A única chance de que isso aconteça é o filho adoecer e precisar de atendimento no hospital ${ }^{22}$. 0 que poderia ser considerado, ainda que torto, um milagre.

Para esgarçar seu medo e tornar a espera pela quimioterapia ainda mais insuportável, o início do temido tratamento atrasou. Não pôde ir fazer os exames de estadiamento do tumor, realizados em outro hospital, porque no dia agendado não havia escolta. Isso acontece muitas vezes no CHSP. Como se Damião pudesse oferecer, todo fraqueza, algum perigo ou risco de fuga para precisar de escolta. Tomografias marcadas, consultas há semanas esperadas, cirurgias por serem realizadas podem tardar muito mais a acontecer porque no dia há muito aguardado simplesmente não há viaturas policiais para escoltar, mesmo que os responsáveis por isso saibam dos agendamentos com antecedência. No caso de Damião, os dias de

\footnotetext{
22 Outra valiosa informação cedida por Marcia Rodrigues Setubal diz que há previsão legal para este tipo de visita quando o caso é de enterro ou doença grave, bastaria que o diretor da unidade onde está o filho autorizasse e a escolta o quisesse trazer.
} 
atraso significam que seu tumor se expande, que sua dor aumenta, e que ele inteiro diminui. Assim como sua chance de ver a liberdade.

A liberdade é um dia poder sair, reconstruir minha vida e poder tocar o barco para a frente. Dentro da prisão a gente é livre, mas não totalmente. Porque a gente é limitado. É livre como? A gente é livre até certo ponto: eu posso vir aqui conversar com a senhora, ou com a psicóloga, ou com os outros presos. Então a parte que você é livre é quando conversa com as outras pessoas? Isso, ele responde, com ênfase. Mas com os presos, a gente não pode conversar tudo. Tem certas coisas que não fica bem conversar com os companheiros.

Estou adaptado, porque não tem outra coisa, a não ser aquela rotina, ele me fala. Sua nova doença arrancou-o do que havia logrado constituir como hábito, por mais insuportável que sua vida me parecesse. Era a sua. Com o tempo, tem cada vez mais dificuldade de andar. Eu recaí, ele diz, descrevendo suas quedas no chão. Seu quadrado vai ficando demasiado grande para o que seu corpo aguenta caminhar. Cada passo se torna lento, tornando aquele tempo que já não passava expandido à eternidade. E mesmo mal capaz de andar, tem que manter a cabeça baixa e os braços para trás.

Lembro-me, enquanto me esforço em tardar o passo para que ele me acompanhe até a sala de atendimento do ambulatório, do que no encontro anterior ele havia me dito e que já agora lhe é impossível de dizer. 0 mais difícil na prisão é quando alguém está saindo em liberdade. A gente olha: poderia ser eu. Ao mesmo tempo estivesse livre, ao mesmo tempo estivesse preso.

Agora seria impossível que ele proferisse uma frase tão longa. Uma vida cujas camadas fossem se retirando e ficasse um caroço de gente. Sua história, os crimes pelos quais foi condenado, a distância da família. Olho para sua magreza espantada, olho para o homem sentado diante de mim, para as lágrimas que jorram. Ele agradece muito o atendimento - alguém que lhe tire daquele todo dia todo e diante de quem as lágrimas possam jorrar. Eu ardo em impotência. Se ao menos o filho...

Da liberdade? Sonhei que acordei e a porta estava aberta. Corri e ela estava fechada. Bati na grade. 
Antes que eu terminasse de escrever estas palavras, Damião faleceu. Sem receber a visita do filho preso, liberada pela segurança do CHSP e da penitenciária em que ele estava. 0 filho. Que existia. 


\section{Quando se insiste em nascer}

Ela tinha um nome estranho porque vinha de longe. Se todas estranhavam aquele nome tão diferente, Bixima sentia o mesmo diante do nome de cada Maria, Viviane, Priscila, Natalia que de repente passaram a estar ao seu redor; em sua terra aquelas sonoridades não existiam em todos os lugares, apesar de que em Angola, seu país, se fala, além das línguas das etnias, o português.

Não só os nomes e a língua eram diferentes. A comida, o clima, a que Bixima tinha acesso apenas pelo céu quadrado do pátio, as leis. Da cidade, ela não poderia dizer nada, porque foi presa chegando ao aeroporto de Guarulhos por tráfico internacional de drogas e não chegou a conhecê-la. Era a primeira vez que ela se decidira a tentar ganhar dinheiro daquela forma, apesar de que há muito tempo o dinheiro lhe fazia falta. Era a primeira vez que saíra de Angola. Morava com quem era seu companheiro havia quinze anos e com a filha de treze num lugar que a imaginação dificilmente alcança. Não havia quase nada em sua casa. Não havia telefone e nenhuma maneira de comunicar a eles (através do Consulado de Angola) que ela estava viva e, se voltar, irá demorar.

Logo que foi presa descobriu, através dos exames a que teve que se submeter, que estava bem no início de uma gravidez. Uma notícia surpreendente e naquele momento triste, porque não havia ninguém com quem a poderia compartilhar. Era como um segredo compulsório e invertido: os seus de nada saberiam, enquanto as pessoas estranhas que passaram repentinamente a compor seu cotidiano tão restrito viam crescer sua barriga desconhecida. Era também como se crescesse em seu ventre o que a poderia ligar com sua terra, com sua família: o filho de seu companheiro, irmão de sua filha, concebido quando se despedia de sua vida para rumar, sem saber, à vida a que agora se restringia. Pouco espaço, pouca cor, pouco jeito de tornar cada dia diferente do outro - a vida que lhe cabia viver numa penitenciária feminina do sistema carcerário brasileiro, onde nada do que lhe rodeava poderia lhe remeter a si mesma.

Não foi pelo tempo previsto que os estranhos presenciaram o crescer de sua barriga. Sete meses após ser concebido nasceu o filho de Bixima, frágil, tão frágil, 
que por alguns meses esteve sempre quase prestes a morrer. Neste tempo, necessitou cuidados hospitalares constantes, dos quais sua mãe não pode participar: ela não podia sair da penitenciária em que estava, e precisou enfrentar ainda esta separação sobreposta à que já lhe doía. Bixima viveu por três meses a dor dentro da dor, que transparecia na sua cara fechada, nos seus músculos retesados, na comida que não lhe entrava e no falar que não lhe saía. 0 corpo de Bixima diminuiu.

Até que seu filho vingou e pode deixar o hospital em que passou os primeiros tempos de sua vida - tempos sem absolutamente nada que pudesse remeter à sua origem, sem ninguém que o olhasse com o carinho do familiar ou lhe falasse com a voz do que poderia se configurar como o conhecido. Tempos em que Bixima se reduzia à dor seca de se ver destinada ao deserto do desterro, feita de tristeza apenas.

Quando Bixima e seu filho chegaram ao CHSP para o chamado trânsito amamentação, ainda que o leite dela já houvesse secado por falta de quem o tomasse, ambos estavam no que poderia se chamar de estado bruto de destruição. Ou nem isso: o bebê, com sua atonia muscular e sua falta de vigor, era como se nem tivesse se constituído para ter o que destruir. Nascido prematuro extremo, tinha que mamar em pé porque aspirava o leite e estava, segundo avaliação de todos os profissionais que o acompanhavam, com grande déficit cognitivo-motor. A esperança era pouca, pensava a equipe de saúde que começara a os acompanhar. Uma história triste com um fim equivalente, esperavam todos.

Mas o encontro entre Bixima e seu filho foi feliz, no meio da história triste. Ela falava e cantava para ele na língua de sua avó, abraçava e cuidava, fazia sons estranhíssimos dos quais ele parecia gostar muito. Pouco a pouco a moleza dos músculos dele foi endurecendo em tônus, enquanto o retesado dos músculos dela se dissolvia enquanto carinho que ela confiava a ele. Grama a grama, ambos ganhavam peso; olhar a olhar, eles iam construindo um mundo que pudesse lhes caber, um oásis de pertencimento mútuo em meio àquela terra sem terra, limitada e tantas vezes estrangeira.

Ganhavam força, ambos, a partir de seu encontro. Bixima lavava roupa de seu filho e dos filhos das outras mulheres para ganhar a roupa dele, porque ela 
obviamente não recebia visita para trazer o que precisasse para o vestir. E começou a entender e falar a língua que ia deixando de ser tão profundamente estranha.

Assim como seu bebê, que arregalava os olhos agora ávidos por ver ao redor, Bixima sorria. Mas não se podia comunicar com os de sua família, e era acometida por uma grande dor culpada: sua filha devia achar, de Angola, que ela a abandonara. Chorava a culpa. Repetia a si mesma e a quem lhe perguntasse que não era bandida. Fizera algo errado porque precisara. Nunca havia sido presa antes, e não seria de novo.

Uma rotina se fazia: cuidar do filho, cuidar da cela, lavar muita roupa para conseguir cuidar do filho, ficar triste, ficar cansada. Tudo é difícil, ela dizia; nada vem simples, para conseguir qualquer coisa eu preciso fazer outra. Mas difícil mesmo ficava tudo quando seu filho adoecia e precisava ser levado ao hospital. Ela se transformava, a cara se fechava, de novo endurecida, pouquíssimas palavras. Foi num momento destes que conversei com Bixima a primeira vez. Estou cansada, já falei tudo isso muitas vezes, e fechava a cara. Assim permanecia até a volta de seu bebê, quando de novo voltava a olhar nos olhos das pessoas. Da próxima vez que conversamos, estava tranquila, arrumada, sorridente, e podia falar. A vida é difícil, a vida das pessoas é difícil quando você não está trabalhando. A família toda estava sofrendo. Ela não tinha ido à escola, mas escrevia um pouco na língua de sua avó, que falava além do francês e um português muito diferente. Aqui tudo é difícil. Faz muito frio. Ter filho na cadeia, não consegue nada. Uma pessoa normal não pode viver na cadeia. Eu tenho força para lutar, para bater até sair sangue. Aqui não, porque senão dão bonde.

As pessoas gostavam dela e de seu filho, que era carinhosamente chamado por uma ASP de Bombom. Toda a equipe de saúde conhecia e se sensibilizava com sua história, com sua força, e com a beleza e a esperteza de seu menino, e gostava também de ouvir aqueles sons tão estranhos de carinho que ela lhe fazia.

Mas para Bixima, tudo é difícil. Estar presa e estar longe de casa. Você pode passar fome, mas tem liberdade. É pior estar presa do que passar fome. Liberdade é a vida da pessoa. Liberdade, né? 
Tenho muito medo de perder meu filho para o abrigo. Se eu perder meu filho, minha vida acaba. Tudo é difícil. Tenho bom convívio no pavilhão, mas ninguém é amigo. Não tem família, tem pensamento, não tem notícia. Eu abandonei minha filha. Eu a olho enquanto ela vira o rosto para o lado e silencia.

Houve um momento em que ela começou a achar que estava doente. Tenho HIV. Mesmo que o exame de sangue que já fizera apontasse que não. Ela pediu que fosse realizado outro. Veio negativo, Bixima. Ela insistia. Eu sei, eu sinto. Já me disseram que eu tenho. Eu tenho HIV, me dê remédio. Não havia como a convencer de que ela não estivesse doente. Não havia como a convencer de que não havia remédio. Não há remédio se não há doença. Ou se o mal que a acomete é a culpa. Não, Bixima. Não há remédio para esta sua história.

Onde não havia casa, ela construiu uma, lavando roupa e através da estranheza de seus sons. Quando a casa se fez por sobre o terreno do impossível, a culpa ainda não cabia ali dentro e talvez, se tomasse emprestado um nome de doença, Bixima teria o que fazer com ela. Era uma casa tão frágil que beirava a inexistência e que na verdade só se podia ver com grande esforço e que, além disso, estava a cada instante ameaçada de ruir.

O filho de Bixima já passara há meses dos seis meses, idade da terrível "entrega": momento em que os bebês do trânsito amamentação devem sair dos cuidados de suas mães para passar aos cuidados de algum familiar que se ofereça ou, na falta dele, de um abrigo. A última opção seria a mais próxima para o filho de Bixima, porque não havia familiar algum. Mas assim como toda a equipe do hospital se sensibilizou com a história de Bixima e seu filho, também se sensibilizou a defensora pública encarregada de sua defesa. E ela conseguiu, contrariando todas as probabilidades em se tratando o crime cometido aqui de crime classificado como hediondo (por mais absurdo que tal qualificação, dentro deste contexto, possa parecer), que Bixima fosse autorizada a cumprir sua pena em prisão domiciliar. Isto porque, com necessidade de cuidados tão especiais para que continuasse se desenvolvendo ou mesmo para que não morresse, possivelmente ele não sobreviveria a um abrigamento. (Tampouco Bixima sobreviveria ao abrigamento de seu filho, mas por outro motivo.) 
Chegou, então, o dia em que, através da despedida, pareceu que a estada de Bixima e seu filho no CHSP houvesse sido até boa. Ela chorava, abraçava, era abraçada - pela sua saída, e pela casa que havia construído a despeito de tudo que lhe dizia não ou não lhe dizia nada. Emocionou-se ao me dar tchau, esquecida da doença que afirmava ter, carregando o lindo filho nos braços, que sorria, sem suspeitar que as cores que até então havia visto eram em número infinitamente inferior às que existiam no mundo.

A última notícia que soube de Bixima foi a de que estava cumprindo sua prisão domiciliar na cidade de São Paulo. 


\section{A LIBERDADE}

Peço licença ao leitor e aos meus interlocutores que me contaram um pouco de sua história para falar algo sobre a liberdade, não sob o ponto de vista de quem vive sua concreta privação na prisão, mas sob o de quem se pôs a pensar acerca dela. Com isso, pretendo como que acender um fogo baixo que possa, mais adiante, ajudar-me a "cozinhar" a discussão sobre o que é a liberdade para essas pessoas de quem tentei chegar perto. Além da licença, peço perdão se as palavras que se seguem voarem abstratas demais, sem guardar relação com as grades atrás das quais até agora (não) estivemos. Espero, mais à frente, conseguir remediar, se for preciso, a abstração.

A liberdade está presente na vida do homem cotidianamente, seja porque de um jeito ou de outro a experimentamos, seja porque de alguma forma sempre a compreendemos. A maneira como empregamos o vocábulo nos revela algo desta compreensão e ele está em toda parte: nas nossas conversas, nos sonhos, no modo como enxergamos nossas limitações, no que planejamos para nossas vidas, nos nossos relacionamentos. Se perguntarmos para as pessoas o que é liberdade a resposta será provavelmente parecida: quem está falando, nesta semelhança de respostas que a maioria das pessoas daria, é o que se chama senso comum. Muitas das respostas que escutei dos presos para quem perguntei sobre liberdade também pareciam vir mais do senso comum que da vivência do que eles experimentavam como a liberdade e sua privação (voltarei a falar disso adiante). 0 compreender do senso comum não é equivocado, mas pode ser incompleto e se mostrar algo desafinado se nos detivermos mais a pensar acerca dele.

Nossa compreensão cotidiana com muita frequência relaciona liberdade com poder: ser livre é poder fazer o que se quer. Na prisão, o fazer o que se quer aparece bastante como poder ir para onde se quiser, pois o ir e vir é o mais imediatamente limitado, embora não o único. Tanto para poder fazer quanto para poder transitar, a liberdade passaria a se relacionar com ter recursos distintos (financeiros, cognitivos, emocionais, condicionais, etc.) que permitissem aqueles poderes - e assim a liberdade seria algo que se poderia ter, atingir definitivamente, colocar 
como objetivo ou alcançar. Na verdade, um chegar à liberdade de tal forma nunca ocorre, e não porque nunca se atinja o objetivo, mas porque “(...) a liberdade não pode ser guardada. Na verdade, o ser livre (...) só se consuma quando se consome. É destruindo a liberdade, a cada vez, a cada escolha, que nós exercemos o ser livre." (POMPEIA e SAPIENZA, 2011, p. 23) Também relacionamos costumeiramente liberdade com ausência de restrição - que é outra concepção implícita de privação de liberdade no contexto do aprisionamento. Se compreendemos, no entanto, liberdade como abertura, nunca se está completamente privado de liberdade, porque "a condição humana de liberdade como abertura nunca é eliminada, ainda que possa se revelar muito encolhida(...)” (FREITAS, 2011, p. 64), como no caso de se estar encarcerado. Costumamos compreender também a liberdade como ausência de vínculos ou de rumo: não estar vinculado a ninguém ou não estar no curso de um projeto nos dá cotidianamente a sensação de ser livres pela ausência de uma determinação prévia. 0 que se passa, porém, como nos esclarecem Pompeia e Sapienza, é que "ser livre "de" qualquer determinação é (...) ser livre "para" a determinação, ser livre para o compromisso." (2011, p. 23); comprometer-se, em cada situação, com vínculos ou projetos, não é "abrir mão" da liberdade, mas o contrário, porque, quando autenticamente compromissado, “o compromisso não é o oposto ao ser livre, é a sua realização" (loc. cit.).

Da falta de vínculos que poderia significar liberdade, Saint-Exupéry nos conta em Terra dos Homens a história de Bark, um servo recém liberto que é deixado com dinheiro numa terra estranha, com pessoas estranhas:

(...)todos respeitavam nele um homem livre, (...) mas nenhum havia mostrado tampouco que tivesse necessidade dele. Era livre, mas infinitamente livre, a ponto de não sentir seu peso sobre a terra. Faltava-lhe o peso das relações humanas que entrava a marcha do homem, e as lágrimas, e os adeuses, e as lamentações, e as alegrias, tudo o que um homem acaricia ou ofende sempre que esboça um gesto: esses mil laços que o prendem aos outros, que lhe dão gravidade. (2006, p. 86)

Ser "infinitamente livre" retiraria da liberdade um lastro que lhe é essencial, tão constituinte quanto as possibilidades nas quais o ser livre se abre a cada vez. A liberdade precisa ancorar-se na contingência da vida de cada um, senão tampouco 
existe (como se verá adiante). É muito diferente daquele "poder fazer qualquer coisa" que estamos acostumados a lhe atribuir - pode ser até seu oposto. Bark, recém liberto, com dinheiro para fazer o que lhe aprouvesse, percebeu que se distanciava de si mesmo e então da liberdade. Gastou todo o dinheiro ganho em presentes inúteis para as crianças da cidade em que fora lançado e na qual parecia pairar e foi só o retorno à condição de miséria que o devolveu a si mesmo antes de voltar à sua casa:

(...) Bark avançava, banhado por aquele mar de crianças, como outrora entre suas ovelhas, abrindo seu primeiro sulco no mundo. Regressaria, no dia seguinte, à miséria dos seus, responsável por tantas vidas que seu velho braço talvez já nem pudesse sustentar. Mas ali já pesava seu verdadeiro peso. (op. cit., p. 87)

A miséria de Bark poderia ser interpretada como a possibilidade da liberdade ainda num outro sentido, o da indigência, do "não ter nada a perder" e por isso ser livre. No caso de Bark, não se trata disso, mas de voltar a ser quem ele é.

Proponho agora que nos detenhamos um pouco mais no pensamento acerca da liberdade para Hannah Arendt.

\section{HANNAH ARENDT E A LIBERDADE}

Perguntando-se o que é liberdade, Hannah Arendt de antemão coloca a dificuldade de tamanha tarefa. Pensar a liberdade significa mirar para o que não parece ter lógica e talvez isso seja porque aproximar-se de seus significados é aproximar-se de algo crucial para o homem, que no entanto não é passível de ser resolvido numa objetivação petrificante. 0 significado da liberdade para o homem e na vida do homem escapa-lhe ao ser alcançado, assim como a própria liberdade, já que o agente (o homem que age e pode, assim, ser livre) "parece perder sua liberdade no exato momento em que lança mão dela" (ARENDT, 2007, p. 246). A complexidade de se pensar o que é a liberdade se inicia na contradição entre a nossa suposta responsabilidade por cada comportamento, gesto ou ato, guiada por nossos 
princípios morais e consciência, e o fato de que, cotidianamente, parecemos agir segundo causas internas ou externas a nós mesmos. Continua no fato de que a questão da liberdade foi deslocada ${ }^{23}$ de seu âmbito primordial, o político - âmbito que é o encontro entre os homens, plurais - para outro em que se torna, em si, estranha, o da vontade, interior e impositiva por definição, pois "deve parecer realmente estranho que a faculdade da vontade, cuja atividade essencial consiste em impor e mandar, seja quem deva abrigar a liberdade" (ARENDT, 2011, p. 190). Arendt insiste que, apesar da ocorrência de tal deslocamento, nunca se deve ignorar que a imbricação entre política, ação e liberdade é tamanha que uma é inconcebível sem as outras duas.

A liberdade imbricada à política é oposta ao que conhecemos como "liberdade interior", que surge, na verdade, quando se faz necessário retirar-se de um mundo em que, por estranho, a liberdade foi negada, para um refúgio interior. Neste refúgio, desconexo de mundo, poderia se exercer no e através do isolamento uma suposta liberdade absoluta, que é, no entanto, a completa ausência dela em sentido político. 0 conceito de liberdade interior teve grande influência sobre a tradição do pensamento, embora ele seja sempre derivado de uma experiência de liberdade primordial que só se dá com os outros, nunca consigo mesmo. Este "com os outros" não significa a mera convivência, que pode servir simplesmente para dar conta das necessidades e da preservação da vida, mas a constituição de um organismo político, numa esfera pública que possa ser palco para a ação e o discurso. "Sem um âmbito público politicamente assegurado, falta à liberdade o espaço concreto onde aparecer." (op. cit. p. 195) Liberdade tampouco pode ser meramente identificada com livre arbítrio que, se o pensamento é um diálogo interior, poderia ser descrito como "um conflito dentro de mim mesmo, no antagonismo interior entre o que quereria fazer e o que faço" (op. cit. p. 204).

A liberdade, política, é o que inaugura algo que antes não existia. A ação livre "deve ser livre, por um lado, de motivos, e por outro, do fim intencionado como um

\footnotetext{
23 Não cabe aqui detalhar as circunstâncias do importante deslocamento da liberdade do âmbito politico para a vontade interior. Para tanto, consultar "O que é liberdade", in Entre o passado e o futuro, de Hannah Arendt.
} 
efeito previsível" (op. cit. p. 198), o que não diz que não deva haver motivos e objetivos, mas que eles, embora determinantes, são ultrapassados pela liberdade da ação. Identificar um objetivo através do intelecto, coloca Arendt, não é uma questão de liberdade mas de julgamento, e a vontade, que tem "o poder de comandar, de ditar a ação, não é uma questão de liberdade, mas de força ou fraqueza" (loc. cit.).

A liberdade brota de princípios. Princípio é algo inexaurível (pode repetir-se) e universal (não está ligado especificamente e nenhuma pessoa ou grupo), e diferente do "juízo do intelecto que precede a ação e do império da vontade que a inicia" (op. cit. p. 199), que se esgotam ao longo da ação, atualiza-se durante, e somente durante, seu transcorrer. Princípios, exemplifica Arendt, são a honra, o amor à igualdade, a distinção, a excelência, mas também o medo, a desconfiança, o ódio. Ela segue:

A liberdade ou o seu contrário surgem no mundo sempre que tais princípios são atualizados; o surgimento da liberdade, assim como a manifestação de princípios, coincide sempre com o ato em realização. Os homens são livres - diferentemente de possuírem o dom da liberdade - enquanto agem, nem antes, nem depois; pois ser livre e agir são uma mesma coisa. (loc. cit.)

Agir exige coragem, que é a superação das necessidades vitais individuais abrindo o mundo como palco onde o homem pode ser si mesmo diante de e com os outros. Quanto à coragem, Arendt fala:

É preciso coragem até mesmo para deixar a segurança protetora de nossas quatro paredes e adentrar o âmbito político, não devido aos perigos específicos que possam estar à nossa espreita, mas por termos chegado a um domínio onde a preocupação para com a vida perdeu sua validade. A coragem libera os homens de sua preocupação com a vida para a liberdade do mundo. A coragem é indispensável porque, em política, não a vida, mas sim o mundo está em jogo. (op. cit., p. 203)

Muito comumente, desde que a tradição de pensamento cristã se instaurou, identifica-se liberdade com o poder fazer o que pede a própria vontade, com o livrearbítrio. Mas a vontade, se solitária, divide-se no diálogo que sempre, quando só, uma pessoa tem consigo mesma e isto a paralisa e encerra dentro de si mesma (diferente do que acontece com o pensamento, pois pensar é dar ouvidos ao diálogo 
que se estabelece entre si e si mesmo). “O querer solitário é sempre (...) querer e não querer ao mesmo tempo" (op. cit. p. 206), pois seria uma "monstruosidade" a vontade, cuja essência consiste em mandar e ser obedecida, ordenar ao homem que mande a si mesmo, sem que seja obedecido. A própria manifestação original da vontade se dá quando ela não pode se exercer, através da experiência de querer e não poder. Tal impossibilidade pode advir da necessidade, como nos esclarece Arendt:

\footnotetext{
A necessidade que me impede de fazer o que sei e quero pode surgir do mundo, ou de meu próprio corpo, ou de uma insuficiência de talentos, dons e qualidades de que o homem é dotado por nascimento e sobre os quais ele tem tanto poder quanto sobre as demais circunstâncias; todos esses fatores, sem exclusão dos psicológicos, condicionam exteriormente o indivíduo no que diz respeito ao quero e ao sei, isto é, ao próprio ego; o poder que faz face a essas circunstâncias, que liberta, por assim dizer, o querer e o conhecer de sua sujeição à necessidade, é o posso. Somente quando o quero e o posso coincidem a liberdade se consuma. (op. cit. p. 208)
}

A liberdade de que ela fala na citação acima, é bom que se esclareça, é a que é comumente entendida como querer e poder, e que, por um lado, condiciona a política, mas não a abrange completamente. Por ter o caráter de trazer à existência o que não havia a liberdade (política) ultrapassa a vontade, embora possa ser, apenas inicialmente, condicionada por ela. A discussão acerca da vontade, então, desde que a liberdade foi deslocada para o interior do homem, atravessa o questionamento acerca da liberdade. Mas a vontade, cindida dentro do si mesmo, não pode ser determinante da liberdade; "os homens descobriram pela primeira vez a vontade ao vivenciar sua impotência, e não seu poder." (op. cit., p. 209), pois a vontade que se realizasse instantaneamente nem chegaria a se configurar como vontade, mas como realização. "Se o homem tem uma vontade, parece sempre como se houvesse duas vontades presentes no mesmo homem, lutando pelo poder sobre sua mente. Portanto, a vontade é poderosa e é impotente, é livre e não é livre." (loc. cit.) Não pode, então, gerar um poder genuíno e, no conflito interior ao "eu", é sempre derrotada. "É como se o eu-quero imediatamente paralisasse o eu-posso; como se, no momento em que os homens quisessem a liberdade, eles perdessem a capacidade de ser livres." (op. cit. p. 210) Uma vontade de poder fadada à derrocada se torna 
imediatamente vontade de opressão, e é este o motivo pelo qual equacionamos poder com opressão, com todos os perigos que isso traz. 0 desvio filosófico da liberdade da ação para a vontade fez com que seu ideal deixasse de ser o virtuosismo, ou "a excelência com que o homem responde às oportunidades que o mundo abre ante ele à guisa de fortuna" (op. cit. p. 199), para se tornar "a soberania, o ideal de um livre arbítrio, independente dos outros e eventualmente prevalecendo sobre eles" (op. cit. p. 211). O equacionamento da liberdade com a soberania, no entanto, se a liberdade de um homem ou grupo só se dá às custas da de todos os outros (ou seja, de sua soberania), e ao se perceber que a soberania nunca será, façase o que for, alcançada, leva à negação da liberdade humana:

Sob condições humanas, que são determinadas pelo fato de que não é o homem, mas são os homens que vivem sobre a terra, liberdade e soberania conservam tão pouca identidade que nem mesmo podem existir simultaneamente. Onde os homens aspiram a ser soberanos, como indivíduos ou como grupos organizados, devem se submeter à opressão da vontade, seja esta a vontade individual com a qual obrigo a mim mesmo, seja a "vontade geral" de um grupo organizado. Se os homens desejam ser livres, é precisamente à soberania que devem renunciar. (op. cit. p. 213)

Se a maneira como pressupomos a liberdade nos dias de hoje nos conduz a concepções tão perniciosas, é necessário pensa-la como foi originariamente vivida. A antiguidade, nas experiências grega e romana, nos legou, através das palavras com que denominavam a ação, a concepção de que ser livre e iniciar algo novo, agindo, são o mesmo. Liberdade e agir são a mesma coisa através do começo, que se reinaugura em cada homem:

No nascimento de cada homem esse começo inicial é reafirmado, pois em cada caso vem a um mundo já existente alguma coisa nova que continuará a existir depois da morte de cada indivíduo. Porque é um começo, o homem pode começar; ser humano e ser livre são uma única e mesma coisa. Deus criou o homem para introduzir no mundo a faculdade de começar: a liberdade. (op. cit. p. 216)

O caráter humano do homem consiste na liberdade de iniciar algo novo numa vida cercada e mantida por automatismos. Os processos naturais, terrestres ou cósmicos, a satisfação das próprias necessidades, a manutenção da espécie e até mesmo os processos históricos, embora acionados pelo homem, são automáticos e 
conduziriam o homem à ruína que lhe é biologicamente inerente, se não fosse a capacidade humana de agir através da liberdade que, mesmo como faculdade, está sempre presente no homem enquanto homem.

O homem enquanto homem é um ser capaz de operar milagres, se milagroso é o que interrompe o automatismo dos acontecimentos inaugurando o novo, o que torna o improvável realidade, que acontece, na verdade, todos os dias. 0 homem é livre enquanto, exercendo a si mesmo como único em sua singularidade capaz de iniciar o que inicia, manifesta através da própria existência com os outros a capacidade milagrosa de começar. Em outras palavras:

Fluindo na direção da morte, a vida do homem arrastaria consigo, inevitavelmente, todas as coisas humanas para a ruína e a destruição, se não fosse a faculdade humana de interrompê-las e iniciar algo novo, faculdade inerente à ação como perene advertência de que os homens, embora devam morrer, não nascem para morrer, mas para começar. (ARENDT, 2007, p. 258) 
SAÍDA, OU A FALTA DE UMA

\author{
Nesta vida sem sentido a coisa mais insensata me \\ parecia mais provável que a sensata $e$ \\ particularmente fecunda para minhas \\ investigações. \\ Franz Kafka, em "Investigações de um cão"
}

Hannah Arendt nos lembra, em algumas passagens de $A$ condição humana, que os criminosos são solitários, porque contra todos os homens (e os equipara, numa oposição simétrica, ao praticante de boas ações, a favor de todos os homens, colocando a ambos, no entanto, fora do mundo) e porque necessitam esconder-se dos outros, não podendo se revelar. Se eu considerasse que todos os homens e mulheres presos são apenas criminosos, esta pesquisa poderia ser inteira desconsiderada. Não digo que quase todos não tenham cometido crimes, mas me parece que, na maioria dos casos, esse é um acontecimento de sua história, muito determinante dela toda, porém que não determina eles não pertencerem mais à comunidade dos homens como o estigma que recai sobre quem está ou já esteve preso faz supor. Ainda que os contares aqui trazidos, pelo peso, quando o crime que os levou à prisão é assassinato, me custem tremendo esforço de "humanização", porque quando se mata concretamente um homem, mata-se também algo do humano que poderia existir dentro de quem a partir de então é chamado de assassino. Assassino do outro e também de si mesmo. Inevitavelmente.

Ao lado do esforço de "humanização", foi-me exigido também o de simbolizar de maneira minimamente digerível fatos tão indigestos. Diversas vezes me interrompi antes de conseguir pensar acerca de crimes considerados (também por mim) hediondos através de textos de que gosto, porque era (e é) impossível emprestar poesia ou graça ao horror se isso de alguma forma o ameniza ou banaliza. Temo que de alguma forma essa banalização possa ter ocorrido em meu contar e sei que dela se corre risco constante no dia a dia no CHSP. Recordo-me de um momento, num dia qualquer naquele hospital prisão, em que me atingiu subitamente a feiura, o absurdo, o horror de estar ali e que eu presenciava cotidianamente sem dele me assustar ou sequer dar conta. Foi um instante terrível que me impelia a correr 
daquele lugar para qualquer outro em que a beleza e a leveza se fizessem presente; um instante que incluía também a gigante pergunta do porquê de eu estar ali, e ainda mais: do porquê, quase incompreensível, de eu na maioria das vezes gostar de estar ali, de acordar nas manhãs disposta a rumar para lá. Tive que abafar o instante, senão teria ido embora. Mas ele me deu notícia da dissociação diária necessária para se estar diante do horror sem o sentir de forma paralisante.

O horror também deslumbra: desloca a luz, atrai de forma desconcertante porque, desde todos os tempos, também é do homem, mesmo que sombra. E atrai. 0 homem se vê magnetizado pelo feio, pelo terrível, pelo trágico; não fosse isso, não haveria tantos programas televisivos em que isso é o mote, não nos sentiríamos impelidos a ler as notícias sensacionalistas que nos oferecem dia a dia nos jornais, o trânsito não ficaria tão mais lento pelas pessoas reduzirem a velocidade para ver quando acontecesse um acidente na rua. Há um encontro entre o terrível e o belo: ambos são inacessíveis, paralisantes e fulminantes (ANDERS, 1969, p. 62). Mas o terrível, além de se oferecer para ser visto, também nos fita e nos pergunta:

Mas no belo em que o terrível ainda ou outra vez está contido, essa suposta estrutura essencial de "olhar" e "ser olhado" está totalmente invertida. A máscara da Górgona é, primacialmente, o exato oposto de um objeto de contemplação; ela mesma é "olhar", ou seja, "mau-olhado" - feita e destinada para quem olha continuar olhando ou para paralisá-lo completamente. (...) Não somos nós que a olhamos, é ela, antes, que nos fita. (op. cit. p. 65)

A perplexidade em que nos lança o olhar do terrível é algo que meu contar procurou manter quando percebi que minha dificuldade em simbolizar o horror não era minha: pertencia ao próprio horror. 0 indigesto deve permanecer indigesto, senão deixa de nos perguntar sua questão. 0 esforço na discussão que se segue não pretender dissolver culpas, amenizar absurdos, "deixar barato" através do que não tem preço através de interpretações e sobreposições. Acaso isto aconteça em algum momento, desculpo-me de antemão. Também é do homem compreender o incompreensível.

Não é só de horror que se constituem os crimes pelos quais os homens são condenados ao encarceramento. Estes são, certamente, a minoria, no entanto tão 
presentes nesta pesquisa talvez justamente pela minha impossibilidade em digerilos. Foi depois de escolher os presos internados com quem iria conversar acerca da liberdade que percebi que três deles eram homicidas - para mim, o pior crime ${ }^{24}$. Posso, assim, ter sido injusta porque percebi ao longo do tempo que, se algum benefício o que aqui escrevi poderia levar a quem está preso, este benefício seria que sua história fosse contada. 0 contar de sua história poderia dizer a todos que não estão presos que os que estão são gente, simplesmente porque é de gente que se pode contar uma história. A minha injustiça seria dar voz através de contar sobre pessoas que mataram e que perderam, neste momento, algo de sua humanidade arrancando no mesmo instante algo da humanidade toda -, deixando de contar das tantas outras que estão presas por todos os outros motivos que, apesar de contrariarem a lei, não contrariam em si nem nos outros a humanidade.

Voltando aos criminosos em geral: por já se encontrarem presos, eles não precisam mais se esconder - quem os esconde agora do mundo comum são as leis. Parece haver uma definição implícita em dizer que os criminosos precisam ocultarse (para não serem presos). É aquela definição de que, na prisão, fica quem está alheio, à margem do mundo, como se aparecer (e ir preso) retirasse do criminoso sua caracterização fundamental: o criminoso é aquele que não pode aparecer - ou a confirmasse ainda mais, porque se esconde de todos, mas agora na prisão. Porém, quando se tem a possibilidade de ir até onde se oculta o criminoso, tem-se a possibilidade de chegar ao homem que se esconde no "criminoso", como se nessa palavra coubesse tudo o que fizeram cada uma daquelas pessoas, por mais distintos que tenham sido seus crimes e supostas motivações.

Para falar de si, para contar a própria história, é preciso coragem:

E esta coragem não está necessariamente, nem principalmente, associada à disposição de arcar com as consequências; o próprio ato do homem que abandona seu esconderijo para mostrar quem é, para revelar e exibir sua individualidade, já denota coragem e até mesmo ousadia. Essa coragem original, sem a qual a ação, o

\footnotetext{
${ }^{24}$ Há pouquíssimas situações em que o crime de homicídio é, a meu ver, compreensível. Pensando acerca disso me veio à mente Amor, filme de Michael Haneke de 2012, em que matar parece ser o que mais faz sentido levar à cabo.
} 
discurso, e segundo os gregos, a liberdade seriam impossíveis, não é menor - pode até ser maior - quando o "herói" é um covarde. (ARENDT, 2007, p. 199)

Quem teve sua história contada aqui teve, ainda que por um momento, a coragem de me a revelar, e de revelar-se a si mesmo - e fazer-se a si mesmo através dela. A prisão é um lugar para onde confluem muitas histórias. Talvez este seja um dos motivos que respondam parcialmente à pergunta de porque gosto de "trabalhar" lá: porque gosto de escutar histórias.

Para que eu pudesse escrever a história de cada um dos que me a contaram, foi necessário que um encontro tenha se dado. Se existe qualquer encontro, aquele homem, mesmo que momentaneamente, já não é solitário. "Estar isolado é estar privado da capacidade de agir" (ARENDT, 2007, p. 201). Seria muito ousado de minha parte supor que meu testemunho possa ter propiciado ao homem que me contou sua história a possibilidade de agir - e então, alguma liberdade? Se “(...) a ação sempre estabelece relações, e tem portanto a tendência inerente de violar todos os limites e transpor todas as fronteiras" (op.cit., p. 203), seria possível que, contando-me sua história, cada um daqueles homens possa ter, dentro dos muros, preso, adoecido, experimentado a liberdade? Damião mesmo me responde essa pergunta quando diz que "Dentro da prisão a gente é livre não totalmente. Porque a gente é limitado. A gente é livre até certo ponto: eu posso vir aqui conversar com a senhora, ou com a psicóloga, com outros presos." A liberdade, Damião reconhecia, era sim poder falar e contar sua vida para alguém; disso já antecipara Arendt que "tomamos inicialmente consciência da liberdade ou do seu contrário em nosso relacionamento com os outros, e não no relacionamento com nós mesmos." (2011, p. 194). E quanto às histórias e às pessoas, continua Arendt dizendo que:

Onde quer que os homens viva juntos, existe uma teia de relações humanas que é, por assim dizer, urdida pelos feitos e palavras de inumeráveis pessoas, tanto vivas quanto mortas. (...) É por causa desta já existente teia de relações humanas, com suas vontades e intenções conflitantes, que a ação quase nunca atinge seu propósito. E é também por causa deste meio e do traço de imprevisibilidade que o acompanha que que a ação sempre produz estórias, com ou sem intenção, tão naturalmente quanto a fabricação produz coisas tangíveis. Essas estórias podem então ser registradas em documentos e monumentos, ser contadas na poesia e na historiografia e inseridas em todo tipo de material. Elas mesmas, todavia, são de uma natureza inteiramente diferente dessas reificações. Tais histórias nos dizem 
mais acerca de seus sujeitos, o "herói" em cada estória, do que qualquer produto das mãos humanas jamais nos conta acerca do mestre que o produziu em apesar disto, não são produtos, propriamente falando. Embora todos iniciem sua própria estória, ao menos a estória de sua própria vida, ninguém é o autor ou produtor dela. E, no entanto, é precisamente nessas estórias que a verdadeira significação de uma vida humana finalmente se revela. (2005, p. 192)

Damião também me havia dito da liberdade de sua mente: "A gente voa, vai pra qualquer lugar e volta pro lugar que estou e pra tudo aquilo que aconteceu." É importante diferenciar tal liberdade da que acontece com o outro. Para tanto, também nos auxilia Arendt:

A liberdade que admitimos como instaurada em toda teoria política e que mesmo os que louvam a tirania precisam levar em conta é o próprio oposto da "liberdade interior", o espaço íntimo no qual os homens podem fugir à coerção externa e sentirse livres. (2011, p. 192)

O próprio "voar, ir pra qualquer lugar", como o coloca Damião, da "liberdade interior", parece em alguns momentos acontecer não dentro, mas do lado de fora: na comunidade dos homens. Quando isso ocorre é quando se dá a liberdade, no encontro de um voo singular com os homens todos: o sentido. Como nos diz SaintExupéry:

Queremos ser libertados. 0 que dá uma enxadada no chão quer saber o sentido dessa enxadada. E a enxada do forçado, que humilha o forçado, não é a mesma enxada do lavrador, que exalta o lavrador. A prisão não está onde se trabalha com a enxada. Não há o horror material. A prisão está onde o trabalho da enxada não tem sentido, não liga quem o faz à comunidade dos homens. (2006, p. 133)

Quem está preso viveu o fim de sua história, pelo menos de uma parte dela, porque o aprisionamento é o recado da sociedade a quem cometeu o crime de que aquela vida, como era, chegou ao fim (embora continue, de outra forma, intramuros). Uma história só pode ser contada como tal depois que termina, senão nunca poderia ser fixada: tudo o que acontece depois tem sempre o poder de presentear ao que já tinha se dado novos significados. "Ele é feliz? Pela maioria das medidas, sim, ele acredita que é. No entanto, ele não se esqueceu do último coro de Édipo: Não diga feliz um homem até sua morte." (COETZEE, p. 2. Tradução livre minha). Com todas as ressalvas que tal afirmação exige, poderia se dizer que, sob o 
aspecto de estar "além da história", a prisão pode ser privilegiada por poder colocar, quanto à história que se findou com o aprisionamento, seu quem, não definitivo, como seria com a morte biológica, mas temporário e provisório; porque, "muito embora as histórias sejam resultado inevitável da ação, não é o ator, e sim o narrador que percebe e "faz" a história." (ARENDT, 2007, p. 205)

Mas não bastam fatos para que se faça história. É preciso que se esteja entre os homens, naquela comunidade dos homens de que disse acima. Na prisão, porém, a experiência de comunidade é extremamente limitada, como já vimos por aqui: gestos aparados em movimentos automáticos e conversas restritas a assuntos de crime e religião possíveis de se dar somente de forma tão impessoal, como se ambos fossem ali os reversos da mesma moeda, a moeda do não poder ser si mesmo, paga dia a dia para sobreviver à cadeia.

Se o que me contaram aquelas pessoas foi suficientemente dito por elas e ouvido por mim para que fosse feito história então são exemplos de ação, mesmo que sua constituição central seja considerada crime pela sociedade. Muitos crimes acontecem justamente porque uma das características da ação é sua imprevisibilidade; e são irremediáveis, se não perdoáveis, porque outra de suas características é a irreversibilidade. Ainda assim, seria possível dizer que, por serem tornáveis história, este tornar enquanto ação poderia significar liberdade - uma maneira, então, de experimentá-la mesmo dentro da prisão? Para Damião, parece que sim. Para Gregório, que atendi nas minhas primeiras semanas no CHSP, também: ele, com um brilho irredutível nos olhos, respondendo às perguntas que eu fazia sobre sua vida, confessara que nunca havia falado nada daquilo para ninguém. Alegres, ele e eu, diante da sua descoberta de poder contar os fatos de sua vida fazendo-os história.

Olho agora para a alegria que senti naquele momento: parte dela vinha de crer que abundariam instantes como aquele no meu trabalho no CHSP, o que não aconteceu, talvez porque eu mesma tenha embrutecido minha escuta e meu olhar como forma de me proteger do medo que cria não sentir ou talvez por tanto submetê-los a gente submetida a tratamento que não é para ser de gente (e nem de bicho, nem de nada, porque ninguém é tão indigno que caiba perfeitamente na 
prisão e porque a indignidade da prisão tira o que é digno de todos os homens). Ou de tanto tentar costurar história onde isso não seria possível - porque sempre são necessários mais de um, e não poucas vezes me vi sozinha diante do outro que continuamente se retirava. Ilana, por exemplo. A primeira vez que falei com ela disse-me de sua infância terrível, da morte precoce de sua mãe, de seu crescimento no setor de órfãos da então FEBEM, de onde saiu para morar na rua e usar crack. Compadeci-me e até estranhei o que me relataram em seu encaminhamento: ela era agressiva, tumultuava a ala, arranjava confusão com todo mundo. Falta de quem a escutasse, pensei, ingênua. Passados alguns meses, num final de semana, sou chamada para avaliar uma paciente que havia vindo para uma consulta ambulatorial, não fora levada "de bonde" no mesmo dia e estava apresentando uma crise de agitação. Não reconheço Ilana (eu a havia atendido apenas uma ou duas vezes antes de sua alta) e pergunto-lhe toda sua história sem ter acesso ao seu prontuário. A primeira coisa que me diz é que sua mãe está detida na mesma unidade e se ela não voltar logo para lá, vai ficar muito preocupada. Por isto estou nervosa, doutora. Aquela mesma mãe que havia falecido anos antes destinando-a à FEBEM, pude saber depois, conforme li na minha própria letra em seu prontuário.

Os fatos não precisam ser verídicos para se fazerem história, mas se tenho a esperança de me deparar com a história de alguém, este alguém precisaria estar ali, mesmo que inacessível. A mentira sempre tem um sentido, penso agora, e não necessariamente de valoração pejorativa. Mas se o único sentido é enganar o interlocutor com o intuito de obter benefícios, então não há história possível que se tire dali! Pelo menos, não que eu consiga ver. Quando isso acontece, cessa o encontro possível, porque cessa o des-inter-esse no qual ele verdadeiramente poderia se dar. Na mesma direção, oposta ao encontro, vão as falas tão comuns que buscam adivinhar o que eu gostaria de escutar ao invés de perscrutar quem poderia falar de si; aquelas falas que evitam dizer qualquer coisa de quem diz e até mesmo aquelas quando, por exemplo, eu perguntava sobre a liberdade e escutava as respostas do senso comum: ir para onde quiser, fazer o que eu quiser. Justo eles!, que pensei ter tanto a me dizer acerca da liberdade e de sua privação. Talvez eu não tenha perguntado propriamente; ou talvez a prisão também signifique isto: a 
impossibilidade de refletir. Seja pela falta do silêncio fecundo, seja por uma falta anterior, a mesma, quem sabe, que levou muitas das pessoas a estar ali: falta de quem as olhasse como gente, de quem acreditasse que pudessem pensar - pois a quem poderia acreditar havia também recaído, antes, a mesma falta: perpétua impossibilidade -, da sorte de ter quem testemunhasse seu aparecimento como gente, ou todas elas, ou a mesma. Como diz Goffman, o mundo anterior pode ter sido tão terrível que a prisão e suas restrições não se configuram como grande novidade: "Às vezes, no entanto, o mundo habitual do internado foi de tal ordem que o imunizou contra o sombrio mundo da instituição; nesses casos, não há necessidade de levar muito longe um esquema específico de adaptação." (2013, p. 63)

Quanto à impossibilidade de refletir que talvez possa significar a prisão, percorro novamente os caminhos a que meus próprios pensamentos, conversas e leituras me levaram. Cheguei a conjecturar que o aprisionamento, "interrompendo" temporariamente a história de uma pessoa no mundo fora da prisão e oferecendo tempo para pensar, pudesse trazer benefícios, arrependimentos, novos sentidos às coisas já dadas. Isto, no entanto, é muito difícil de acontecer, por alguns motivos. 0 primeiro é simples: o mundo lá fora não para, só a história da pessoa que saiu dele. Há um descompasso, sentido e vivido como perda por quem está preso. 0 filho que andou, a avó que adoeceu, o companheiro de trabalho que subiu de cargo, o pai que morreu, o Natal que passou a cada ano, todos os carnavais que não se pulou. Não se ganhou tempo para pensar: perdeu-se tempo de viver. Tempo irrecuperável, com consequências também irreparáveis. Como diz Goffman, "Não apenas sua posição social intramuros é radicalmente diversa da que era fora, mas, como chega a compreender se e quando sai, sua posição social no mundo externo nunca mais será igual à que era." (2013, p. 68)

O tempo na prisão é morto: não oferece nada que possa ser levado de volta ao mundo lá fora e não é facilmente preenchido para que passe mais rápido lá dentro. Não há quase lazer com que o ocupar. Tampouco é um tempo que se dê à reflexão, porque não é qualquer tempo que se dá a isso. Nicolae Steinhardt, um monge romeno que escreve acerca de seus anos na prisão em $O$ Diário da Felicidade, diz acerca da dificuldade em se lidar com o tempo durante a reclusão forçada: 
"Tortura sem instrumentos, através do colocar face a face, no vazio, de duas entidades: o homem e o tempo puro. Tortura pelo Tempo. 0 Homem e o Tempo, nada mais que isso: enchê-lo!" (2009, p. 331) Steinhardt, mesmo sendo um homem que se dedicava a pensar e refletir, aponta para a dificuldade de tornar o tempo frutífero para o pensamento na prisão. Isto pelo que já dissemos anteriormente: a restrição do espaço público, do espaço privado e da separação entre eles, dificultando, muito simplificada mas respectivamente, as experiências coletivas, a profundidade e a brecha entre ambas, em que se poderia dar a reflexão.

Steinhardt, homem de muita fé, consegue enxergar a possibilidade de que a prisão possa engrandecer o homem:

Creio assim: que se saíres da prisão e por causa do sofrimento ficas com vontades de vingança e com sentimentos de acridão, a prisão e os sentimentos foram sem proveito. Mas se o resultado é um complexo de tranquilidade e compreensão e de nojo diante de qualquer violência ou esperteza, significa que os sofrimentos e a prisão foram úteis e têm que ver com os caminhos incompreensíveis em que apraz a Deus andar. 0 poder de amar, na saída da prisão, tem de ter crescido em proporções inimagináveis. (2009, p. 333)

Creio assim, eu: que os benefícios que ele teve foram proveito de sua fé e não da prisão. Não conheci ninguém, nos mais de dois anos em que trabalho no CHSP, que tenha se tornado uma pessoa melhor, qualquer que seja o significado disto, pelo fato de estar preso ou de qualquer experiência decorrente unicamente do aprisionamento. Se há quem possa se beneficiar da experiência da prisão, isto se deve a características anteriores ao encarceramento, e estas pessoas poderiam crescer como pessoas em qualquer situação. Conjecturo a partir daí quanto à diferença entre o preso político e o preso comum, apesar de não ter conhecido nenhum preso político no CHSP: é mais difícil que o segundo se beneficie da prisão porque muito provavelmente lhe falta algo anterior, algo quase impossível de a prisão suprir. Foi muito provavelmente esta falta que trilhou seu caminho até detrás das grades. 0 que levou o preso político à prisão, de modo muito diferente, pode ser justamente o motivo que o faça suportá-la melhor: uma causa. Na mesma direção vai Goffman ao colocar que "convicções religiosas e políticas profundas servem para isolar o crente autêntico dos assaltos de uma instituição total." (2013, p. 63) 
Breno em uma noite destruiu a história que havia construído para si e todo seu abrigo real e possível ${ }^{25}$. Uma noite apagada da memória, porque assombrada por um ato violentamente brutal, sem destino e sem sentido. Ele, durante meses, vive a desmemória como limbo da própria vida porque sua vida já não existe mais e porque para voltar a viver ele precisa antes morrer. Ao limbo pertencia seu dizer: estava apenas internado num hospital, não cumprindo pena numa prisão. (Ele não chegara a ir para uma prisão convencional. Foi da cena do crime a um hospital comum, de lá ao CHSP, onde permaneceu até receber alvará de soltura, alguns meses depois). Talvez porque soube do adoecimento de sua avó e da impossibilidade de voltar a vê-la caso viesse a morrer, Breno se deu conta de que estava preso, e que cumpria uma pena. "Estou me preparando para a pena máxima", ele dizia. Algo em seu dizer, o vigor daquele preparar-se que transparecia em sua voz, era quase um apego àquela pena. Cumprir a pena era o que poderia dar alguma consequência a seu ato absurdo, aparentemente descolado do passado e destruidor do futuro. Cumprir a pena destinaria sua ação, e então ele poderia construir sua história. Porque "a realidade cria fatos. 0 homem costura-os e faz história." (POMPEIA e SAPIENZA, 2004, p. 97)

Isto não é um elogio à prisão. A própria dissociação anterior de Breno fala da prisão como algo que não é necessariamente nem sentido como pena ou castigo. Breno, a partir de certo momento, pode assumir a pena que ele mesmo havia imposto à própria vida, que se traduzia concretamente como limbo-prisão. Pode então assumir a responsabilidade e sentir a culpa: "conflito (...) entre o que fui capaz de ser e a pessoa que eu gostaria de ser." (op.cit, p. 92); pode comprometer-se com sua própria ação, transformando punição, a mera produção de sofrimento, em castigo, de castos: o resgate da pureza da integridade, que é o oposto da dissociação. 0 castigo e a punição relacionam-se com a dinâmica do perdão. Nos diz Arendt, quanto ao perdão e à punição:

25 Devo e agradeço a reflexão que se segue a Guto Pompeia, durante uma de suas iluminadoras supervisões. 
Ao contrário da vingança, que é a reação natural e automática à transgressão e que, dada a irreversibilidade do processo da ação, pode ser esperada e até calculada, o ato de perdoar jamais pode ser previsto; é a única reação que atua de modo inesperado e, embora seja reação, conserva algo do caráter original da ação. Em outras palavras, o perdão é a única reação que não re-age apenas, mas age de novo e inesperadamente, sem ser condicionada pelo ato que a provocou e de cujas consequências liberta tanto o que perdoa quanto o que é perdoado. (...) A punição é a alternativa do perdão, mas de modo algum seu oposto; ambos têm em comum o fato de que tentam pôr fim a algo que, sem a sua interferência, poderia prosseguir indefinidamente. É, portanto, significativo (...) que os homens não possam perdoar aquilo que não podem punir, nem punir o que é imperdoável. (2007, pp. 252-253)

O castigo (punição, como coloca Arendt) para Breno constitui-se como o percurso que vai da dissociação para a integridade, e inicialmente dói. 0 castigo, para Breno, é olhar para o que ele mesmo fez; é do feito que pode aparecer algum caminho e o feito é a morte do que era antes sua história. Ele precisaria morrer essa morte causada por ele e começar de novo como reparação carregando o que nunca vai ser possível reparar. Algo inacabável, sem fim: sua reparação é um jeito de viver. A liberdade, para Breno, como simultâneos perdão e castigo, começa na prisão, na assumpção da própria pena. Assim como Hércules e seus doze trabalhos, assumidos depois que o herói mata os filhos num ataque de fúria. Ele continua preso à vida porque não morreu e por isso estranha o fato de ter sobrevivido, mas está mais preso que o que a prisão é capaz de limitar. Para Breno, perdoar-se é o maior castigo.

Goffman menciona algum tipo de alívio que o tormento decorrente de se estar numa instituição total pode gerar: "A mortificação ou mutilação do eu tendem a incluir aguda tensão psicológica para o indivíduo, mas para um indivíduo desiludido do mundo ou com sentimento de culpa, a mortificação pode provocar alívio psicológico." (p. 49) Para quem a culpa sufoca, cumprir o castigo a ameniza: a dor da culpa, em si irremediável, é deslocada para a dor da pena, que então remedia. Mas até mesmo a culpa pode faltar. Raskólikov, que em Crime e castigo comete um homicídio, nos aproxima disso em suas reflexões:

Oh, como seria feliz se pudesse acusar-se a si próprio! Aí suportaria tudo, até a vergonha e a humilhação. Mas ele fez um julgamento severo de si mesmo, e sua consciência obstinada não descobriu nenhuma culpa especialmente terrível no seu 
passado, a não ser uma simples falha que podia acontecer a qualquer um. (DOSTOIÉVSKI, p. 553)

Pode acontecer a qualquer um matar alguém? Esta é uma pergunta que já havia me ocorrido diante de Breno. Qualquer pessoa seria capaz de matar? Ou será que a impossibilidade da memória, no caso de Breno, responderia a esta pergunta negativamente - porque não lembrar o redimia de alguma forma, como se não coubesse em sua vida, em sua memória, haver matado? Quem matou, então, senão ele? Se não ele quem matou, quem morreu?

Há alguma diferença entre o matar de Breno, dono de uma vida que ele mesmo prezava, em que nada parecia faltar (exceto a confiança em sua esposa, falta que, segundo dizia, motivou seu crime) e as mortes levadas a cabo por Tomás, que se dizia vítima da própria vida e assim tentava se desculpar? Já havia antes alguma falta?

Recorro ao rosto oferecido por Emmanuel Levinas para tentar pensar acerca destas questões. 0 que é o rosto? Rosto é o que não se vê quando se observa a face de alguém atentando para seus detalhes: o formato e a cor dos olhos, a boca, a testa, o nariz. Rosto é o que tampouco se vê quando se reconhece alguém como personagem da própria vida, com sua profissão, seu papel, seu jeito de se vestir e se apresentar. 0 acesso ao rosto não se dá através dos sentidos ou do que se conhece ou quer conhecer a respeito de alguém. “(...)O acesso ao rosto é, num primeiro momento, ético." (LEVINAS, 2013, p. 69) Rosto é onde se oferece o encontro possível entre os homens. Levinas diz:

Em primeiro lugar, há a própria verticalidade do rosto, a sua exposição íntegra, sem defesa. A pele do rosto é a que permanece mais nua, mais despida. A mais nua, se bem que de uma nudez decente. A mais despida também: há no rosto uma pobreza essencial; a prova disto é que se procura mascarar tal pobreza assumindo atitudes, disfarçando. 0 rosto está exposto, ameaçado, como se nos convidasse a um acto de violência. Ao mesmo tempo, o rosto é o que nos proíbe de matar. (op. cit. pp. 69-70)

O homicídio não escuta a proibição dita pelo rosto porque o homicida não consegue enxergar o rosto do outro nem o próprio. Esta última impossibilidade, 
creio não ser exclusiva do homicida: o próprio rosto ninguém consegue enxergar, justamente porque cabe ao outro fazê-lo. É só diante do outro que o rosto aparece como tal. A quem mata, no entanto, falta poder ver o rosto do outro: falta a possibilidade do encontro, provavelmente desde antes, desde sempre, desde que um rosto tampouco lhe foi dado pelo olhar do outro diante de si.

O convite ao ato de violência oferecido pela nudez do rosto, pela fragilidade de todos os homens exposta no simples estar diante do outro, seria, no encontro, imediatamente sempre recusado; mas quando o encontro falta, mantém-se pairando como convite, e os homens passam então a ser sempre os mesmos, a quem se pode matar.

0 rosto é significação, e significação sem contexto. (...) Tu és tu. Neste sentido, pode dizer-se que o rosto não é "visto". Ele é o que não se pode transformar num conteúdo, que o nosso pensamento abarcaria; é o incontível, leva-nos além. (...) 0 rosto é o que não se pode matar ou, pelo menos, aquilo cujo sentido consiste em dizer: "tu não matarás." (op.cit, p. 70)

Ausência de rosto e de encontro que possibilita à história o seu contar pode se dar mesmo diante de outra pessoa, como parece ser o caso de Tomás. Como é ruim estar diante de uma pessoa sem ser enxergada como rosto. Como é ruim ser coisa na frente de alguém. Não há rosto, não há encontro e não há liberdade.

É impossível a liberdade na ausência do outro. Se o ser do homem é livre e é si mesmo, isto implica que é com-o-outro, condição originária do homem. Hannah Arendt contrapõe a liberdade com a ausência do outro através da identificação desta última com a soberania - situação não de solidão, que contém o outro através de sua ausência, mas de isolamento, que se for solidão, é uma solidão seca, opaca, porque excludente do outro. Ela diz:

Sob condições humanas, que são determinadas pelo fato de que não é o homem, mas são os homens que vivem sobre a terra, liberdade e soberania conservam tão pouca identidade que nem mesmo podem existir simultaneamente. Onde os homens aspiram a ser soberanos, como indivíduos ou grupos organizados, devem se submeter à opressão da vontade, seja esta a vontade individual com a qual obrigo a mim mesmo, seja a "vontade geral" de um grupo organizado. Se os homens desejam ser livres, é precisamente à soberania que devem renunciar. (2011, p.213) 
De tal maneira estão imbricadas a liberdade e a pluralidade dos homens que, para subjugar alguém que seja livre, basta isolá-lo. 0 isolamento é, assim, absolutamente contraditório com, e impeditivo da liberdade. Já sabia disso Etienne de la Boétie:

Ora, comumente, ficam sem efeito o bom zelo e afeição dos que apesar do tempo conservaram devoção à franquia, por mais numerosos que seja, porque não se conhecem; sob o tirano, é-lhes tirada a liberdade de fazer, de falar, e quase de pensar: todos se tornam singulares em sua fantasia. $(1982$, p. 24)

Tomás parece estar impossibilitado de ser verdadeiramente tocado pela presença do outro. As pessoas se diminuem, em seu existir, a meros personagens de uma história da qual nunca poderão tomar parte, a menos como causadores do que eu chamarei de sentimentos longínquos, que não chegam a ser experimentados a não ser à distância e cuja proximidade parece ser insuportável a ele. Aniquilar a pessoa que lhe cause qualquer frustração é equivalente a, por um momento, idealizar alguém que lhe "forneça" alguma satisfação. Em ambos os casos o outro é tratado como uma coisa. Mas o homem que está por detrás da coisa-humana de Tomás morre de verdade se é atingido por um tiro que ele disparou. Eu morri apenas um pouco, sentindo-me encolher a esse estado coisificado quando, escutando Tomás, lhe proporcionei o que ele sentiu como satisfação - e com que prazer ele se percebia escutado; um prazer que crescia à medida que eu diminuía, me afastando de ser gente em direção a ser coisa. Enquanto eu era uma face diante de outra face, ambas destituídas de rosto, pois que não houve encontro que o concedesse.

A liberdade nunca pode ter relação com a violência. Se através da liberdade o homem se exerce como si mesmo, dizendo ao mundo, mesmo sem palavras, quem ele mesmo é, através da violência não se diz nada. A violência se configura, sempre, como desproporcional à situação que a engendrou; não pode caber; se o homem fala, a violência é muda e emudece o homem que, assim, fica impossibilitado da própria liberdade. Hannah Arendt aponta-nos que "Somente a pura violência é 
muda, e por este motivo a violência, por si só, jamais pode ter grandeza." (2007, p. 35) Não é à toa que em Prometeu Acorrentado, tragédia escrita por Ésquilo para contar dos pesares de Prometeu como castigo à doação do fogo aos mortais, a Violência é a única personagem que nada diz: nos rochedos da Cítia, ao lado do Poder, de Vulcano e do próprio Prometeu, a Violência é muda.

Tomás não pode ser livre, nem chegar perto do que significa a liberdade, nem ao menos através de sua privação, porque é sozinho na forma do isolamento. Por isto tudo o que ele me dizia parecia oco. Não há nele o outro que lhe possa fecundar a palavra. Por isto me senti destruída: porque se retrai o outro possível que o seja capaz de escutar. Encolhi enquanto o outro de Tomás.

Gonçalves Filho nos aponta para a idiotia:

Idios, no grego, é a palavra indicativa do que é próprio; idioteía preparou o nosso idiotia, então correspondendo a uma concentração no que é próprio, um zelo exagerado pelo que sou eu ou é meu, pelo que somos ou é nosso, em detrimento e contra o que é alheio, estrangeiro, outro. (2007, em trecho suprimido da versão publicada segundo o próprio autor)

A impossibilidade do outro, do alheio, do estrangeiro impede a existência também do igual que é o diferente no sentido de possibilidades do outro que, como irmanado na mesma condição de homem, poderiam ser minhas. A humanidade se restringe, se ceifa em seus infinitos possíveis; há um empobrecimento atroz. A liberdade também é inevitavelmente barrada pelo impedimento do "despertar da resposta da co-existência no ser-com, com o qual ele (o homem: ser-aí) pode sacrificar a egoidade para se conquistar como autêntico si mesmo." (HEIDEGGER, 2008, p. 188)

Etienne de la Boétie, consagrando a amizade, aponta para o ser-com, esterilizado na idiotia em que se amarra Tomás.

A amizade é um nome sagrado, é uma coisa santa; ela nunca se entrega senão entre pessoas de bem e só se deixa aparecer por mútua estima; se mantém não tanto através de benefícios como através de uma vida boa; o que torna um amigo seguro do outro é o conhecimento que tem de sua integridade; as garantias que tem são sua bondade natural, a fé e a constância. Não pode haver amizade onde está a crueldade, a deslealdade, onde está a injustiça; e entre os maus, quando se juntam, há uma 
conspiração, não uma companhia; eles não se entre-amam, mas se entre-temem; não são amigos, mas cúmplices. (1982, p. 36)

A amizade só existe na liberdade e ambas na igualdade, porque ser-com é pressuposto de todas elas. Ser-com, que modifica o ser simplesmente. 0 com: o outro que a cada vez prevalece sobre mim através da ética, aquela através da qual se acessa o rosto.

O "Tu não matarás" é a primeira palavra do rosto. Ora, é uma ordem. Há no aparecer do rosto um mandamento, como se algum senhor me falasse. Apesar de tudo, ao mesmo tempo o rosto de outrem está nu; é o pobre por quem posso tudo e a quem tudo devo. (LEVINAS, 2013, p. 72. Grifo meu)

Talvez, quando Damião disse ter feito mal a si mesmo através de seus crimes, ele não estivesse se referindo às consequências deles no trajeto de sua vida, como a prisão. Talvez ele estivesse dizendo da responsabilidade para com o outro, do dever tudo ao outro, que ele, descumprindo, teve que arcar como mal a si próprio. Estaria ele, então, possibilitado de enxergar o rosto no outro? Matar alguém mata definitivamente a possibilidade de encontro? Ou a morte dessa possibilidade já existia antes?

É o dever tudo ao outro que fala na voz de Steinhardt quando o monge se aproxima da culpa. Não culpa pelo que se fez, pois ela pode vir sem crime algum, e porque o crime não garante o sentimento de se sentir culpado, como nos mostrou de relance Raskólnikov. Uma culpa pelas impossibilidades e faltas de todos os homens, porque são outrem que não eu, e por isso cada gesto ou ação me cabem como responsabilidade através da humanidade de seu rosto.

0 primeiro efeito do encarceramento, acentuado pelos sinos: o sentimento de culpa. Embora estejamos aqui por causa de algumas acusações fantasiosas, percebemos inteiramente uma culpabilidade geral: diante de nós mesmos, da vida, dos homens. Somos inocentes quanto às acusações que nos fazem, mas oh!, quão culpados quanto a todo o resto. Levamos nos ombros, nas costas, na alma, os pecados do mundo. (STEINHARDT, 2009, p. 160)

A culpa por cada crime que o outro cometeu também, de certa forma, me pertence enquanto possibilidade. Dentro da prisão e fora; a culpa por cada crime 
que quem está na prisão cometeu e não cometeu pertence também a quem não está preso. E vice-versa. Por isto a necessidade de se contar a história dos homens que não somos nós. Para que tenham rosto e para que sua culpa pertença à humanidade - o que não significa redenção desta culpa.

Até de Tomás, entretanto, se pode contar uma história. Talvez a história da liberdade impossível, que paradoxalmente poderia se constituir como a possibilidade da liberdade no momento em que se contasse. Porque

A principal característica desta vida especificamente humana, cujo aparecimento e desaparecimento constituem eventos mundanos, é que ela, em si, é plena de eventos que posteriormente podem ser narrados como história e estabelecer uma biografia. (...) Pois a ação e o discurso (...) são realmente duas atividades cujo resultado final será sempre uma história suficientemente coerente para ser narrada, por mais acidentais ou aleatórios que sejam os eventos e as circunstâncias que os causaram. (ARENDT, 2007, p. 109)

A liberdade como começo nunca deixa de ser possível, mesmo que seja reiterada e eternamente impedida e nunca chegue a se realizar. Por isto se pode falar em liberdade na prisão; talvez pelas possibilidades cerceadas, é justamente aí que se cumpra verdadeiramente o começar. Como o imprevisível, improvável, praticamente impossível: o milagre.

O que permanece intacto nas épocas de petrificação e de ruína inevitável é a faculdade da própria liberdade, a pura capacidade de começar, que anima e inspira todas as atividades humanas e que constitui a fonte oculta de todas as coisas grandes e belas. Mas enquanto essa fonte permanece oculta, a liberdade não é uma realidade tangível e concreta; isto é, não é política. É porque a fonte da liberdade permanece presente mesmo quando a vida política se tornou petrificada e a ação política, impotente para interromper processos automáticos, que a liberdade pode ser confundida tão facilmente com um fenômeno essencialmente não político; em tais circunstâncias, a liberdade (...) é vivenciada (...) como um dom supremo que somente o homem, dentre todas as criaturas terrenas, parece ter recebido, e cujos sinais e vestígios podemos encontrar em quase todas as suas atividades, mas que, não obstante, só se desenvolve com plenitude onde a ação tiver criado seu próprio espaço concreto onde possa, por assim dizer, sair de seu esconderijo e fazer sua aparição. (ARENDT, 2011, p. 218) 
A liberdade me pareceu ser coisa diferente do que o que eu costumeiramente pensava quando percebi que na prisão algumas pessoas podem "ficar bem", adaptarse. Damião nos conta disto, quando deixa passar seus dias na cela do seguro sem sofrer. Mas eu estava equivocada.

0 acostumar-se à prisão não liberta o homem, como eu previamente havia pensado, mas é seu verdadeiro aprisionamento no sentido de destruição da liberdade. É quando o homem se acostuma à prisão que ele perde sua liberdade como capacidade de começar. Trata-se do automatismo, que nem de longe é exclusividade de quem vive encarcerado. Por isso é tão possível estar preso tanto fora quanto dentro do presídio. Referindo-se aos automatismos, Arendt nos diz que

É da natureza dos processos automáticos a que o homem está sujeito, porém no interior dos quais e contra os quais pode se afirmar através da ação, só poderem significar ruína para a vida humana. Uma vez que os processos históricos e artificiais se tenham tornado automáticos, não são menos destruidores que os processos vitais naturais que dirigem nossos organismo e que em seus próprios parâmetros, isto é, biologicamente, conduzem do ser para o não-ser, do nascimento para a morte. (2011 p. 217)

É a liberdade, como capacidade humana do começo, que dá ao homem a ocasião de escapar à inexorável ruína que nos equipara a todas as coisas e a tudo o que há que não é humano. É a liberdade o próprio elemento humano, através da qual se instaura o novo no mundo.

Poder-se-ia dizer que o nascimento de uma criança, instaurando o novo no mundo, caracterizar-se-ia como uma forma de liberdade e então ter filhos poderia significar vivenciar a experiência da liberdade dentro da prisão? Não, pensando as atividades humanas e a liberdade segundo Arendt. Primeiro porque a fertilidade não está no escopo da ação, enquanto sobrevivência da espécie, mas do trabalho - e a expressão "trabalho de parto" vem reiterar este âmbito. Segundo porque a liberdade acontece quando se dá outro nascimento do homem que não o primeiro, confirmando-o porém não com ele coincidindo. Em seu primeiro nascimento, biológico, o homem nasce enquanto membro da espécie humana; no segundo, 
através da ação, ele nasce enquanto quem ele mesmo é, singular, realizando o que somente ele e mais ninguém poderia.

Mesmo não podendo a princípio ser interpretado como expressão de liberdade, é belo este primeiro nascimento, mesmo quando ocorre na prisão.

\footnotetext{
- E belo porque com o novo

Todo o velho contagia.

-Belo porque corrompe

com sangue novo a anemia.

-Infecciona a miséria

com vida nova e sadia.

-Com oásis, o deserto,

com ventos, a calmaria.

(MELO NETO, 1994, p. 59)
}

É certamente a presença das crianças que faz da ala D um espaço completamente diferente de todo o resto do CHSP. A começar pelo tempo que ali transcorre. Não é o tempo da pena cumprida, vazio e morto, mas o tempo em que o recém nascido se desenvolve e precisa ser cuidado. 0 tempo em que ele sustenta a cabeça, senta, sorri. Andar, não, porque o trânsito amamentação é de seis meses, às vezes esgarçados para alguns mais. É o tempo de dar banho, lavar suas roupas, cuidar da cela para que ela esteja limpa para abrigar um bebê.

É a ala mais barulhenta e não só pelos barulhos que fazem as crianças. A comunicação entre as mães é certamente muito mais dinâmica que entre quaisquer outros internos. Ali elas não são só presas, elas são mães que têm que cuidar dos filhos, apesar de que o tempo para isso esteja com fim previamente delimitado.

A hora da "entrega" é quase sempre temida. A perspectiva de não ter mais o filho nos braços é trágica sob múltiplos aspectos. Primeiro, pela distância abrupta que de repente se fará, quando algum agente de segurança vier ao portão da ala e gritar pelo nome da mãe, sem que ela nada possa fazer exceto deixar seu filho aos cuidados de outra pessoa, com sorte um familiar. Algumas mães se recusam a entregar e vão de bonde para a unidade de origem com o filho, porém lá, segundo o que se diz acontecer (eu nunca fui a uma unidade prisional para verificar) é que as condições para se cuidar do bebê são tão ruins que as mães sempre o acabam 
entregando. Depois, porque o tempo voltará a ser o tempo morto da prisão, em que se perderá ademais a cada dia algo que se passou no crescer do filho. "Mas não é justo que eles fiquem aqui com a gente, neste lugar horrível.", muitas mães dizem. Uma pergunta sem resposta: se o melhor lugar para que um filho cresça é ao lado da mãe, ainda que na prisão.

0 momento da entrega: algumas choram e todas sentem a dor que, mais tempo, menos tempo, será também sua. Eu não vou aguentar, eu prefiro morrer, já escutei tantas vezes de mães que preveem o insuportável. Para outras, não é tão difícil. Outras ainda sentirão não a falta do bebê, mas a do pai, que suspeitam que as deixe de visitar assim que o filho mútuo já não esteja em suas mãos. 0 que de fato não raras vezes acontece. Outras nunca chegaram a receber visita do pai do filho, por ele também estar preso, por já ter morrido ou porque simplesmente não apareceu.

Já atendi a algumas mães que vieram a consulta ambulatorial passadas algumas semanas da entrega. Olheiras debaixo dos olhos e um vazio nas mãos maior que o de quem não carregava o filho há pouco tempo. Presas comuns, agora, sem nada que comprove a imensa dor que recém viveram, sem nada aparente que explique aquela falta de jeito por detrás dos gestos. Algumas seguem acompanhadas agudamente por aquela dor. Outras se empenham no trabalho para remição da pena e a perspectiva de poder viver perto do filho mais rápido, parecendo assim se organizar diante do tempo vazio da prisão sobreposto ao tempo repentinamente privado de cuidar de seu bebê.

Na ala D as mães se ajudam no cuidado para com os filhos. Quando uma está no banho, a outra olha e se outra apresenta um quadro depressivo limitante as outras assumem algumas tarefas. Porém, há regras que vigem paralelas a este cuidado aparentemente solidário. Uma hierarquia decide quem tem e quem não tem berço; ela vale mais que uma ordem médica para que a criança durma com o colchãozinho levantado por conta de refluxo, por exemplo. A quantidade de leite e fraldas também respeita esta hierarquia, cujo esquema de posições desconheço.

Bixima, estrangeira, sem visita, sem pertences, certamente ocupava uma posição muito baixa na hierarquia da ala D. Também por isso para ela tudo era 
difícil, como sempre repetia. Era lavando roupa de outros bebês e fazendo favores diversos que obtinha por exemplo roupa para seu filho. Um cansaço constante; mas este seu cansaço era justamente sua força. Além da sobrevivência, a entrada na hierarquia à qual ela não tinha como não pertencer.

Se o nascimento do filho não consiste, por si, em liberdade no sentido arendtiano, o nascimento do filho de Bixima talvez possa nos fazer repensar. Quando ele esteve no hospital, longe de sua mãe, ambos pareciam definhar. Foi seu reencontro que os fortaleceu a ambos, o bebê para que vingasse e se tornasse uma criança viva e curiosa, a mãe para que sorrisse e aguentasse o pavilhão, a dureza, o desterro. Seu filho era também o que os ligava concretamente a sua terra; era a ele que Bixima tinha que falar na língua de seus ancestrais e apresentar, através dela, o mundo do qual ele veio sem nunca ter chegado a conhecer. Era por ele que Bixima se sentia obrigada a estar bem e a tratar a doença que não havia. Quem vai contar a história para ele?, ela perguntava diante da terapeuta ocupacional que os acompanhava. Eu preciso ficar bem para contar para ele a história; eu preciso ficar bem para levar ele de volta. Não quero que ele seja escravo.

Para Bixima, ser escravo era não ter a própria história. Sua vida tinha o sentido do cuidado do filho, não como uma cria, mas como um homem que, ao nascer em circunstâncias tão adversas, já era uma história iniciada, uma história cujo contar era sua tarefa como mãe, ela a única que o poderia fazer.

João Cabral de Melo Neto diz, no trecho que segue, do surgimento da vida como eterna resposta esperançosa à adversidade.

\author{
E não há melhor resposta \\ que o espetáculo da vida: \\ vê-la desfiar seu fio, \\ que também se chama vida, \\ ver a fábrica que ela mesma, \\ teimosamente, se fabrica, \\ vê-la brotar como há pouco \\ em nova vida explodida; \\ mesmo quando é assim pequena \\ a explosão, como a ocorrida; \\ mesmo quando é uma explosão \\ como a de há pouco, franzina; \\ mesmo quando é a explosão
}


de uma vida severina.

(1994, p. 60)

Bixima, querendo preservar a possibilidade de contar para o filho a sua história, enfrenta o mesmo do poema. Mesmo que seja pequena e franzina, mesmo que a nova vida seja severina. Ela não quer que ele seja escravo, mais um entre tantos, sem escolha, sem história própria. A possibilidade de contar para o filho sua história, já presente quando falava com ele na língua ancestral, era a maneira como Bixima vivia, na prisão e no desterro, a liberdade. Ela transformava, assim, a vida de seu filho e a sua, em vidas que não fossem severinas, de uma pobreza genérica. Enfrentava o mesmo da adversidade e o mesmo do igual, contra o qual cada um, mãe e filho, podiam, no mundo, ser si próprios.

Tamanha era a força da história deles que conseguiram coisas muito improváveis, como a soltura da mãe para que a criança não ficasse num abrigo. A mãe Bixima, e não qualquer pessoa que fizesse o papel de mãe, era absolutamente necessária ao filho, e por isso até a lei cedeu. 0 milagre.

E tanta gente ficou de olhos molhados na despedida de Bixima e seu filho do CHSP. As colegas também presas, as agentes de segurança, a terapeuta ocupacional, a psiquiatra, a pediatra, a secretária da saúde mental, a diretora clínica do hospital. Bixima, seu filho e sua força. 


\section{NO LUGAR DE UMA CONCLUSÃO}

É possível experimentar a liberdade estando encarcerado?

No início de meu trabalho no CHSP, parecia-me que sim. Agora, que já há dois anos frequento aquele lugar, respondo que não, exceto de forma muito limitada mas aí já não seria liberdade. A resposta se deve não somente ao que pude observar a partir de quem está encarcerado, mas também ao que pude perceber em mim. Não somente à nitidez com a qual não vi verdadeiras experiências comunitárias, políticas, de alcance muito maior que elas mesmas, como toda ação. Mas também à transformação que se me foi ocorrendo, um otimismo ingênuo se esvaindo, uma disposição sempre pronta para olhar o outro abrandando, sumindo. Embruteci, eu também, na prisão.

Se ficaram ralos os contares acerca de Breno, de Damião, de Tomás e de Bixima, se permaneceram em silêncio todos os outros que eu poderia haver escrito, se deixei de falar de tantos homens e mulheres com os quais me deparei, isto foi não só porque o tempo de dissertar é curto mas principalmente porque eu não pude. Porque eu também vivi a privação do encontro, a privação da palavra do discurso, a privação da possibilidade de escrever histórias, a privação da liberdade. E a história mais escrita talvez tenha sido a que não se deu, a escrita da falta pela própria falta, pelo silêncio, pela ausência do que poderia ter sido dito.

Mas eu, uma pessoa insistente, creio que a falta da história é, de alguma maneira, também uma história. Por isto creio que, mesmo quando ela não se deu, não se dá e nunca se dará, a liberdade continua possível. Por isto vejo no molhado dos olhos de todos na despedida de Bixima o flamejar da liberdade, descerrada, fazendo comunhão entre todos os que ali estiveram. Ainda que a repercussão daquele momento para quem o presenciou tenha tido, que eu saiba, menor alcance do que teria sido possível porque não mobilizou as pessoas a agir, seja em que direção fosse. As presas continuaram presas, cuidando de seus filhos, as agentes de segurança continuaram abrindo e fechando os portões, a equipe de saúde continuou seus atendimentos, os homens das outras alas continuaram sem saber de nada. 
Talvez a família de Bixima, lá em Angola, já tenha notícias dela. Talvez ela ainda acredite estar doente.

Talvez alguém leia sobre ela aqui, ou sobre Tomás, ou Damião, ou Álvaro, ou Eduardo e se surpreenda com o fato de que as pessoas que são presas tem histórias próprias, que precisam ser escutadas. E talvez as consiga escutar, mesmo quando eu não as tenha podido dizer. Se isto se der, aí sim: eu terei escrito alguma coisa que tenha a ver com liberdade. 
BIBLIOGRAFIA

ALES BELLO, A. Fenomenologia e Ciências Humanas. Bauru: EDUSC, 2004.

ANDERS, Günther. Kafka: pró e contra. São Paulo: Perspectiva, 1969.

ARENDT, Hannah. "Trabalho, obra, ação". Tradução de Adriano Correia. Em: Cadernos de Ética e Filosofia Política 7, 2/2005, pp. 175-201.

A condição humana. Rio de Janeiro: Forense Universitária, 2007. Eichmann em Jerusalém. São Paulo: Companhia das Letras, 1999. Entre o passado e o futuro. São Paulo: Perspectiva, 2011.

BACHELARD, Gaston. A poética do espaço. São Paulo: Martins Fontes, 2005.

BARBATO JÚNIOR, Roberto. Direito informal e criminalidade: os códigos do cárcere e do tráfico. Campinas: Millenium, 2006.

BICUDO, M.A.V. \& MARTINS, J. A Pesquisa Qualitativa em Psicologia: Fundamentos e recursos básicos. São Paulo: Morais/Educ, 1989.

BOÉTIE, Etiéne de la. Discurso da servidão voluntária. São Paulo: Brasiliense, 1982.

CLINI, Maíra Mendes. As cores de Pastore: grafite arte vida. Dissertação (Mestrado Programa de Pós-graduação em psicologia. Área de concentração: Psicologia Social) Instituto de Psicologia da Universidade de São Paulo. São Paulo, 2010.

COETZEE, J. M. Disgrace. Londres: Vintage, 2009.

DOSTOIÉVSKI, Fiódor. Crime e castigo. São Paulo: Editora 34, 2001.

ÉSQUILO; SÓFOCLES. Rei Édipo; Antígone; Prometeu acorrentado. São Paulo: Ediouro, 2002.

FREITAS, Danielle Pisani. Daseinsanalyse e liberdade. In Daseinsanalyse/ Associação Brasileira de Daseinsanalyse No. 15/16 (2011). São Paulo: A Associação, 2011.

GOFFMAN, Erving. Manicômios, prisões e conventos. São Paulo: Perspectiva, 2013.

GONÇALVES FILHO, J. M. Humilhação social: humilhação política. In: Beatriz de Paula (org). Orientação à queixa escolar. 2a edição. São Paulo: Casa do Psicólogo, 2007. pp. 187-219. 
HEIDEGGER, M. A essência do fundamento. in Marcas do caminho.

Petrópolis, RJ: Vozes, 2008. pp. 134-188.

Seminários de Zollikon. São Paulo: EDUC; Petrópolis: Vozes, 2001.

Ser e Tempo. Petrópolis: Vozes, 2005.

Sobre a essência da verdade. Porto: Porto Editora, 1995.

KAFKA, Franz. Narrativas do espólio. São Paulo: Companhia das Letras, 2002.

LEVINAS, Emmanuel. Ética e infinito. Lisboa: Edições 70, 2013.

LISPECTOR, Clarice, SABINO, Fernando. Cartas perto do coração. $3^{\text {a }}$ edição. Rio de Janeiro: Record, 2001.

MELO NETO, João Cabral de. Morte e vida severina e outros poemas para vozes. Rio de Janeiro: Nova Fronteira, 1994.

NAFFAH NETO, Alfredo. Poder, vida e morte na situação de tortura: esboço de uma fenomenologia do terror. São Paulo: HUCITEC, 1985.

POMPEIA, João Augusto; SAPIENZA, Bilê Tatit. Os dois nascimentos do homem. Rio de Janeiro: Via Verita, 2011.

Na presença do sentido. São Paulo:

EDUC; Paulus, 2004.

SAFFI, Fabiana. A avaliação de terapia cognitivo-comportamental para prevenção de reincidência penitenciária. Dissertação (mestrado) - Faculdade de Medicina da Universidade de São Paulo. Departamento de Psiquiatria. São Paulo, 2009.

SAFRA, Gilberto. A po-ética na clínica contemporânea. Aparecida, SP: Ideias \& Letras, 2004.

SAINT-EXUPÉRY, Antoine de. Terra dos homens. Rio de Janeiro: Nova Fronteira, 2006.

SANTOS, Edna Teresinha dos. O fenômeno da prisonização (Uma experiência no Complexo Médico-Penal do Paraná). Monografia para a especialização em "Modalidades de Tratamento Penal e Gestão Prisional". Universidade Federal do Paraná. Curitiba, 2003.

STEIN, Edith. La estrutura de la persona humana. Madrid: Ed Bac, 2007.

STEINHARDT, Nicolae. O diário da felicidade. São Paulo: É Realizações, 2009. 
VALVERDE, Alexandre. Ruptura, Solidão e Desordem: Ensaio sobre Fenomenologia do Delírio. São Paulo: Editora Fap - UNIFESP, 2011.

\section{Sites acessados:}

Irmandade da Santa Casa da Misericórdia de São Paulo -

<http://www.santacasasp.org.br > ; acesso em março de 2013.

Secretaria de Administração Penitenciária - < http://www.sap.sp.gov.br > ; acesso em março de 2013.

Sistema Integrado de Informações Penitenciárias, InfoPen:

$<$ http://portal.mj.gov.br>; acesso em abril de 2013.

Tribunal de Justiça do Distrito Federal e dos Territórios - < http://www.tjdft.jus.br > acesso em 24/02/2014. 
ANEXOS 


\section{Termo de Consentimento Livre e Esclarecido}

\section{1 - DADOS DE IDENTIFICAÇÃO DO SUJEITO DA PESQUISA OU RESPONSÁVEL LEGAL}

1. NOME DO PACIENTE:

DOCUMENTO DE IDENTIDADE DATA DE NASCIMENTO:.............

ENDEREÇO:

BAIRRO: CIDADE:

CEP: TELEFONE: DDD(

2. RESPONSÁVEL LEGAL:

NATUREZA (grau de parentesco, tutor, curador etc.) DOCUMENTO DE IDENTIDADE: DATA DE NASCIMENTO:.............. ENDEREÇO:

BAIRRO: CIDADE:

CEP: TELEFONE: DDD( ..)

\section{II- DADOS SOBRE A PESQUISA CIENTÍFICA}

1. TÍTULO DA PESQUISA: Privação de liberdade: a vivência de suas diferentes formas no hospital penitenciário PESQUISADOR: Natalia Joelsas Timerman CARGO/FUNÇÃO: Médica psiquiatra INSCRIÇÃO NO CONSELHO REGIONAL: CRM SP 119772 UNIDADE DA UNIVERSIDADE DE SÃO PAULO: Instituto de Psicologia 2. AVALIAÇÃO DO RISCO DA PESQUISA: Risco mínimo 3. DURAÇÃO DA PESQUISA: 24 meses

\section{III- REGISTRO DAS EXPLICAÇÕES DO PESQUISADOR AO PACIENTE OU SEU REPRESENTANTE LEGAL SOBRE A PESQUISA:}

O propósito desta pesquisa científica é procurar compreender como as pessoas vivenciam (vivem e sentem em profundidade) o fato de apresentarem algum tipo de limitação, seja pelo fato de estarem na prisão, seja pelo fato de estarem doentes, e quais os sentidos e significações pessoais que dão para esses problemas. Para tanto, serão realizadas entrevistas, eventualmente divididas em duas vezes, cada uma podendo durar aproximadamente de uma a duas horas. Durante a entrevista serão feitas perguntas ao informante para se alcançar os objetivos da pesquisa.

Os registros feitos durante a entrevista não serão divulgados aos profissionais que trabalham nesta instituição nem terão qualquer influência legal em termos de aumento ou diminuição da pena de detenção, nem nenhum tipo de uso ou divulgação relacionado a julgamento penal, mas o relatório final, contendo citações anônimas, estará disponível 
para todos quando estiver concluído o estudo, inclusive para apresentação em encontros científicos e publicação em revistas especializadas.

Poderá não haver benefícios diretos ou imediatos para você enquanto entrevistado deste estudo, além da oportunidade de você poder falar de suas coisas, mas poderá haver mudanças nos cuidados dados aos pacientes e detentos após os profissionais de saúde e do sistema carcerário tomarem conhecimento das conclusões.

Este projeto foi aprovado pelo Comitê de Ética do Instituto de Psicologia da Universidade de São Paulo em 18 de fevereiro de 2013.

\section{IV- INFORMAÇÕES DE NOMES, ENDEREÇOS E TELEFONES DOS RESPONSÁVEIS PELO ACOMPANHAMENTO DA PESQUISA, PARA CONTATO EM CASO DE INTERCORRÊNCIAS CLÍNICAS E REAÇÕES ADVERSAS:}

Dadas as características do projeto, ocorrência de reações adversas não é esperada, mas caso isso ocorra entrar em contato no telefone 3581-3727 (setor de Saúde Mental do Centro Hospitalar do Sistema Penitenciário)

\section{V- CONSENTIMENTO PÓS-ESCLARECIDO}

Este TERMO é para certificar que eu, , concordo em participar na qualidade de voluntário do projeto científico acima mencionado. Por meio deste, dou permissão para ser eu entrevistado.

Estou ciente de que, ao término da pesquisa, os resultados serão divulgados, porém sem que meu nome apareça associado à pesquisa.

Estou ciente de que não haverá riscos imediatos para minha saúde resultante da participação na pesquisa nem qualquer alteração de pena de detenção relacionada a ela.

Estou ciente de que sou livre para recusar a dar resposta a determinadas questões durante as entrevistas, bem como para retirar meu consentimento e terminar minha participação a qualquer tempo sem penalidades e sem prejuízos aos atendimentos e tratamento que recebo.

Por fim, sei que terei a oportunidade para perguntar sobre qualquer questão que eu desejar, e que todas deverão ser respondidas a meu contento.

Este termo de consentimento livre e esclarecido foi elaborado em duas vias, sendo que, após assinadas, uma ficará com o pesquisador e outra com o sujeito da pesquisa.

Em caso de dúvidas quanto a este termo de consentimento e suas implicações, além da própria pesquisadora, é possível contatar o Comitê de Ética em Pesquisa com Seres Humanos do Insituto de Psicologia da Universidade de São Paulo: ceph.ip@usp.br; telefone/fax: (11) 3091-4182.

NOME:

ASSINATURA:

DATA: 


\section{IRMANDADE DA SANTA CASA DE MISERICÓRDIA DE SÃO PAULO}

\section{PARECER CONSUBSTANCIADO DO CEP}

\section{Elaborado pela Instituição Coparticipante}

\section{DADOS DO PROJETO DE PESQUISA}

Título da Pesquisa: Privação de liberdade: a vivência de suas diferentes formas no hospital penitenciário

Pesquisador: Natalia Joelsas Timerman

Área Temática:

Versão: 2

CAAE: 07311312.7 .0000 .5561

Instituição Proponente: INSTITUTO DE PSICOLOGIA ((USP))

Patrocinador Principal: Financiamento Próprio

\section{DADOS DO PARECER}

Número do Parecer: 273.045

Data da Relatoria: $13 / 05 / 2013$

\section{Apresentação do Projeto:}

Este trabalho é um projeto de Mestrado vinculado ao Departamento de Psicologia Clínica do Instituto de Psicologia da Universidade de São Paulo.

Ele pretende realizar uma aproximação fenomenológica das diferentes formas de se estar privado de liberdade dentro da prisão. Ele se inicia na experiência de atendimento, e suas consequentes reflexões, de três pacientes detentos no Centro Hospitalar do Sistema Penitenciário (CHSP), desde 2009 gerido por uma parceria entre a Secretaria de Estado da Saúde e a Irmandade da Santa Casa de Misericórdia de São Paulo. O pesquisador refere que A., com diagnóstico de câncer, através da maneira como ele oferecia a sua história já próxima do fim, revivia sua vida através dos novos sentidos que o contar lhe possibilitava, por exemplo quando falava da morte do pai, que ocorrera quando ele já estava preso, e por isso a qual ele não pudera acompanhar. Ele falava daquela morte com dor muito mais pungente que a dor de estar cotidianamente distanciado do mundo pelo fato de estar preso. Comecei a suspeitar de que, dentro da prisão, existem muitas formas de se estar preso; estar encarcerado era difícil, mais que pelo cotidiano restrito, pelo distanciamento dos grandes acontecimentos das pessoas queridas: seu nascimento e sua morte. W., o segundo paciente, escutava as perguntas que eu Ihe fazia em seu primeiro atendimento, parava, silenciava, às vezes gargalhava

Endereço: SANTA ISABEL

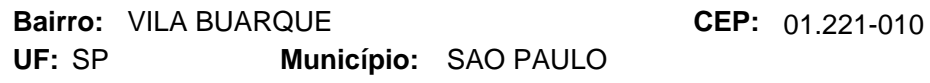




\section{IRMANDADE DA SANTA CASA DE MISERICÓRDIA DE SÃO PAULO}

Continuação do Parecer: 273.045

antes de responder, e a certa altura da nossa conversa ele me diz emocionado que nunca tinha falado nada daquilo para ninguém. Diante de mim, encontrava-se alguém atônito e maravilhado diante da descoberta da possibilidade de falar de si e que sentia o poder de narrar a própria vida na forma de uma história, possibilitando recolocar a

maneira como ele mesmo via a precariedade de sua existência. E., o terceiro dos pacientes, estava internado na ala psiquiátrica do CHSP e encontrava-se francamente psicótico. Pulava de uma ideia a outra, todas grandiosas. Um dia, ele me disse que era o Aladim, e me foi inevitável deixar escapar a mais sonora das gargalhadas. Ele riu junto, compreendendo e compreendido; e, para provar que era de verdade o Aladim, saiu pulando numa perna só, enquanto eu ria mais, junto com ele, que pulava e ria. De alguma maneira, E. estava me dizendo quem era naquele momento: um personagem de si mesmo, fictício, e anacrônico; e a minha gargalhada, pela própria espontaneidade, talvez o tenha liberado para ir mais longe e dizer-me mais de si e dos presos (e dos homens) através de seu gesto: alguém que tem uma perna a menos, erra o personagem que escolheu para a própria vida, mas consegue pular, gargalhando, absurdo entre aquelas paredes e grades, transbordando vida onde só deveria ser permitido definhar. E. estava preso, psicótico e internado; poderia se dizer que estava triplamente preso. No entanto, seu gesto absurdo, legitimado pelo absurdo da minha gargalhada, parecia livre. E. mostrava-me que o oposto ao aprisionamento não é necessariamente a liberdade, pois esta pode se presentificar mesmo quando se está encarcerado, existindo onde se der o que é humano no homem, segundo a concepção de liberdade de Hannah Arendt em A condição humana (2007) e em Entre o passado e o futuro (2011). Assim surgiu, somando-se ao que trouxeram as histórias de

A. e W. e seu contar, para mim, a indagação a respeito da relação do aprisionamento com a liberdade: de que forma estar encarcerado, preso, o que comumente se denomina como estar "privado de liberdade", verdadeiramente "priva" a liberdade? O que o aprisionamento, em suas diferentes manifestações, pode dizer a respeito da liberdade? É possível acercar-se da liberdade ontológica através da ôntica? Para tentar responder a essas questões, pretendo aproximar-me das diferentes maneiras de aprisionamento que se explicitam no hospital penitenciário através dos relatos das vivências dos próprios internos.

\section{Objetivo da Pesquisa:}

Realizar uma aproximação fenomenológica compreensiva do que vivem e como vivem os pacientes/detentos, em um hospital penitenciário, as diferentes maneiras de estar limitados em suas possibilidades, procurando estabelecer possíveis relações entre aprisionamentos no sentido de limitações de ser si-mesmo, e a liberdade.

Endereço: SANTA ISABEL

Bairro: VILA BUARQUE
UF: SP

Telefone: (11)2176-7689 Fax: (11)2176-7688 E-mail: eticamedbernadete@santacasasp.org.br 


\section{IRMANDADE DA SANTA CASA DE MISERICÓRDIA DE SÃO PAULO}

Continuação do Parecer: 273.045

\section{Avaliação dos Riscos e Benefícios:}

Há risco de que os conteúdos trazidos pelos pacientes nas entrevistas possam mobilizá-los emocionalmente, porém será oferecido espaço de acolhimento junto à pesquisadora na tentativa de dar respaldo a possíveis questões pessoais levantadas. Atentar-se-á especialmente ao trato e cuidados subsequentes com o detento hospitalizado psicótico, o detento hospitalizado com doença terminal, o detento hospitalizado com quadro

plégico e o detento hospitalizado na área segura da prisão, na tentativa de prevenir eventuais agravamentos dos atuais quadros psíco-clínicos dos mesmos.

\section{Comentários e Considerações sobre a Pesquisa:}

Os participantes podem beneficiar-se de contar a própria história pela possibilidade terapêutica que se dá no falar, e tecendo com ela uma possível narrativa da própria vida; de possíveis mudanças nos cuidados dados aos pacientes e detentos após os profissionais de saúde e do sistema carcerário tomarem conhecimento das conclusões; e de eventuais questionamentos que possam surgir, a partir dos resultados da pesquisa, a respeito das concepções de liberdade e de suas privações, questionamentos esses que podem suscitar alguma discussão acerca do encarceramento como punição e quem sabe até a revisão de políticas públicas.

\section{Considerações sobre os Termos de apresentação obrigatória:}

De acordo.

\section{Recomendações:}

Toda documentação do projeto apresentada ao CEP da Santa Casa de São Paulo, foi aprovada na reunião extraordinária realizada dia 15/05/2013.

Apresentar relatórios parciais e final do projeto. (modelo na página do CEP)

1ำ relatório deverá ser apresentado ao CEP via plataformabrasil em 15/11/2013.

\section{Conclusões ou Pendências e Lista de Inadequações:}

Aprovado.

\section{Situação do Parecer:}

Aprovado

\section{Necessita Apreciação da CONEP:}

Não

Endereço: SANTA ISABEL

Bairro: VILA BUARQUE

$\begin{array}{lcc}\text { UF: SP } & \text { Município: } & \text { SAO PAULO } \\ \text { Telefone: } & \text { (11)2176-7689 } & \text { Fax: }\end{array}$
CEP: $01.221-010$

E-mail: eticamedbernadete@santacasasp.org.br 


\section{IRMANDADE DA SANTA CASA \\ DE MISERICÓRDIA DE SÃO \\ PAULO}

Continuação do Parecer: 273.045

Considerações Finais a critério do CEP:

SAO PAULO, 15 de Maio de 2013

Assinador por:

Nelson Keiske Ono

(Coordenador) 


\section{INSTITUTO DE PSICOLOGIA DA UNIVERSIDADE DE SÃO}

\section{PARECER CONSUBSTANCIADO DO CEP}

\section{DADOS DO PROJETO DE PESQUISA}

Título da Pesquisa: Privação de liberdade: a vivência de suas diferentes formas no hospital penitenciário

Pesquisador: Natalia Joelsas Timerman

Área Temática:

Versão: 2

CAAE: 07311312.7.0000.5561

Instituição Proponente: INSTITUTO DE PSICOLOGIA ((USP))

Patrocinador Principal: Financiamento Próprio

\section{DADOS DO PARECER}

Número do Parecer: 198.896

Data da Relatoria: 26/11/2012

\section{Apresentação do Projeto:}

Conforme relatório anterior do $\mathrm{CEPH}$.

\section{Objetivo da Pesquisa:}

Conforme relatório anterior do $\mathrm{CEPH}$.

\section{Avaliação dos Riscos e Benefícios:}

Conforme relatório anterior do $\mathrm{CEPH}$.

\section{Comentários e Considerações sobre a Pesquisa:}

Conforme relatório anterior do $\mathrm{CEPH}$.

Considerações sobre os Termos de apresentação obrigatória:

Conforme relatório anterior do $\mathrm{CEPH}$.

\section{Recomendações:}

Recomenda-se a elaboração de termos de consentimento livre e esclarecido distintos para os casos de indivíduos com autonomia total e reduzida (casos de perturbação mental), reservando apenas para a última hipótese o espaço destinado à assinatura de responsável legal.

\section{Conclusões ou Pendências e Lista de Inadequações:}

Diante do etendimento das recomendações do parecer anterior, não há outras pendências a evidenciar, além da acima referida. 


\section{INSTITUTO DE PSICOLOGIA DA UNIVERSIDADE DE SÃO}

\section{Situação do Parecer:}

Aprovado

Necessita Apreciação da CONEP:

Não

Considerações Finais a critério do CEP:

Opina-se pela aprovação do projeto de pesquisa, solicitando-se à pesquisadora o envio de termos de consentimento livre e esclarecido distintos, conforme a recomendação acima exposta.

SAO PAULO, 18 de Fevereiro de 2013

Assinador por:

FRAULEIN VIDIGAL DE PAULA

(Coordenador) 